CHAPTER 3

\title{
Publisher of Books in Engineering and for Public Authorities (1877-1906)
}

$\mathrm{F}$ erdinand Springer began work in his father's firm in April Transitions 1871. All the signs indicate that there was an harmonious relationship not only between father and son, but also between them and their few employees. On January 1, 1872 Julius Springer made his son his partner. The father now felt he had been significantly relieved in his work and he wanted to give wings to his son's involvement in the firm. However, the decisive factor was Ferdinand's wish to get married. By making him a partner his father was giving him the means to set up his own household befitting his social position ${ }^{22}$ Marie Springer's worry, "how can two families live from the firm when so far it provided for only one?" [MS:104], soon vanished.

The table below shows that further progress was made during the six years of collaboration between father and son, by focusing the publishing programme. While the total number of titles

\begin{tabular}{|c|c|c|c|c|}
\hline \multirow[t]{2}{*}{ Subject area } & \multicolumn{2}{|c|}{$1867-1871$} & \multicolumn{2}{|c|}{$1872-1876$} \\
\hline & Titles & $\%$ & Titles & $\%$ \\
\hline Pharmacy & 15 & 9.3 & 16 & 8.0 \\
\hline Chemistry & 11 & 6.8 & 12 & 6.0 \\
\hline Engineering & 9 & 5.6 & 17 & 8.5 \\
\hline Biology & 3 & 1.9 & 7 & 3.5 \\
\hline Medicine & - & - & 1 & 0.5 \\
\hline Natural sciences (total) & 38 & 23.6 & 53 & 26.5 \\
\hline Forestry & 34 & 21.1 & 55 & 27.5 \\
\hline Law and political science & 21 & 13.0 & 10 & 5.0 \\
\hline Schoolbooks & 19 & 11.8 & 25 & 12.5 \\
\hline Politics & 17 & 10.6 & 16 & 8.0 \\
\hline Economics & 12 & 7.5 & 24 & 12.0 \\
\hline Various & 20 & 12.4 & 17 & 8.5 \\
\hline Total & 161 & 100.0 & 200 & 100.0 \\
\hline
\end{tabular}

List 2 Book production by subject area, 1867-1876 
increased by $25 \%$, the proportion of those on forestry increased more. The natural sciences were the second most important area in the publishing programme. The production of schoolbooks and publications in economics had also gone up. On the other hand, production of books on politics as well as law and political science had fallen. Theology, philology, belles lettres and travel books (also chess and music) have been included under "Various." The reduction of the number of publications in these previously quite significant areas is a further pointer to the gradual specialisation of the publishing programme.

At the time of Julius Springer's death the firm had only four employees. It will have been clear to Ferdinand that he would not be able to implement by himself his plans for the expansion of the business. His decision to have his brother join him in the firm must have been reached soon after their father's death, for it was in January 1878 that he proposed it to Fritz. ${ }^{23}$

The Springer Brothers $\Lambda$ fter obtaining his Abitur (graduation from secondary school) in 1869, Fritz Springer (1850-1944) first worked at the machine factory $\mathrm{Ohm} \& \mathrm{Co}$., with a view of becoming an engineer. After the Franco-German War (1870-1871), in which he volunteered as a Guards Rifleman, he returned to Ohm \& Co. for another two years. From 1873 to 1876 he studied at the Karlsruhe Polytechnic, which was then among the leading institutions in Germany for training in machine construction. Immediately after graduating Fritz was engaged by Louis Schwartzkopff ${ }^{24}$ who owned one of the leading machine factories. He did not even have time for a trip to Switzerland, which his father had promised him on finishing his studies.

As a student Fritz had already made himself fully familiar with the literature of his subject and had even subscribed to the English journal Engineer before he began his studies. At that time Great Britain was the leading country in engineering and there was no equivalent journal in Germany. In Schwartzkopff's construction office Fritz had always looked for the relevant literature whenever some new question or problem came up, and he often found that there was little on offer. Occasionally his father's firm would ask him to review a submitted manuscript. His brother's proposal therefore had some basis, particularly since Fritz was also very interested in the natural sciences, a subject in which Ferdinand Springer saw chances of expanding the firm's publishing programme. 


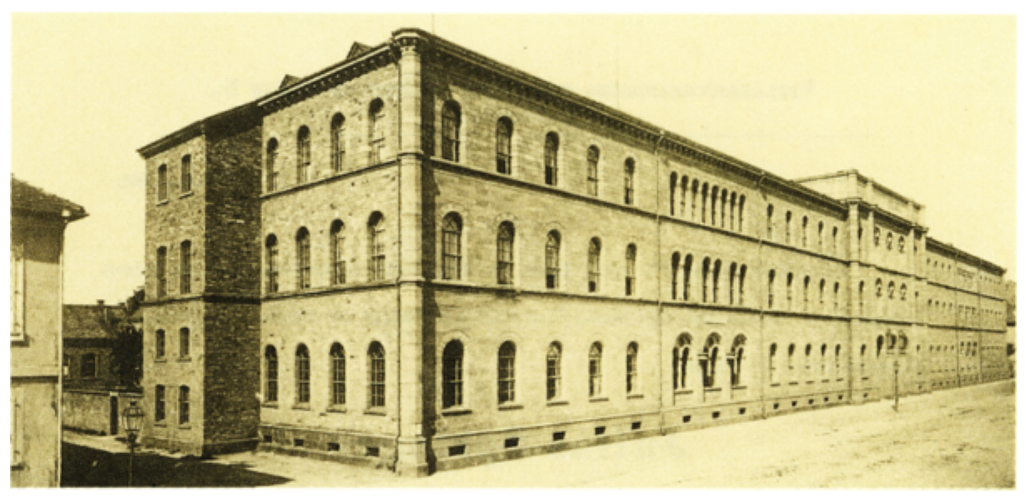

At his brother's suggestion Fritz worked as a voluntary assistant from February to July 1878 for Friedrich Volckmar (the firm's commission agent in Leipzig since its foundation) and the affiliated publishing house of C. F. Amelang. After that he went for six months to Altenburg (about $50 \mathrm{~km}$ south of Leipzig), as volunteer assistant at Pierer's Book Printing Company, which had been printer to the Springer firm since the 1850 os. The Pierer Company is, incidentally, the oldest uninterrupted supplier to Springer-Verlag. As an engineer Fritz was keenly interested in the technical aspects of book printing, so it was no accident that later on he looked after the firm's production department, in addition to all other administrative duties.

After Fritz had done a year's practical work, Ferdinand announced to the book trade that he had taken his brother Fritz into the firm on January 1, 1880 as "Public Partner." The two brothers worked together very harmoniously. As Ferdinand has not left any notes - he died unexpectedly in his 61st year - we quote here a description of the working relationship between the two brothers from Fritz's fragmentary memoirs [FS: 37]:

It was quite natural that, for the first few years after my joining the firm and despite my status as co-owner, its management was in the hands of my older brother who was much better trained in the book trade. This changed when we had a joint office on the ground floor; we both worked at a double writing desk and each would find out instantly from the other what was going on in the business. Over the years we quickly learned to work together. On going through the morning's post we were at once clear about any question that arose through new offers and similar matters.

The three sons of Julius Springer ${ }^{25}$ inherited one characteristic, probably from our father, which may be uncomfortable for some, but plays an important part in business matters, namely decided opinions, which we never concealed even in matters outside business. On our way to work... we would naturally talk about questions of business.
75 The Karlsruhe Polytechnic where Fritz Springer studied machine construction for six semesters. 
76 Circular (dated January 1, 1880) by the Julius Springer firm announcing that Fritz Springer had, like his brother Ferdinand while their father was still alive, become "co-participant" in the firm. From 1883 onwards he was listed in the Book-Trader Address Book as "coowner", as his brother had been called since 1872 .

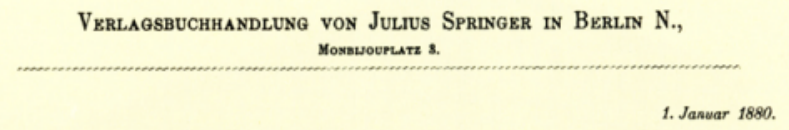

Hierdurch beehre ich mich, Thnen die Mittheilung zu machen, dass ich unterm heutigen Tage meinen jüngeren Bruder Herrn Fritz Springer als öffentlichen Theilnehmer in meine unter der Firma

\section{Julius Springer}

bestehende Verlagsbuchhandlung aufgenommen habe.

Ich bitte Sie Thre freundliche Gesinnungen und das Vertrauen, welches die Firms seit bald 40 Jahren im Deutschen Buchhandel geniesst, und welches die Besitzer derselben stets zu würdigen gewusst haben, auch dem neuen Mitgliede zu Theil werden zu lassen. Hochachtungsvoll und ergeben

Ferdinand Springer.

Herr Fritz Springer wird seicheen

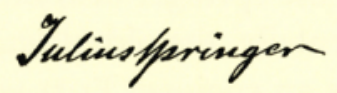

Almost always we would find that we were of one opinion. I do not recall that we ever had a quarrel, in particular over questions of business, new business activities or organisation of writings.

Quite naturally the focus of Fritz Springer's work was in the area of engineering, which at the time accounted for a good $20 \%$ of the total production. As Fritz was a gifted organiser, he was busy building up administration, for example, by setting up a specialised department, which was needed in the greatly expanding publishing house.

Ferdinand was the dominant of the two brothers, as Fritz always recognised. He had had a thorough training in publishing and retail bookselling in addition to six years with his father in the publishing business. But he also became active in his brother's field, as is evident from copies of many letters by his hand. What has been preserved of his correspondence shows that Fritz left to his older brother even decisions about offers, current correspondence and wording of contracts for projects that were really in his own area. Ferdinand was in charge. He had a very well developed managerial intuition and of the two brothers he was probably the more versatile in speech and on 
paper. In his contact with authors Ferdinand knew how to summarise the important points in a few sentences in a way that was persuasive.

$\mathrm{T}$ he 188 os saw the first great expansion of the publishing house with the founding or acquisition of numerous journals, which laid the broad foundations for future growth. Ferdinand had become convinced that the development of the firm and the expansion of its activities could be achieved only through journals. It is easier to react to advances in the sciences with journals than with books. Furthermore, it is easier to persuade an expert to write an article in a journal than a book.

When the forestry and pharmaceutical programmes were first started and developed, something - we now call it a synergy effect - became clear: journal editors can be persuaded to undertake book projects and they can also suggest potential authors. Where articles which have been submitted for publication in journals are too long, they can be published as monographs. Lastly, advertisements were becoming an important source of revenue, and the firm's own advertisements allowed cheap and selective promotion.

The periodicals founded or acquired in the 1880 s, some of them still published today, were pacemakers in the development of the firm during the following decades and provided decisive financial stability. This fact justifies a more extensive presentation of their founding or acquisition in the course of the following chapters.

The prerequisites for founding journals were particularly favourable at that time, because in the new German Empire numerous professional and vocational organisations were started whose members shared similar scientific and commercial interests. Despite separatist counter-currents the general direction was more and more towards Berlin, the headquarters of the imperial authorities, where various interest groups established themselves, existing Prussian institutions frequently providing their nucleus. Berlin also became a strong magnet, being the political centre for commerce, the banking system, the sciences and engineering. Springer-Verlag had a favourable starting position in the new imperial capital: its broad programme allowed it to recommend itself as publishing partner to the authorities and various associations.
Founding Years for Journals 
Collaboration with official bodies was more important and had a different significance in the years after the founding of the Empire than today. The institutions of the state at that time undertook research responsiblities, which in this century have been taken over by university institutes or other institutions (e.g. Kaiser-Wilhelm-Gesellschaft, later Max-Planck-Gesellschaft).

The polytechnics still directly served various trades. Their task was "to accord higher training for technical positions in the service of the state, the community or [significantly in third place!] industry...," as stated in the first paragraph of the statutes of the Technische Hochschule (Technical High School or College) founded in Charlottenburg in 1879.

In 1885 Springer became publisher on a commission basis (see p. 124) for the Imperial Public Health Department which was in charge, among other responsibilities, of laboratories for chemical, hygienic and bacterial examinations, in which the causes and conditions for the spread of common diseases and epidemics were investigated. After his first bacteriological discoveries Robert Koch was appointed to the Imperial Public Health Department where, in 1882, he discovered the cause of tuberculosis and, as leader of the department's expedition to Calcutta, of cholera.

The official authorities needed their own periodicals and regular series of books to publish their research findings. The publisher "on commission" of these publications also came into contact with the scientists and engineers in state employment. They submitted manuscripts of their own accord and many became Springer's authors. These connections often bore more fruit and were more lucrative than the official publications themselves, which were limited by what was supplied by administrative officials, most of whom knew little about publishing or market conditions.

The friendly connections which Julius Springer had with the liberals through his political activities proved to be of help in the expansion of his programme. His party colleagues were now

77 (See opposite page.) Leaflet announcing periodicals published by Springer (journals, quarterlies, calendars, and the Imperial Railway Timetable). The founding or acquisition of numerous specialist periodicals during the 1880 s was decisive for the firm's further development. members of many of the newly formed imperial authorities. In the six years in which Julius and his son worked together he had introduced Ferdinand to these circles. As has been mentioned, Julius was well acquainted with the General Postmaster, Heinrich Stephan; his deputy, Paul D. Fischer, was his friend. Rudolf Arnold Nieberding, the Reporting Councillor in the Imperial Chancellor's Office, was close to Springer, and Rudolf Delbrück, 


\title{
Periodische Erscheinungen
}

\author{
aus dem Verlage \\ von \\ Julius Springer in Berlin N., \\ Monbijouplatz 3.
}

\begin{tabular}{|c|c|}
\hline \\
\hline \multicolumn{2}{|c|}{$\begin{array}{l}\text { Elektrotechnisehe Zeitsehrift. } \\
\text { (Centralblatt für Elektrotechnik.) }\end{array}$} \\
\hline \multirow{2}{*}{\multicolumn{2}{|c|}{ 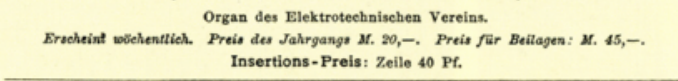 }} \\
\hline & \\
\hline \multirow{2}{*}{\multicolumn{2}{|c|}{ 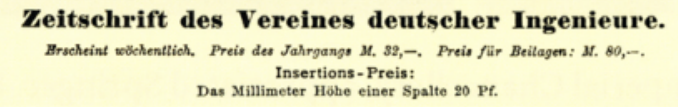 }} \\
\hline & \\
\hline \multirow{2}{*}{\multicolumn{2}{|c|}{ 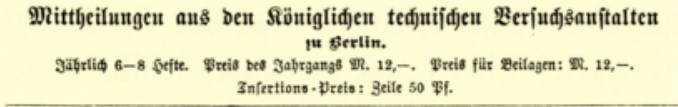 }} \\
\hline & \\
\hline \multirow{2}{*}{\multicolumn{2}{|c|}{ 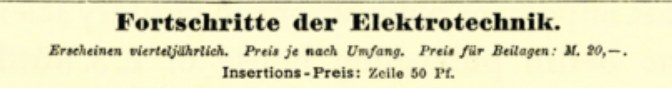 }} \\
\hline & \\
\hline \multirow{2}{*}{\multicolumn{2}{|c|}{ 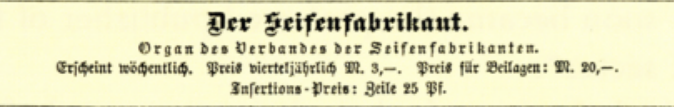 }} \\
\hline & \\
\hline \multirow{2}{*}{\multicolumn{2}{|c|}{ 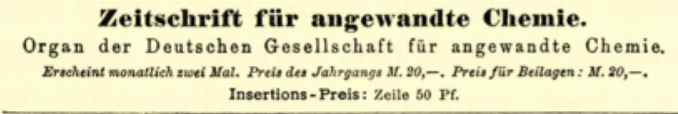 }} \\
\hline & \\
\hline \multirow{2}{*}{\multicolumn{2}{|c|}{ 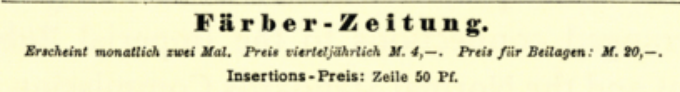 }} \\
\hline & \\
\hline \multicolumn{2}{|c|}{ Zeitschrift für Instrumentenkunde. } \\
\hline \multicolumn{2}{|c|}{$\begin{array}{c}\text { Erecheint monatlich. Preis det Jahrgangs, M. } 18,-. \text { Preit für Beilagen: M. } 20,-. \\
\text { Insertions-Preis: Zeile } 50 \text { Pe. }\end{array}$} \\
\hline \multicolumn{2}{|r|}{ Zeitschrift } \\
\hline \multicolumn{2}{|c|}{$\begin{array}{l}\text { Physikalisehen und Chemisehen Unterrieht. } \\
\text { Juhrieh } 6 \text { Hefe. Preis det Jalingangs } M \text {. } 10,- \text {. Preis für Beilagen : } M ., 20,- \text {. } \\
\text { Insertions - Preis: Zeile } 50 \mathrm{Pf} \text {. }\end{array}$} \\
\hline \multicolumn{2}{|c|}{ Pharmaceutisehe Zeitung. } \\
\hline \multicolumn{2}{|c|}{ 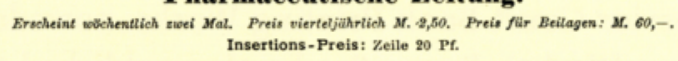 } \\
\hline \multicolumn{2}{|c|}{ Pharmacentisehe Centralhalle. } \\
\hline \multicolumn{2}{|c|}{ 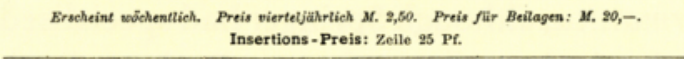 } \\
\hline \multicolumn{2}{|c|}{ 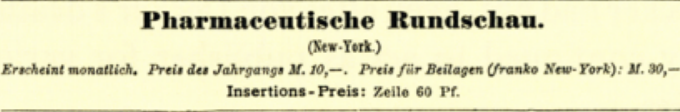 } \\
\hline \multicolumn{2}{|c|}{ 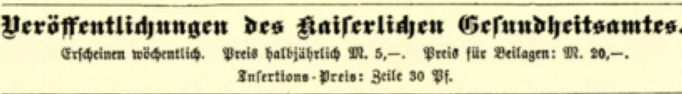 } \\
\hline \multicolumn{2}{|c|}{ Therapentische Monatshefte. } \\
\hline Erocheinen monatlich. & $\begin{array}{l}\text { Preis des Jahrgange 3r. 12,-, Preis für Beilagen : M. } 75,- \text {. } \\
\text { Insertions.Preis: Zeile } 75 \text { Pf. }\end{array}$ \\
\hline
\end{tabular}

\author{
Vierteljahresschrift \\ aber die \\ Fortschritte auf dem Gebiete \\ der \\ Chemie der Nahrungs- und Genussmittel.

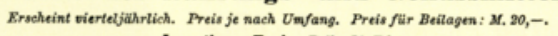 \\ Insertions - Preis: Zeile 50 PL.

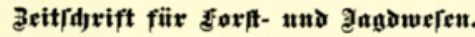 \\ Erí⿴囗十⺝⿱艹 \\ 3nfertions-Dreio: Beile 30 \$f.

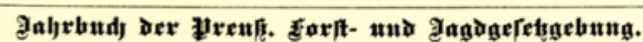

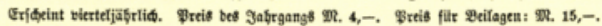 \\ 3nfertions-preto: Beile 30 \$r.

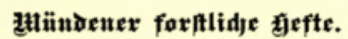 \\ Erífeinen in jwanglojen geften jäbrti申 zwei wac. \\ Drets ie nadt Ifmfang.

\begin{tabular}{|c|}
\hline 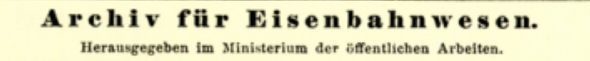 \\
\hline 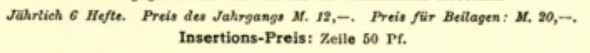 \\
\hline
\end{tabular}

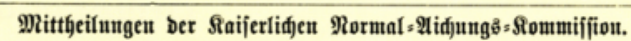

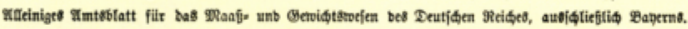

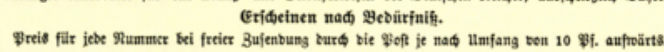
Preto für Meilagen: घr. 20,-,

Sofertions - pretio: Beile 50 qi.

\section{B. Fach-Kalender.}

Ing en i e ur - K a l ender.

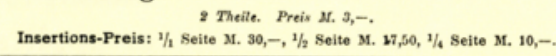

Chemiker - Kalender.

2 Theile. Preit M. s, -.

Insertions-Preis: $1 / 1$ Seite M. 20,-, 1/2 8eite M. 11,--, 1/4 Seite 3. 6,--.

Pharmaceutischer Kalender.

2 Theile. Preit $3.3,-$

Insertions-Preis: $1 / 1$ Seite $3.20,-, 1 / 2$ Seite $3 ., 11,-, 1 / 4$ Seite M. 6,-

\section{Forst- und Jagd-Kalender.}

2 Theile. Precio M. 4,-

Insertions-Preis: $1 / 1$ Seite M. 30,-, 1/2 Seite M. 17,50, 1/4 Seite M. $10-$

\section{C.}

Reiehs-Kursbueh.

Errecheint juhrlich acht Mat. Preit jeder Awagabe At, 2,-losertioss-Preis fir ein Jahr (acht Aasgaben):

$1 / 1$ Seite M. $300,-, 1 / 2$ Seite M. 160,-, 1/3 Seite M. $75,-, 1 / 10$ Seite M. $40,-$, 
78 Photograph of Rudolf (von) Delbrück (1817-1903), president of the Chancellor's Office and Bismarck's right-hand man between 1867 and 1876 , but later his opponent in economic questions. 79 Photograph of Robert Koch (1843-1910) who was appointed to the Imperial Public Health Office in 1880 , where he devoted himself to his bacteriological research.
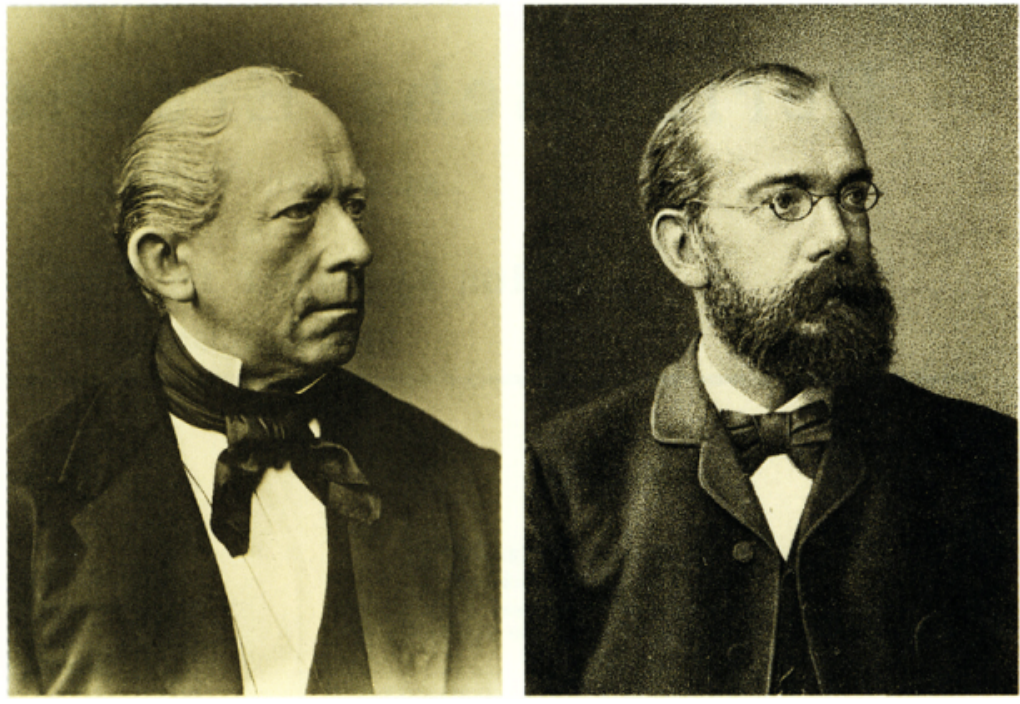

President of the Imperial Chancellery, appreciated Springer. He had coined the expression that Springer was the Civil-Mittler (Civilian Mittler) [FS:31].* This arose because, while it was a matter of course that important publications in military science appeared from the Berlin publishing house of E.S. Mittler, Springer similarly soon became the preferred publisher of the civilian or official sector*.

The contacts which Springer had made many years before were helpful in founding or taking over periodicals and also in obtaining numerous book projects. Rudolf Nieberding had, among others, arranged connections to the Imperial Public Health Department and the Normal Standards Commission, of which he was in charge. However the executive branch did not blindly follow ministerial advice, particularly as there were other applicants in Berlin who had good contacts with imperial departments. For example, the publisher R. von Decker was connected with the Königliche Geheime Oberhofbuchdruckerei (Royal Secret Superior Court Book Printing Works; nowadays the Federal Printing Works). From 1872 he also published the Pharmacopoea germanica, although Springer had specialised in this area, while Decker had not. Even after von Decker's death in 1877 , his company continued to act as publisher for various imperial authorities.

It was up to the financially stringent directors of the various ministries to place official publications, and they tended to

* The term "Civilian Middleman" thus had its basis in a pun on the firm's name (Mittler = middleman; mediator). 
Beleuchtung, Wasserversorgung und Kanalisation der Stadt Berlin. 1883.

Bericht über die Verwaltung der Feuerwehr und der Telegraphen von Berlin für das Jahr 1880. 1881.

Berlin und seine Eisenbahnen 1846-1896. Herausgegeben im Auftrage des Königl. Preußischen Ministers der öffentlichen Arbeiten. Two vols. 1896 .

Die Berliner Volkszählung vom 3. December 1861 . Two parts. 1863 .

Die Berliner Volkszählung vom 3. December 1864. 1866.

Blankenstein, Hermann und August Lindemann: Der ZentralVieh- und Schlachthof zu Berlin. Seine baulichen Anlagen und Betriebs-Einrichtungen. 1885.

Borrmann, Richard: Die Bau- und Kunstdenkmäler von Berlin. 1893.

Buchmann, Eduard: Die Entwicklung der Großen Berliner Straßenbahn und ihre Bedeutung für die Verkehrsentwicklung Berlins. 1910.

Dernburg, Friedrich: Berliner Geschichten. 1886.

Führer durch den städtischen Central-Vieh- und Schlachthof von Berlin. 1886.

Goldschmidt, Paul: Berlin in Geschichte und Gegenwart. 1910.

Die Große Berliner Straßenbahn 1871-1902. Denkschrift aus Anlaß der vollständigen Durchführung des elektromotorischen Betriebes. 1903 .
Guide médical de Berlin. Rédigé par le Dr. George Meyer par ordre du comité d'organisation pour le Xme congrès médical international. 1890 .

Gundlach, Wilhelm: Geschichte der Stadt Charlottenburg.

Two vols. 1905 .

Havestadt, Christian, und Max Contag: Süd-West-Kanal BerlinWannsee. 1883 .

Ingenieurwerke in und bei Berlin. Ed. by Alexander Herzberg and Diedrich Meyer. 1906.

Instruktionsbuch für die Berliner Feuerwehr. 1880.

Kemmann, Gustav: Die Berliner Elektricitätswerke bis Ende 1896. 1897.

- : Zur Eröffnung der elektrischen Hoch- und Untergrundbahn in Berlin. 1902

Lindemann, August: Die Markthallen Berlins. Ihre baulichen Anlagen und Betriebseinrichtungen. 1899.

Mamlock, G.: Wegweiser für Ärzte und Medizinstudierende in Berlin zur Benutzung von Unterstützungseinrichtungen, Stipendien, Wohlfahrtsanstalten usw. 1910.

Mattersdorf, Wilhelm: Die Berliner Straßenbahn-Verkehrsnot. 1908.

Medical Guide through Berlin. Prepared by Dr. George Meyer by order of the committee of organisation of the X. international medical congress. 1890.

Roeßler, Gustav: Gutachten über die Frage: Entspricht der elektrische Betrieb auf den Linien der Großen Berliner Straßenbahn durchweg den Anforderungen, welche nach dem gegenwärtigen Stande der Elektrotechnik an eine ordnungsmäßige und sichere Betriebsführung gestellt werden können? 1900.

Scabell, Carl Ludwig: Das Feuerlöschwesen Berlins. 1853.

-: Instructions-Buch und Exercier-Reglement für die Mannschaften der Feuerwehr von Berlin. 1854 .

Der Spreetunnel zwischen Stralau und Treptow bei Berlin. Ausgeführt in den Jahren 1895-1899. 1899.

Die Städteordnung von 1808 und die Stadt Berlin. Ed. by Paul Clauswitz. 1908.

Die städtischen Gaswerke in Berlin. 1847-1897. 1897.

Die Straßen-Brücken der Stadt Berlin. Edited by the Municipal Council, two vols. 1902.

Struve, H.: Reisetafel von Berlin. Eisenbahn-Zug-Verbindungen in Landkartenform von Berlin nach allen Ländern Europas, 1888.

Verzeichnis der Theilnehmer an der Stadtfernsprecheinrichtung in Berlin. 1892-1897.

Die Wohlfahrtseinrichtungen Berlins und seiner Vororte. 1899.

Zusammenstellung der polizeilichen Vorschriften für den Stadtkreis Berlin über die Errichtung von Baugerüsten, sowie Herstellung von Fahrbahnen zu Baustellen. 1888.

List 3 Books about Berlin in the publishing programme 
8o Photograph of Heinrich Stephan (1831-1897), from 1875 onwards Postmaster General of the German Empire. He organised the German postal system, proposed founding the World Postal Union, and played an important role in the introduction of the telephone in Germany.

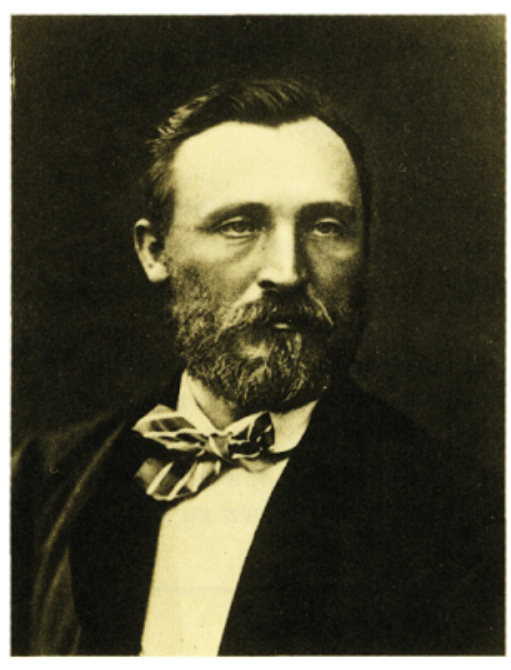

prefer the lowest offer. A newcomer had a chance only if he outbid his rivals with clever ideas and daring. Ferdinand Springer possessed these qualities in abundance, as he showed, for example, when he took over the Reichskursbuch (Imperial Railway Timetable).

The Imperial Timetable

Springer's parents had been friendly with the Under Secretary $\mathcal{S}$ of State Paul D. Fischer, and this friendship continued into the next generation. Fischer had connections with the book publishing trade through the Guttentags, his parents-in-law, and in his official capacity he was in charge of the Imperial Printing Works. One day he asked for Springer's advice. There was wide dissatisfaction with the Railway Timetable. The postal service was dissatisfied because sales were stagnant; R.von Decker as publisher objected that the list price had been fixed at 2 mark, without taking into account an increase in its size; and the book trade was disinterested because of the small discount. Finally, the public preferred the handier timetables brought out by private companies, especially Hendschel's Telegraph, the oldest and best established timetable.

Springer-Verlag proposed a more convenient format and improved distribution. This was to be financed by a discount of $40 \%$ and some exchange rights, as well as by more advertising. Springer's proposals were convincing and he, in turn, accepted the condition that the Imperial Printing Works were to continue the technical production at the contracted page price.

Immediately after taking over publication of the timetable in August 1880 the company started a wide promotional campaign. Twelve thousand placards were displayed at stations, in post offices and in bookshops, and 686 complimentary copies were sent to the press. Within a short time 40 bookshops in Germany, Austro-Hungary and Switzerland had agreed to set up depots from which other firms could order copies as needed. Station bookshops were given special sales conditions. A special Verzeichnis der in Berlin ankommenden und von Berlin abgehenden Eisenbahnzüge (List of train arrivals and departures in and from Berlin) was prepared for the leading Berlin newspapers (Die Vossische, National-Zeitung and Tribüne), for insertion in the Sunday editions at the beginning of the holiday season.

Advertisements were essential for financial success. As Springer had only limited experience in this area (with pharmacy and chemistry) and many branches of business were of interest to 


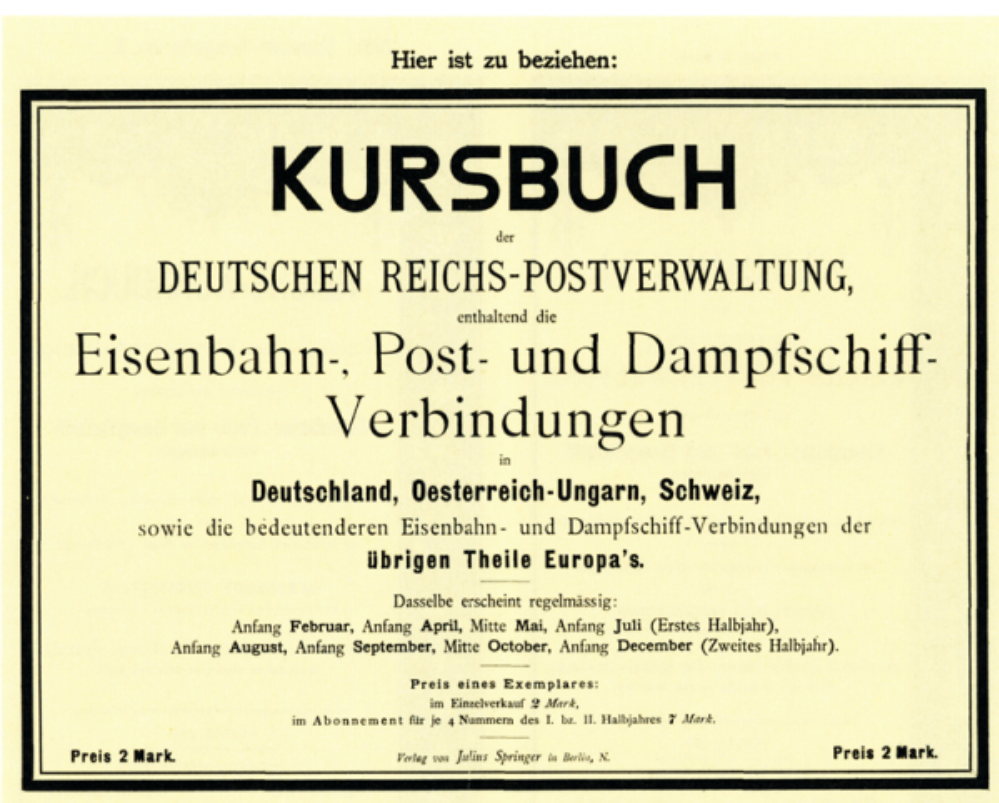

the travelling public and thus potential clients, a contract was signed with the Handelsgesellschaft RudolfMosse (Rudolf Mosse Trading Company)* which was to be responsible for the acquisition of advertising through its agencies, for a fee of $33 \frac{1 / 3}{3} \%$ of earnings or $5 \%$ for those sent to the publisher direct.

While the details of the four-page contract cannot be considered here, the advertising charges may be of some interest. With a print-run of at first 4000 copies per edition and eight editions annually, a whole-page advertisement cost 200 mark, half and quarter pages pro rata, and an eighth of a page 40 mark. If one wanted to advertise in only one edition the whole page cost 50 mark, and one-eighth 12 mark. These charges were usual at that time, but judged by today's prices and in relation to the print-run and cover price they were quite low.

After only a year Springer was proudly reporting the success of the firm's promotional efforts to the Imperial Post. But he asked for permission to change the cumbersome title of Kursbuch der Reichs-Postverwaltung (Timetable of the Imperial Postal Administration) to Reichs-Kursbuch (Imperial Timetable). The reason given for this change was that under its old name many perceived it to be a timetable mainly of trains of importance to the postal services. The change was made in

\footnotetext{
* Many years later "Mosse" was to become a large publishing empire of newspapers (e.g. Berliner Tageblatt), trade directories, etc.
}

81 Poster for the Timetable of the German Imperial Post Administration, containing rail, post and steamer connections in Germany, Austria-Hungary and Switzerland and the most important rail and steamer connections to the remaining parts of Europe. Before 1880 this timetable had been little more than official printing-matter. But Springer introduced it to the public at large through a wide promotional campaign, e.g. with 12,000 posters at stations, post offices and bookshops. 
82, 83 Covers of the Imperial Timetable. On the left: as it still looked in 1880 , as Timetable of the German Imperial Post Administration, giving rise to widespread misunderstanding that it con. tained merely connections of importance to the post; on the right: the cover of the re-named Imperial Timetable, as suggested by Springer.
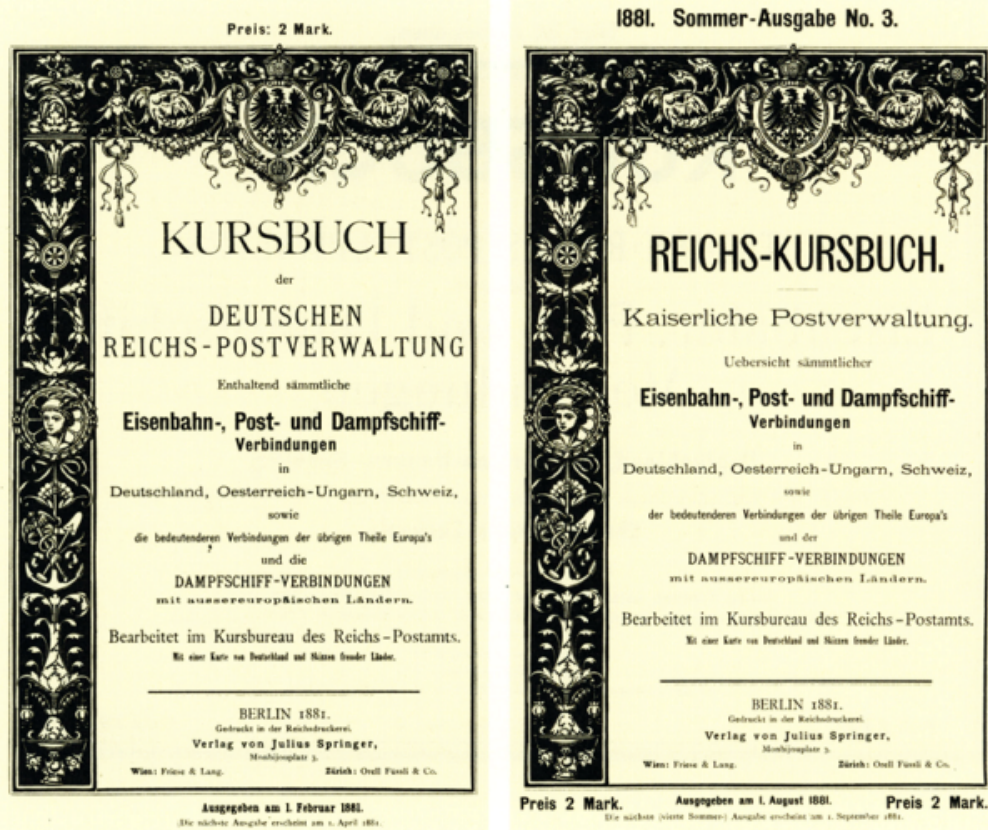

1881 and as a result the publication now acquired an "official" character, which helped sales.

When Springer took over the publishing on commission, each of the eight annual editions averaged 480 pages and was sold at a price of 2 mark per copy. Until the First World War the number of pages went up steadily, as the frequency of trains increased and new lines were added: 660 pages in 1888, 1000 in 1906 , and between 1100 and 1500 , depending on the season, in 1913. Although the rising number of advertisements was partly responsible for this increase in pages, $160-180$ per edition, the growing size meant that often the technical costs were higher than the firm's turnover. This deficit had to be covered by the proceeds from advertising. After years an increase in list price to 2.50 mark was finally agreed in 1908 .

In August 1914 the publishing calculations for the Timetable collapsed, because trains no longer ran at the listed times, having to meet the demands of the Imperial Army. Advertisements, which so far had made any kind of profit-bringing calculation possible, ceased almost completely during the war years of deprivation (see p. 225). After the war Springer-Verlag renounced any renewal of the contract. When the Imperial Railways again probed for renewal at the beginning of the economic crisis, it was declined. Springer was no longer interested, but the firm kept the distribution rights until 1944. 
$\mathrm{E}$ ven in his first few years as a publisher Julius Springer had brought out a few engineering books. There is, however, no evidence that he intended to specialise in this area, any more than any other publishing house. In 1850 only 34 engineering books were brought out in the German-speaking countries, spread among 24 publishers, Vieweg of Braunschweig and Cotta of Stuttgart the leading ones with four and three books, respectively. Clearly there had been no concentration yet. Springer only showed more interest in technical publications from 1858 onwards, i. e. after he had sold the bookshop. From that year at least one title, but never more than three, would appear annually - until 1871, when Ferdinand had become a partner. The numbers increased further with Fritz joining the firm.

The economic hegemony of Prussia had strengthened its military and political position and had thus significantly advanced unification of the German states. Berlin, now capital of the unified German Empire and seat of large, steadily growing enterprises in the metal and electrotechnical industry, offered many promising opportunities for a publisher of engineering titles. In addition, the Technical High School in Charlottenburg, which opened in 1880 , was soon likely to provide authors and advisers. Fritz Springer, the new partner, was a well-informed person to handle these contacts.

The proportion of technical books among the total production steadily grew by $14 \%$ in the first decade, $1878-1887$, after Ferdinand's son had taken over. It increased to $18.6 \%$ in the following decades and to nearly a third between 1898 and 1906 .

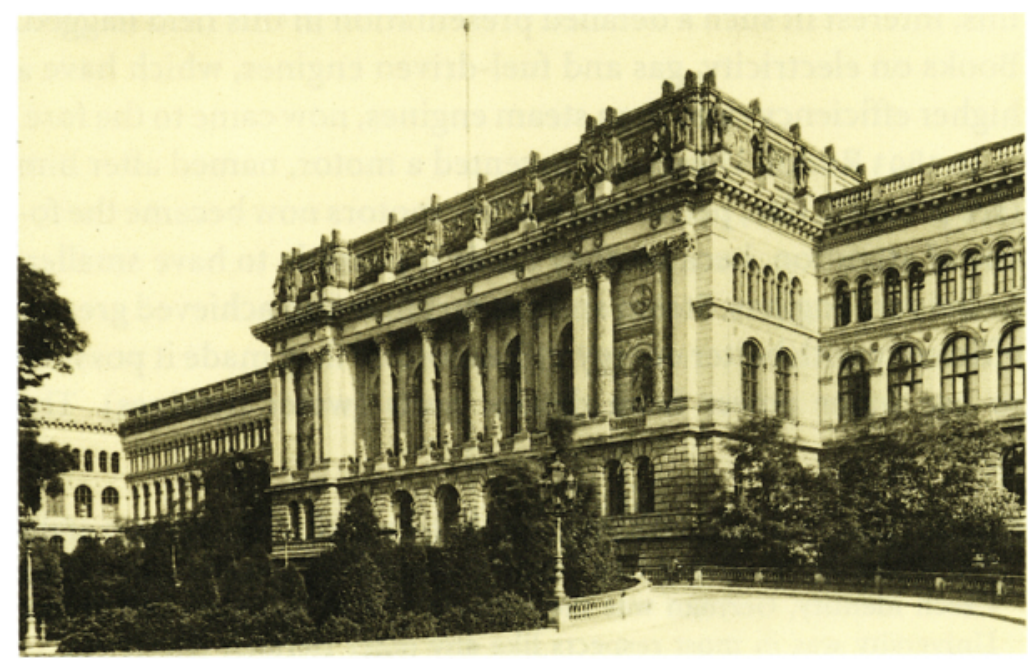

84 Photograph of the main entrance of the Technical High School in Charlottenburg, finished in 1880 . At that time Charlottenburg was an independent city, at the edge of Berlin.

\section{Publisher \\ of Engineering Books}




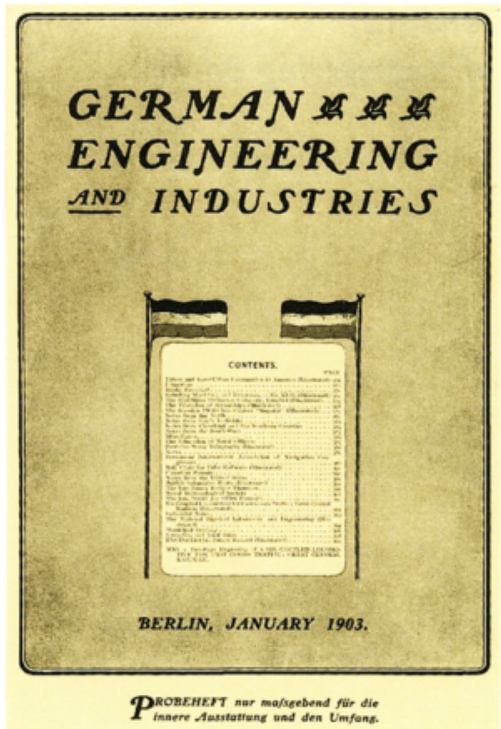

85 Cover page of the English-language engineering journal planned by Springer in 1903, in collaboration with German engineering organisations, to promote German exports. It should have been published monthly from 1904 onwards, consisting of eight to ten sheets and costing 16 marks (or 4 dollars). Although industry and government were very interested in the project, there were only a few firms ready to support it financially.
The multi-faceted nature of this list, 347 titles between 1898 and 1906 , is impressively shown in the table on p.160.

For thirty years forestry and agriculture had been Springer's strongest publishing area, but for the next three decades engineering was unchallenged as the leading one. By 1892 industrial production had become Germany's outstanding economic sector. The horse-power generated indicates the scale of the development, with 947 million in 1875, 3350 million in 1895, and reaching 7998 million in 1907 [HofFMANN: 264]. A smilar growth took place in metal production, which doubled between 1878 and 1889 , doubling again to 1904 and then to 1913 , i. e. an eight-fold increase over nearly 40 years. Many similar examples could be given.

Springer-Verlag responded to this development with an everbroader programme, which also demonstrates the technical advances of those years. At first, books on steam engines predominated. For example, Emil Blaha, lecturer at the Imperial and Royal Austro-German Polytechnic in Prague*, with whom the firm had close contacts, published in 1878 Die Steuerung der Dampfmaschinen (The Control of Steam Engines), which was reprinted in 1885 and again, revised and enlarged, in 1890 . It was also translated into English and Italian. When the need for a new edition arose in 1894, its author felt unable to update it, because he was no longer working in the field. Carl Leist, who became the editor, quickly recognised the book's weaknesses and, through contacts with manufacturers of steam engines, both in Germany and abroad, brought the book up-to-date by including the latest technology. This involved increasing its size from 218 to 768 pages and further, with the 5 th edition (1905), to 958 pages. After this, interest in such a detailed presentation in this field flagged. Books on electricity, gas and fuel-driven engines, which have a higher efficiency ratio than steam engines, now came to the fore.

In 1893 Rudolf Diesel had invented a motor, named after him (see p. 109 f.). Gas, petrol and electric motors now became the focus of attention, because they made it possible to have smaller, individual engines. Steam and gas turbines also achieved greater efficiency with better energy utilisation, or they made it possible to use water power from distant parts (water turbines). The

\footnotetext{
* At that time Bohemia, with Prague as its central city, was still part of the Habsburg Austro-Hungarian Empire. Despite an ancient and strong Czech identity, German was the region's official language and Prague University was in most respects like any other German university.
} 


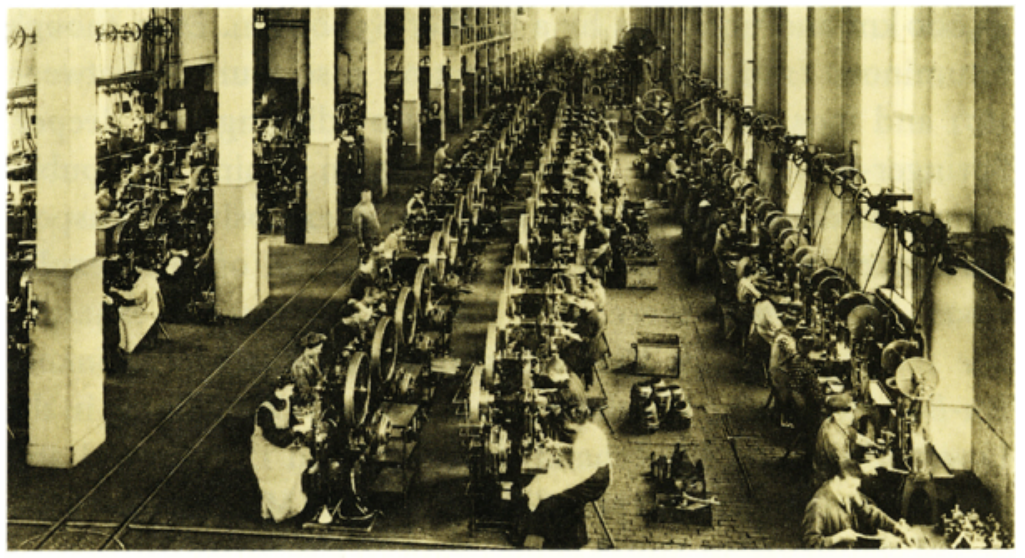

Paris World Fair of 1900 also provided an exhibition of turbine construction: Springer published a book on it. The first edition of Die Dampfturbine (The Steam Turbine) by Aurel Stodola was published in 1903. It was to become a standard work and a great success for Springer-Verlag (see p.112f.).

The first machine tools had already been constructed at the end of the sixteenth century, but their precision left much to be desired. By combining them with steam engines they became more efficient in the course of the nineteenth century, but their use did not become universal until the last quarter of that century. American design engineers were leading in this field, because the American system of manufacture was based on uniform and at the same time highly precise manufacture of large series (e.g. the turning lathe constructed by C. M. Spencer in 1873). Their leading position gave Springer reason to publish a report on Die Werkzeugmaschinen auf der Weltausstellung in Chicago 1893 (The Machine Tools at the 1893 Chicago World Fair), which appeared a few months after the Fair. The spread of machine tools increased further, because steam engines with extensive transmission systems requiring a high power output were no longer needed, small motors now providing individual power sources. Machine tools thus became achievable items for small enterprises and helped them to compete once more with large companies. In addition to smaller publications, in 1900/01 Springer published the 1000-page book on Die Werkzeugmachinen (Machine Tools) by Hermann Fischer.

The demand for coal grew steadily. Industry needed it to generate gas and electricity, for the growing merchant navy and the fleet, as well as for the expanding railway network. The latter increased between 1870 and 1890 from about 19,000 to
86 Photograph of the stamping press room at the AEG ("General Electricity Company") in Berlin, around 1907. Individual electric motors are being used at the work places in the middle, while at the windows one can see the transmission belts, driven by separate steam engines (not shown).

87 Cover page of the catalogue which lists the exhibits (models and drawings) of the German industry at the 1893 Chicago World Fair.

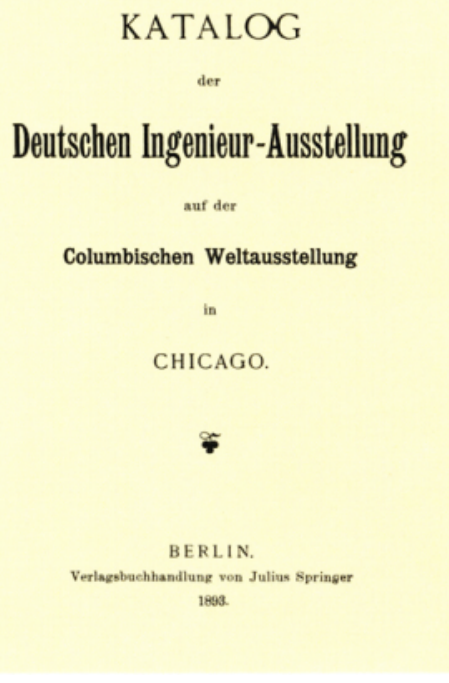


$43,000 \mathrm{~km}$ and until 1913 by a further $63,000 \mathrm{~km}$. Even though bituminous (mineral) coal production rose fourfold between 1871 and 1905 , this was possible only by digging ever deeper. Springer-Verlag met the need for books on mining with publications on deep-drilling technology, use of explosives, transport machinery, pumping systems and prevention of mine explosions. In addition there were large works on, for example, Die Entwicklung des Niederrheinisch-Westfälischen Steinkohlen-Bergbaues (The Development of Mineral Coal Mining in the Lower Rhine and Westphalia) (1902-1905 in 12 volumes) and Steinkohlenbergbau des preußischen Staates (Mineral Coal Mining of the Prussian State) (1904-1906 in six parts).

Zeitschrift des Vereines Deutscher Ingenieure (Journal of the Society of German Engineers)
$S_{\mathrm{p}}^{\mathrm{p}}$ pringer needed a journal in engineering to develop and complement his book programme. His attempts with the Jahresbericht über die Fortschritte der mechanischen Technik und Technologie (Annual on the Advances in Mechanical Engineering and Technology), published from 1861 to 1867 , and the Allgemeine deutsche polytechnische Zeitung (General German Polytechnic Newspaper) from 1873 to 1877 both failed. Their editor, Hermann Grothe, who had also written books about the textile industry, had not managed to assemble a group of qualified coworkers. Admittedly, this was rather difficult, practising engineers not being interested in working on a journal. As Fritz Springer mentioned, "In Germany [engineering] practitioners were shy about putting themselves forward. They were worried that they would be scolded by professors at the High Schools (Colleges)...." [FS: 23]. Yet these senior teachers were difficult to recruit as collaborators.

Founding a new journal would therefore be rather difficult, particularly as there was already the Zeitschrift des Vereines Deutscher Ingenieure (Journal of the Society of German Engineers), a society journal that went to its 4000 members. Yet there was some dissatisfaction with the journal, as Fritz Springer had learned and could himself confirm as a member of the society. The main complaint was that the journal did not appear regularly and was not practical enough. Furthermore, the society wanted a greater share of the profits.

Springer was not alone in offering to publish the journal on a commission basis. The Polytechnic Bookshop Albert Seydel in Berlin seemed to have a better chance because of its owner's long-standing contacts. On the other hand, Springer's offer of 


\section{ZEITSCHRIFT}

DES

\section{VEREINES DEUTSCHER INGENIEURE.}

Redacteur:

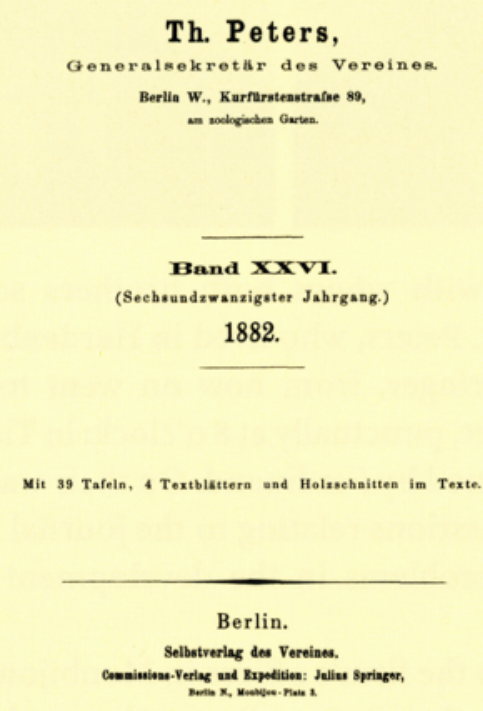

$\mathbf{8 8}$ Cover of the Zeitschrift des Vereines Deutscher Ingenieure (Journal of the Society of German Engineers), for which Springer had become the publisher "on commission", against fierce competition. The firm achieved an increase in subscriptions from 4500 to 24,500 over a period of 25 years.

guaranteed profit payments was the better. After a preliminary decision had been made in favour of his competitor, Springer increased his offer when he happened to meet the society's authorised representative, Franz Grashof, under whom he had studied in Karlsruhe: he raised the guaranteed share of advertising income to 24,000 mark, $20 \%$ more than the journal's profit in the preceding year. In addition, he agreed to a surety of 50,000 mark. As a result of this offer, far above that of the competition, Springer obtained agreement to publish the journal from January 1, 1882 (vol. 26) onward.

The journal was to be of the greatest importance in the further development of the firm and particularly of its engineering list. Advertising grew especially well. This was perhaps helped by charging for space by the millimetre - as is now the universal practice - and not, as before, by line of a particular type size. The society's new managing director and the journal's editor was 
89 Photograph of Franz Grashof (1826-1883), one of the co-founders, in 1856 , of the Society of German Engineers. In 1863 he was appointed to a chair at the Karlsruhe Polytechnic, in succession to Redtenbacher. Fritz Springer attended his lectures there. Springer acquired the journal of the Association (see Fig. 88) thanks to Grashofs good offices. 91 Theodor Peters (1841-1908). In 1881 he was appointed Secretary (later Director) of the Society of German Engineers. He was also Editor of the Society's journal and successfully adapted it to the rapidly changing world of engineering.

90 Numerous important articles, which had first appeared in the engineering journal, were later published separately by Springer, often in greatly expanded versions. In 1889 Barkhausen published an article about the Firth of Forth bridge which contained nine lithographic tables, one of which had the illustration reproduced here.
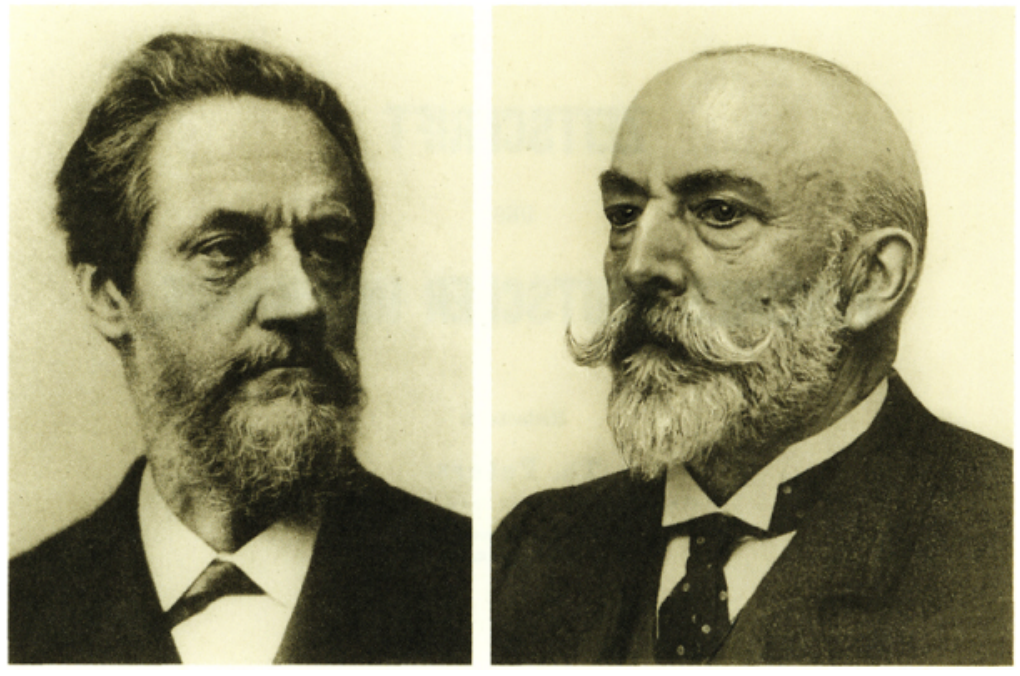

Theodor Peters with whom both brothers soon established friendly relations. Peters, who lived in Hardenberg Strasse next door to Fritz Springer, from now on went to work with his publishing partner, punctually at 8 o'clock: in Tiergarten Strasse they would be joined by Ferdinand. On their walk together they would discuss questions relating to the journal and the society, as well general problems in the development of engineering [FS: 25].

The distance to the firm's offices in Monbijouplatz was about $5 \mathrm{~km}$. This meant that their walk together took about an hour (occasionally they will have gone by hackney cab). At the Unter den Linden, the broad avenue in the centre of Berlin, Peters will have turned into the Charlottenstrasse where the Society of German Engineers had its headquarters. The three would write to each other only when new conditions in the contract had to be agreed, something which happened every few years as the journal became ever more successful. While it had 4500 subscribers in 1880 , the number had increased to 24,500 by 1906 . Its size grew from 400 pages annually to about 2400 in 1912 . The society's profits rose from 24,000 to 576,000 mark between 1882 and $1906 .{ }^{26}$

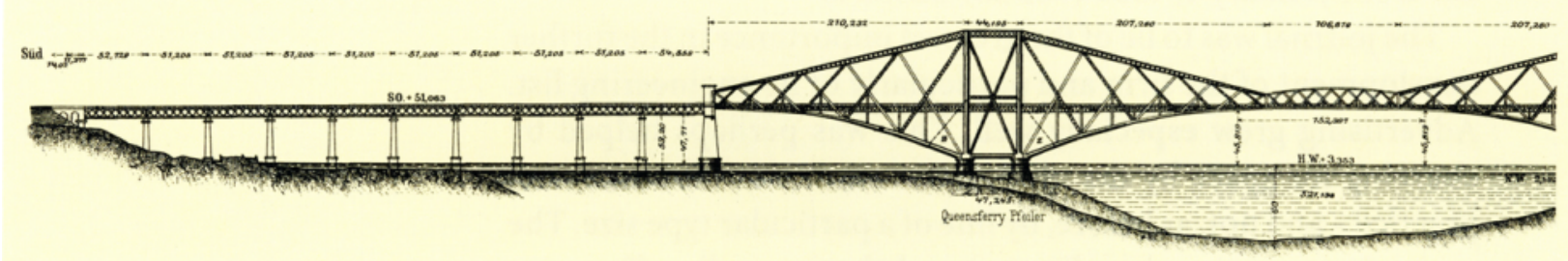


At the request of the society, Springer-Verlag took over "the [Society's] entire business and financial direction for a fee of 1000 mark annually. For this sum they looked after subscription payments, the issue of membership cards, payment to suppliers, officials etc., in response to directives from the society, the accounts of the local branches of the society, attending to the membership list, any related correspondence etc." This required considerable work, which was not really covered by the 1000 mark. But the firm established direct contact with all the society's members, who not only paid their contributions or arranged for advertisements with Springer-Verlag, but also ordered books from them. The resulting direct sales of a considerable number of books were to play a part in the discussions about reforms which were later to take place in the Börsenverein (see p. $142 \mathrm{f}$.).

Other journals in the field of engineering founded at that time included the Zeitschrift für Instrumentenkunde (Journal for the Study of Instruments), which was published from 1881 to 1941, Mitteilungen aus den königlichen technischen Versuchsanstalten (Reports from the Royal Technical Research Institutions), from 1883 to 1943, and Mitteilungen der Kaiserlichen NormalAichungs-Kommission (Reports of the Imperial Normal Standards Commission) from 1886 to 1931.

$\mathrm{I}^{\mathrm{s}}$

$\mathrm{n}$ the early 1860 s Springer had begun to publish books on electromagnetism by Julius Dub and others on technical aspects of telegraphy (Carl Grawinkel, Carl Alfred Nystrom, Joseph Sack and Karl Eduard Zetzsche), but it was not until the last quarter of the nineteenth century that electrical engineering became a leading part of the firm's programme. Elektrotechnische Zeitschrift (Electrical Engineering Journal), which Springer published from 1880 , became the leading periodical in the field. It had important consequences for the development of a publishing programme, as will be presented further (see p. 104 f.).

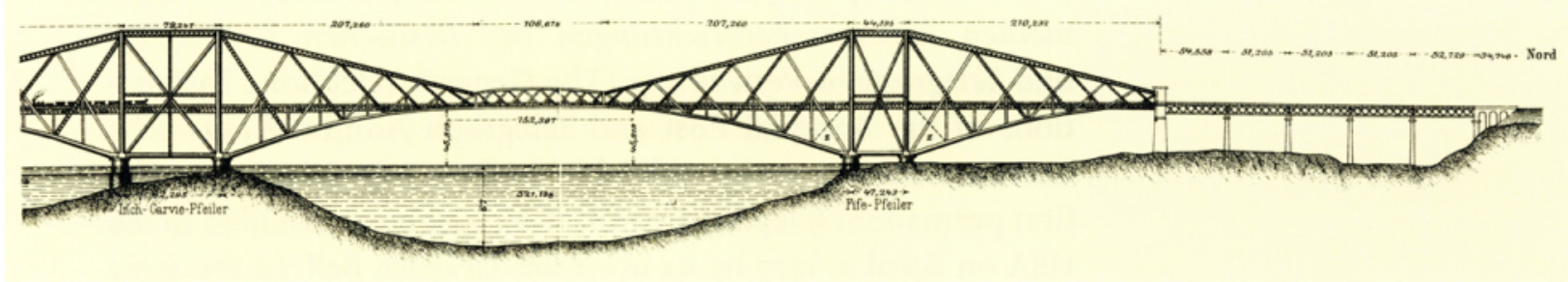


92 Photograph of the main entrance to the Electrotechnical Exhibition in Frankfurt from April 16 to October 19, 1891. Its main purpose was to demonstrate the advantages of the three different and competing systems of current (direct, alternating, three-phase). The latter was most dramatically demonstrated by the transmission of a 15,000 volt current from Lauffen to Frankfurt $(175 \mathrm{~km})$. It was the beginning of a development which led directly to today's European Power Transmission Network.

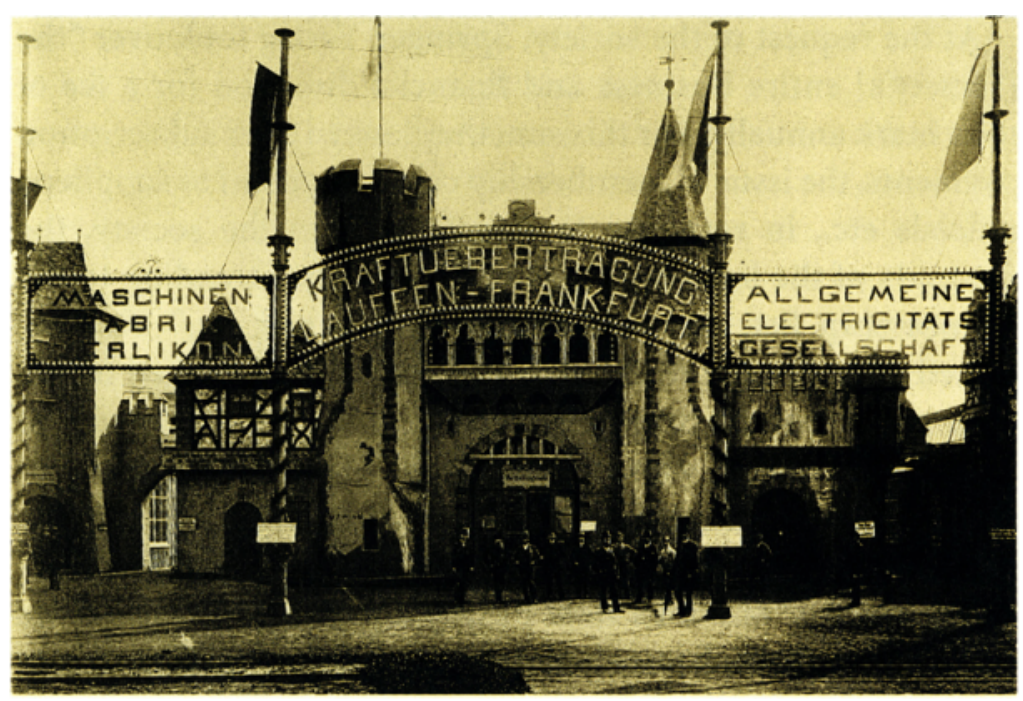

Under Fritz Springer's direction electrical engineering became the most important subject within the technology programme. Within three decades a total of 192 books appeared, some of them very large monographs, while others were textbooks, practice books, construction guidelines, instruction manuals, and no fewer than 25 soft-cover booklets on essential safety regulations. An ever-growing proportion of books was on generators, storage batteries, condensors, transformers etc.

The first German power station was opened in Berlin in 1881. When transformers had been built it was possible to transmit electrical power over long distances without significant loss, and electricity became the universal source of energy. The first cost-effective long-distance transmission took place in 1891, over a length of $175 \mathrm{~km}$, from Lauffen on the Neckar to Frankfurt on the Main, beginning the era of overland power supply: Springer-Verlag took part in it with appropriate publications.

Thanks to his excellent connections with the Imperial Post Office Springer had started to publish books on telephony very early in its development. An official Geschichte und Entwicklung des elektrischen Fernsprechwesens (History and Development of Electrical Telephony) appeared in 1880 and, in 1882, Die allgemeinen Fernsprecheinrichtungen der Deutschen Reichs-Post und Telegraphen-Verwaltung (The General Telephone Installations of the Imperial Post and Telegraph Administration) by Carl Grawinkel, a senior official in the Post Administration. The first permanent telephone connection had been installed in the USA on April 4, 1877 by its inventor, Graham Bell. In the same 


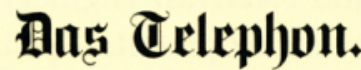

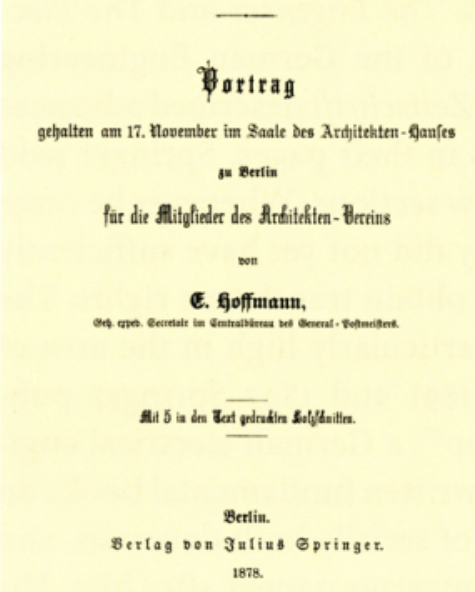

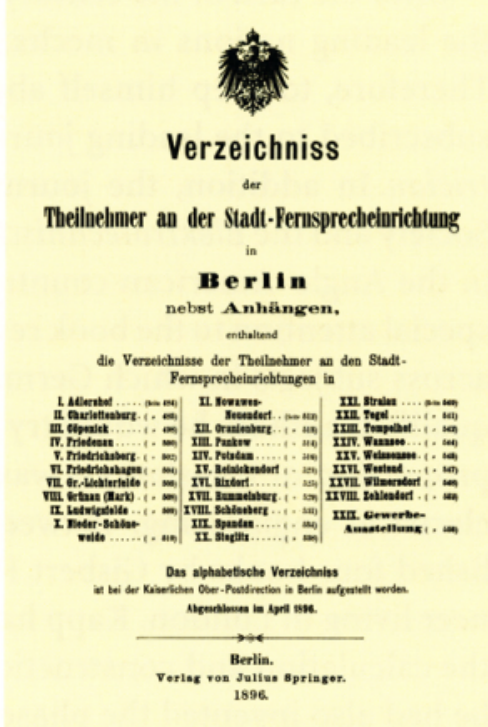

93 Title page of the printed version of a talk about the telephone, given by Ernst Hoffmann, Heinrich Stephan's secretary. It was in the subsequent discussion (which was printed together with the talk) that he made the suggestion to call the "Telephone" Ferntöner or Fernsprecher in Germany [the latter term in fact remains in common use to this day]. 94 Title page of the first telephone book of Berlin and surrounding communities (which are listed in front), of which Springer was the publisher between 1892 and 1897.

year Heinrich Stephan had, after successful trials with two instruments, called for preparations towards the introduction of the telephone in the German Empire. The Berlin Fernsprechvermittlungsamt (Telephone Connection Office) was opened in January 1881. The publishing company of Julius Springer was listed, as No. 559, in the first Berlin telephone directory in 1882 . In fact, Springer became its publisher from 1892 to 1897 , adding to it Part II, a listing by profession and business, thus planting the seed of our current businesses and services directories. In addition the firm brought out, in a third part, paid advertisements by companies. The publisher charged 100 mark for the whole page and 40 mark for a quarter page; naturally, Springer took the opportunity to advertise his own books of general interest in its pages.

There was a remarkable number of publications on behalf of large firms within the mechanical and electrical engineering industries. These included instruction books for the installation and use of their products for Siemens, the German Edison Company (founded in 1883; renamed AEG [Allgemeine ElektrizitätsGesellschaft] in 1887) and especially Brown Boveri \& Co. These firms had in-house engineering experts (they would not have wanted outsiders to be let into construction secrets), but they did not want to be bothered with such work. Furthermore, it seemed more professional for a well-known publisher to bring out these books under his own name. 


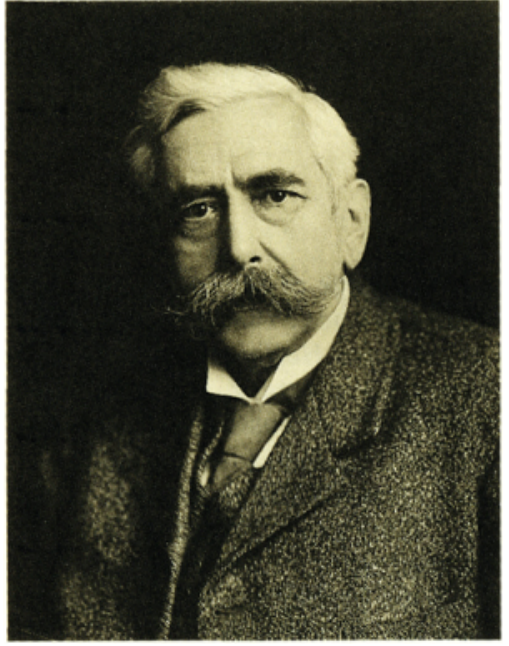

95 Gisbert Kapp (1858-1922), one of the most successful of Springer's specialist authors in the area of electrical engineering. He was secretary-general of the Verband (Union) Deutscher Elektrotechniker and the editor of the Elektrotechnische Zeitschrift from 1894 until 1905.
Until the turn of the century the USA and Great Britain were the leading nations in mechanical and electrical engineering. Therefore, to keep himself abreast of developments, Springer subscribed to the leading journals The Engineer and The Electrician. In addition, the journals of the German Engineering Society and the Elektrotechnische Zeitschrift described advances in the Anglo-American countries in their pages. Springer paid special attention to the book review sections. Whenever he came across subjects in which Germany did not yet have sufficiently qualified authors he would try to obtain translation rights. The proportion of translations was particularly high in the area of electrical engineering. Between 1891 and 1897 Springer published four books by Gisbert Kapp ${ }^{27}$, a German electrical engineer living in London. Kapp had written fundamental books on the calculation and construction of serially built dynamos, and he had also invented the phase converter named after him. His books had initial print-runs of 1500: all of them had to be reprinted. The costs of his first book were covered by the profits on sales after the first year. As Springer wrote to the author "This is a result which is really very rare for a German technicalscientific book."

The differing judgments at that time about translations can be gauged from the fact that the London publisher Whitaker asked for only $\mathfrak{E}_{10}$ for the publishing rights of Kapp's Elektrische Kraftübertragung (Electrical Power Transmission) and another $\mathfrak{E} 12$ for the leasing of the printing blocks (zinc blocks and wood engravings). The author received $\mathfrak{E} 20$ for surrendering the translation rights, while the two translators received $50 \%$ of the profits. However, there were no standards for agreements between author, original publisher and translator (see p. 130 f.).

Springer offered some English texts, for which sufficient sales for a German translation could not be expected, in the original edition, e.g. the nine titles of the London publishing house The Electrician, while the latter sometimes reciprocated by distributing the Elektrotechnische Zeitschrift in English-speaking countries. Occasionally translations of German technical books into other languages had already been published. By the time of the First World War the translation licences were fairly evenly balanced.

The constitutional assembly of the Elektrotechnischer Verein (Electrotechnical Society) took place on December 20, 1879. 
„The Electrician“-Series.

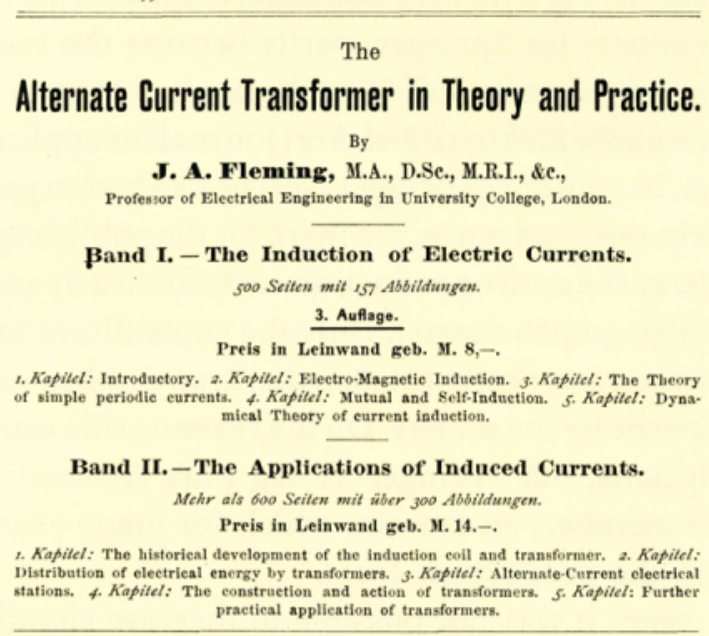

Magnetic Induction in Iron and other Metals.

J. A. Ewing, M.A., B.Se.,

Professor of Meehanism and Applied Mechanies in the University of Cambridge. 370 Seilen 'mit t50 Abbildungen. Preis in Leinwand geb. M. 12,--

Practical Notes for Electrical Students.

Laws, Units and simple Measuring Instruments. By

A. K. Kennelly and H. D. Wilkinson, M.I.E.E.

3ao Seiton mit 155 Abbildungen.

Preis in Leinwand geb. M. 7,50.

Zu bezichen $\cdot$ durch die

Verlagsbuchhandlung von Yulius Springer in Berlin N., Monbijouplatz 3.

,The Electrician" - Series.

The $\underset{\text { of }}{\text { A r t }}$

Electrolytic Separation of Metals.

(Theoretical and Practical.) $\mathrm{By}$

George Gore, LL.D., F.R.S.

Mehr als goo Seilen mil tor Abbildungen. Preis in Leinwand geb. M. 12,- .

Electro-Chemistry.

George Gore, LL.D., F.R.S. Zwoite Auflage.

Preis in Leinwand geb. M. 3,--

Ein sehr werthvolles Buch über Elektro-Metallurgie, das von grösstem Nutzen für jeden Jünger der Erzkunde ist.

A Practical Treatise

on

The Steam-Engine Indicator and Indicator Diagrams. Edited by

W. W. Beaumont, M.I.C.E., M.I.M.E., \&e.

190 Seiten mit 116 Abbildangen.

Preis in Leinwand geb. M. 4,50.

In Vorbereitung befinden sich:

Electrical Engineering Formulae, \&c. By W. Geipel and H. Kilgour.

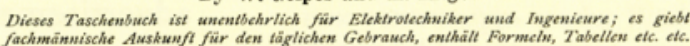

Electro-Magnetic Theory. By Oliver Heaviside.

Submarine Cable Laying and Repairing. By H. D. Wilkinson, M.I.E.E.

Das Legen unterseeischer Kabel ist hier nach durchaus praktischen Gesichtspunkten
behandelt.
Zu bestichen durch die
Verlagsbuchhandlung von Yulius Springer in Berlin N., Monbijouplatz 3.
The initiative came from Werner Siemens who had asked the Postmaster-General Heinrich Stephan to be patron. The term Elektrotechnik, so obvious to us today, had been coined by Siemens on May 2, 1879 in a letter to Stephan.

From the start the society had plans for its own periodical. As both Stephan and Siemens had good contacts to Springer-Verlag and the Springer family, and since Karl Eduard Zetzsche, editordesignate, was professor at the Dresden Polytechnic and had been a Springer author for some years, Springer-Verlag was in a good position to bid for publication of the journal. In fact, positive assurances had already been given, so that, when the contract was finally signed on January 13, 1880, the journal's first issue was already out.

The breathtaking growth of the electrical engineering industry in Germany, closely bound at first to the name of Siemens but soon also to that of Rathenau (AEG), was effectively sup-
96 Advertising leaflets listing English books in electrical engineering which were of great interest to specialists. All these books were distributed by Springer. 


\section{ELEKTROTECHNISCHE ZEITSCHRIFT.}

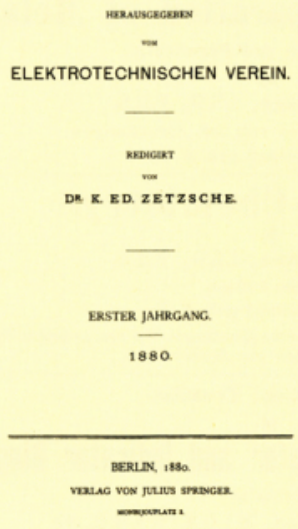

97 Cover page of the first volume of the Elektrotechnische Zeitschrift whose appearance was much appreciated: "A veritable flood of spiritual life flows towards us from the contents of the first volume of this journal, something which gives an indestructible attraction to the young life of such a new and mighty subject. All through his life Werner Siemens looked with particular favour upon the Elektrotechnische Verein, because it gave reality to long-felt needs" [MATSCHOSS (2): 175]. ported by the founding of the Elektrotechnischer Verein and its journal. Nonetheless, taking over the publishing of the journal in 1880 was a risky business for Springer, partly because the year before the Munich publisher Rudolf Oldenbourg had started a Zeitschrift für angewandte Elektrizitätslehre (Journal for applied study of electricity). In addition, Springer-Verlag also had to pay the society, quarterly and in advance, 750 mark for the publishing rights and had to carry the entire production costs for nearly 500 pages ( 12 issues of five quarto sheets). Only the expenditure for wood block illustrations was limited at 1800 mark: any additional expense had to be borne by the society. On the revenue side were members' subscriptions, but Springer-Verlag only received 6 mark annually per member, an amount which for many years failed to meet even the production costs.

In the first few years it was not possible to increase significantly the earnings from advertisements, because at the founding assembly Siemens had spoken against acquisition of any advertising. Presumably a compromise was reached whereby advertisements could only appear on the cover pages and "if necessary, pages which were to be identified as advertising inserts." The publisher was entitled only to accept advertisements of "commercial and literary content," as well as those for "situations vacant." The editor had to be shown the advertising section before it was printed, and he had the right to refuse "dubious advertisements" without giving reasons.

Despite the unfavourable starting conditions the Elektrotechnische Zeitschrift or ETZ, as it soon came to be called, developed into a profitable undertaking for the publishing house, and by 1888 there were two issues every month. However, it soon became apparent that the competing journal from Munich reflected advances in electrical engineering more accurately. The editor of the Springer journal, E. E. Zetzsche, and also his successor had concentrated on low-voltage technology. In its first few years most of the society's members were engineers and officials in the low-voltage industry and telegraphy, so this onesidedness was not perceived. With the development of highvoltage technology a counter-movement started which led to the founding of a new association, Verband Deutscher Elektrotechniker. This thought of making the Centralblatt für Elektrotechnik (Central Journal for Electrical Engineering) (formerly the Zeitschrift für angewandte Elektrizitätslehre [Journal for Applied Electricity] but renamed in 1883), published by Oldenbourg, its official organ. 

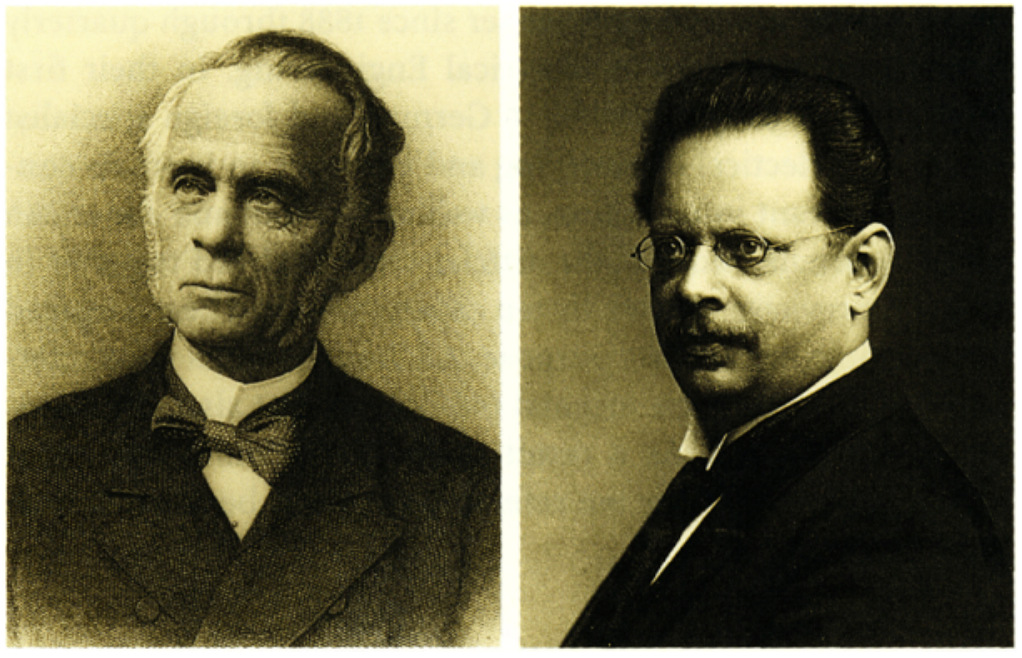

98 Rudolf Oldenbourg (1811-1903), who founded his publishing house in Munich in 1858. He became joint publisher with Springer of the merged Centralblatt für Elektrotechnik and Elektrotechnische Zeitschrift.

99 Adolf Slaby (1849-1913). He had met Springer at the Schwartzkopff home and helped arrange the merger and then co-publication of the two electrical engineering journals.

However, thanks to the intercession of Adolf Slaby, a childhood friend of Fritz Springer and also co-editor with Zetzsche of the ETZ in $1883 / 84$, the two journals combined under Friedrich Uppenborn, Oldenbourg's editor, in 1889 . The two publishers also agreed on joint publication in future of their books on electrical engineering.

The journal saw a remarkable growth spurt in the 1890 . Tram lines were being laid in the larger German cities and electric motors were becoming more and more important. During this decade the number of subscriptions to the journal nearly doubled, reaching 7200 in 1900 . The agreement with Oldenbourg had originally been for 12 years, but in 1901 Springer decided not to renew it. Because the two publishing houses were in competition in many areas of technology Springer thought the joint enterprise should not continue. Furthermore, Oldenbourg had opened a branch in Berlin in 1901, under the direction of a former Springer employee, and this could have led to conflicts of interest. Springer therefore took over the journal as well as the jointly published titles for a payment of 300,000 goldmark.

By the end of 1903 ETZ had 8300 subscribers, but - as is so often the case with society journals - the conditions became ever more unfavourable for the publisher. The journal continued to be owned jointly by the Verband Deutscher Elektrotechniker and the Elektrotechnischer Verein as their organ, the former becoming sole owner in 1948.

The growing importance of electrical engineering is also reflected in the steadily increasing amount of publications. This 
development was met by Springer since 1888 through quarterly Reports on Advances in Electrical Engineering. In their first year, these already reviewed 26 German and foreign specialist journals in electical engineering and a further 30 journals containing relevant information, as well as German and American patent journals. Most of the articles were analysed together in collective reviews, written by ten experts who had been engaged by the publisher for this purpose. All contributions were referenced - not only their orignial publication but also any translation, excerpt etc. As a result many of the more important articles had as many as ten references to them because of multiple publications.

Werner von Siemens. $\Lambda$ mong the many prominent Springer authors in technology Rudolf Diesel $\mathrm{A}$ in the late nineteenth and early twentieth centuries, two should be particularly emphasised:

Werner von Siemens (1816-1892) - he had been knighted by Emperor Friedrich in 1888 - had his books published by Julius Springer from his first one in 1851 (Kurze Darstellung der an den preußischen Telegraphen-Linien mit unterirdischen Leitungen bis jetzt gemachten Erfahrungen (Short Description of the Experiences Gained So Far with the Underground Conduits of the Prussian Telegraph Lines); see p. 41). Springer, his party colleague, also published Siemens' political pamphlets against Prussia's rearmament, Zur Militärfrage (On the Military Question), which he had written at the request of the delegates of the Progressive Party. Lastly, Siemens had been in touch with the firm when the ETZ had been founded; and it was on his recommendation that it had been published by Springer since 1880 . That same year Siemens had gone to the firm with a proposal to publish together in a book his many scattered technical articles and talks. His famous address to the Academy (1867) Über die Umwandlung von Arbeitskraft in elektrischen Strom, ohne permanente Magnete (Transformation of mechnical power into electrical current without a permanent magnet), in which he explained the principle of the electrodynamo, which he had discovered and from which the development of high-voltage technology had originated, was particularly important to him.

Neither author nor publisher had great hopes for the sales of this book of nearly 600 pages. Siemens decided to forego his royalties so that the publisher could set a reasonable price 


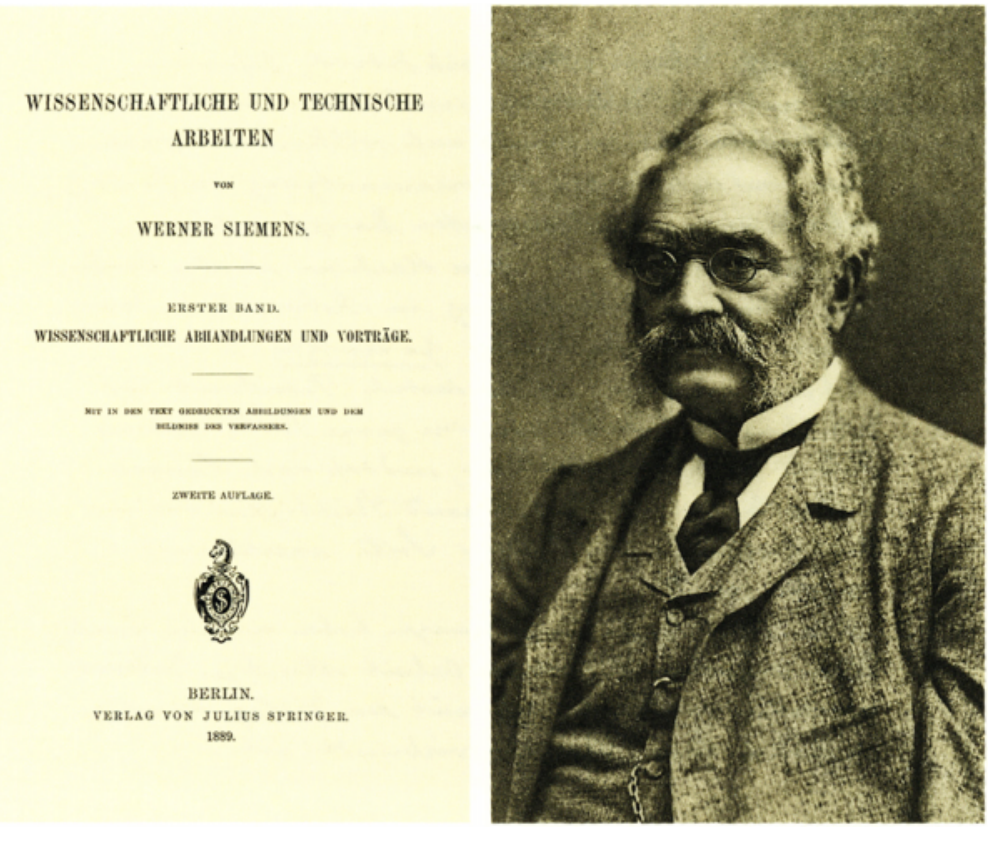

100 Title page of the first edition of Siemens' Collected Papers, published in a single volume by Springer in 1881. The two volumes of an enlarged second edition appeared in 1889 and 1891.

101 Werner (von) Siemens (1816 to 1892).

despite a small print run. In the event, thanks to the relatively low price, the book sold out in five years (1886). A more extensive edition could now be planned, as Siemens had published extensively in the 188 os.

There were eventually two volumes of "scientific and technical writings" totalling nearly 1000 pages. Originally there was to be a third volume of Memoirs, but this ultimately appeared separately, one week after Siemens' death on December 6, 1892.

Siemens was not only a brilliant engineer and scientist but also a good businessman. For his memoirs he had signed a contract which was then quite unusual for Springer-Verlag: the author paid the entire production costs, while the publisher was given $40 \%$ of list price for each copy sold to look after the book's production, promotion and distribution. The remainder, if any, went to the author. As Springer-Verlag had to give on average about $30 \%$ discount to the book trade, it received only $10 \%$ to cover costs. This was not very much, but Springer will have decided exceptionally to forego any surplus because of the author's fame [Davidis (2):3ff.].

Rudolf Diesel (1858-1913) had been the director of the Berlin branch of the Gesellschaft für Linde's Eismaschinen (Society for Linde's Ice Machines). It was probably obvious to him that he 
102 Part of the last page from $R u$ dolf Diesel's letter of October 2, 1892 explaining to Springer the basic properties of his motor and offering his book on it ("...it will awake general interest and there fore the publisher will surely not take any risk..."). He received the patent for his invention on February 23, 1893.

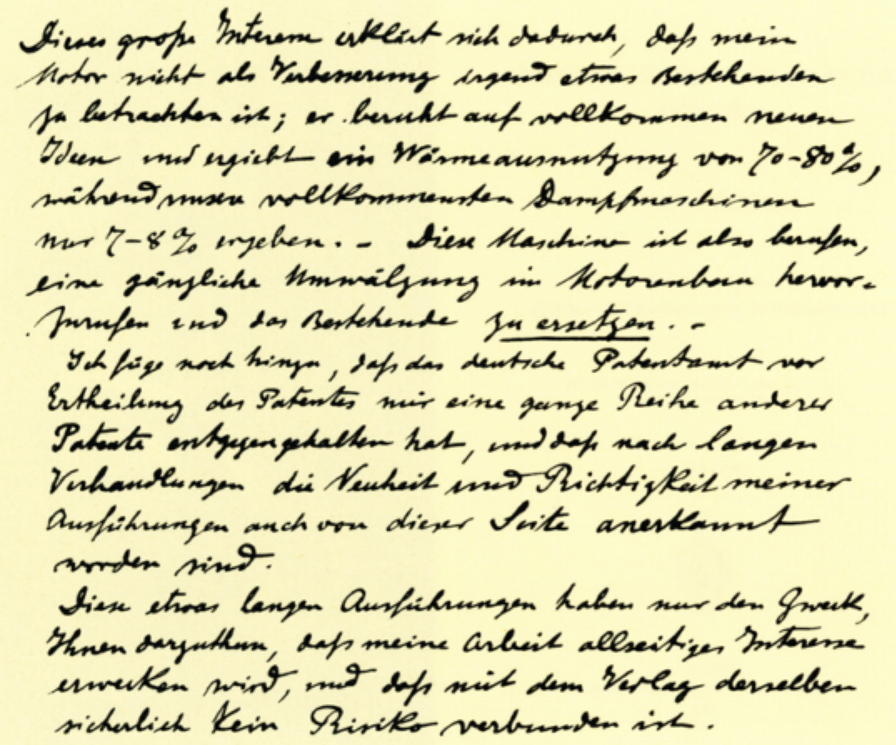

should offer his first manuscript Theorie und Konstruktion eines rationellen Wärmemotors (Theory and Construction of an Efficient Heat Motor) first to a local publishing house, especially as it was the leading German one in the area of machine construction. His submission of October 2, 1892 contained the remarkable statement that his "motor should not be considered as an improvement on any existing one; it is based on completely new ideas and achieves a heat efficiency of $70 \%-80 \%$, while our most complete steam engine provides only $7 \%-8 \%$. This machine is thus destined to bring about a total upheaval in motor construction and to replace what exists now" (see Fig. 102).

Springer responded by return of post and a contract was signed five days later. The print run was to be 1000 copies and the author was to receive half of the net profits. The book was ready only ten weeks after the contract had been signed and the author praised the "nice make-up."

Initially review copies were sent to 12 specialist periodicals and four supra-regional daily newspapers. But this was not enough for Diesel. He named 12 more journals, three general periodicals and three dailies which had not been on the Springer list. Free copies were sent to university professors and industrialists - rather more than had been stipulated in the contract. Not least because of this massive promotion, Diesel's book became widely known and helped Diesel in his licensing negotia- 


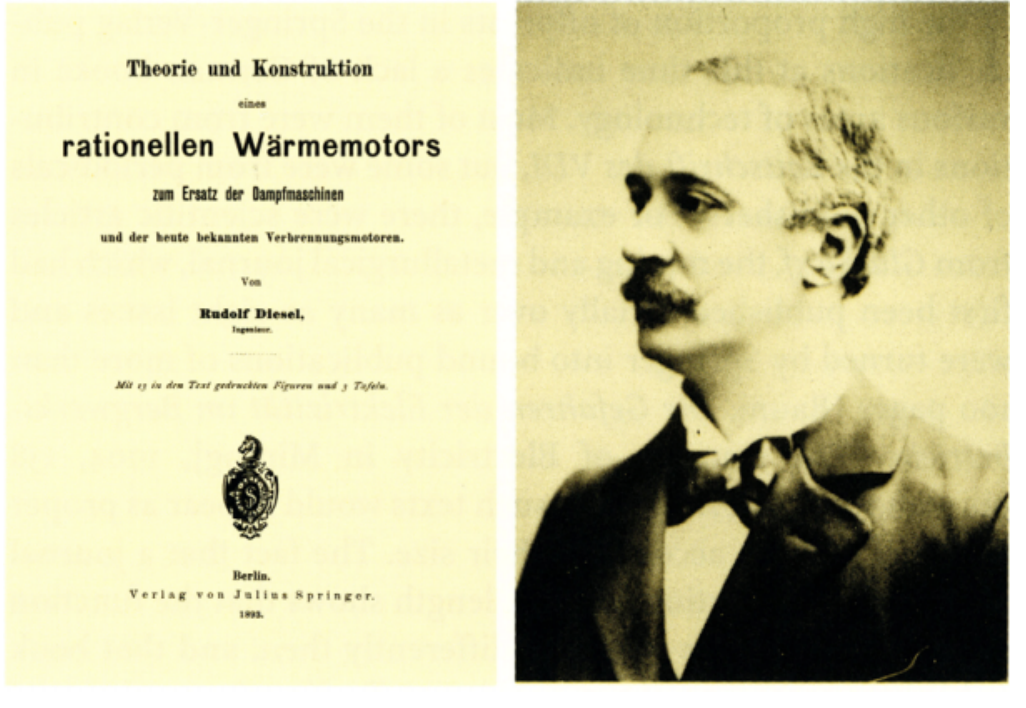

103, 104 Diesel's book The Theory and Construction of an Efficient Heat Motor, came out only ten weeks after signing of the publishing agreement. It had sold out five years later. tions with MAN (Engine Factory Augsburg/Nuremberg), Krupp and Sulzer, which were concluded in the next five months.

The book had sold out five years later and the author could well be satisfied with his financial reward, receiving 1000 goldmark as his share of the net profits, corresponding to a $25 \%$ royalty on list price.

Diesel's claims about his motor's efficiency were vehemently denied, because the statements about the degree of heat utilisation had to be revised. When the first Diesel engine was presented to experts in Augsburg in 1897, after four years of development, the measured efficiency rate was only $26 \%$. However, even this was twice that of the petrol engine and three times that achieved by the steam engine. The Diesel engine gave other advantages, as it used the cheaper heavy oil and was more reliable than the petrol engine. Diesel was self-assured but also self-critical and he gave his opinion on his motor's efficiency at the 1897 annual meeting of the Verein Deutscher Ingenieure $(V D I)$ at Kassel. His talk, together with another speaker's presentation, was published by Springer as a special printing.

Diesel's last book, Die Entstehung des Dieselmotors (The Origin of the Diesel Engine), was completed by Springer-Verlag three weeks before his death on September 29/30, 1913.* There was to be no new edition, because the book had too much of the character of a fighting pamphlet [cf. DAvidrs (2): $9 \mathrm{ff}$.].

\footnotetext{
* Diesel killed himself by jumping overboard when crossing in a steam-
} ship from Calais to Dover. 
Journal Articles Turn into Books

The high proportion of offprints in the Springer-Verlag publications at this time indicates a lack of German books in various areas of technology. Most of them were from contributions in the Zeitschrift des VDI, but some were from periodicals of other publishers. For example, there were scientific articles from Glückauf, the mining and metallurgical journal, which had first been published serially over as many as eight issues and were turned by Springer into bound publications of more than 100 pages (Baum, Die Gefahren der Elektrizität im Bergwerksbetriebe [The Dangers of Electricity in Mining], 1904, 138 pp. with 109 figs.). Nowadays such texts would appear as proper books, if only on account of their size. The fact that a journal published contributions of such length shows that the function of technical journals was seen differently then, and that book publishers were not always able to talk directly to potential authors.

Two examples will show the importance of journal offprints in the area of technology. In 1902, at the annual meeting of the VDI in Düsseldorf, Aurel Stodola, professor at the Eidgenössisches Polytechnikum (later Technische Hochschule) in Zurich had given a talk on steam turbines. Fritz Springer, who had attended the meeting, had asked the author for permission to publish and distribute offprints after publication in the journal. After covering all costs, the profits were to be divided equally between author and publisher, as was customary with the firm. In his letter Springer did not rule out the possibility of Stodola wishing to widen the contract, which he would be interested in. The author replied at once: "I am indeed wondering whether a short textbook on the construction of steam engines could naturally develop from my contract."

In March 1903 an expanded version of the talk was printed in the Zeitschrift des Vereins Deutscher Ingenieure (VDI) (Journal of the Society of German Engineers). So that it would not be too long, the author had omitted many passages which he wanted to include in the edition Springer was planning. To stress that it was an independent publication, the text in the book version was set in a single column, rather than in the two-column journal format. Dozens of letters now went to and fro. The rather difficult author was against the format suggested by Springer (largely basing it on the column width of the journal), and suggested going back to two columns. When Fritz Springer had dissuaded him Stodola wanted a few more lines on the page, 

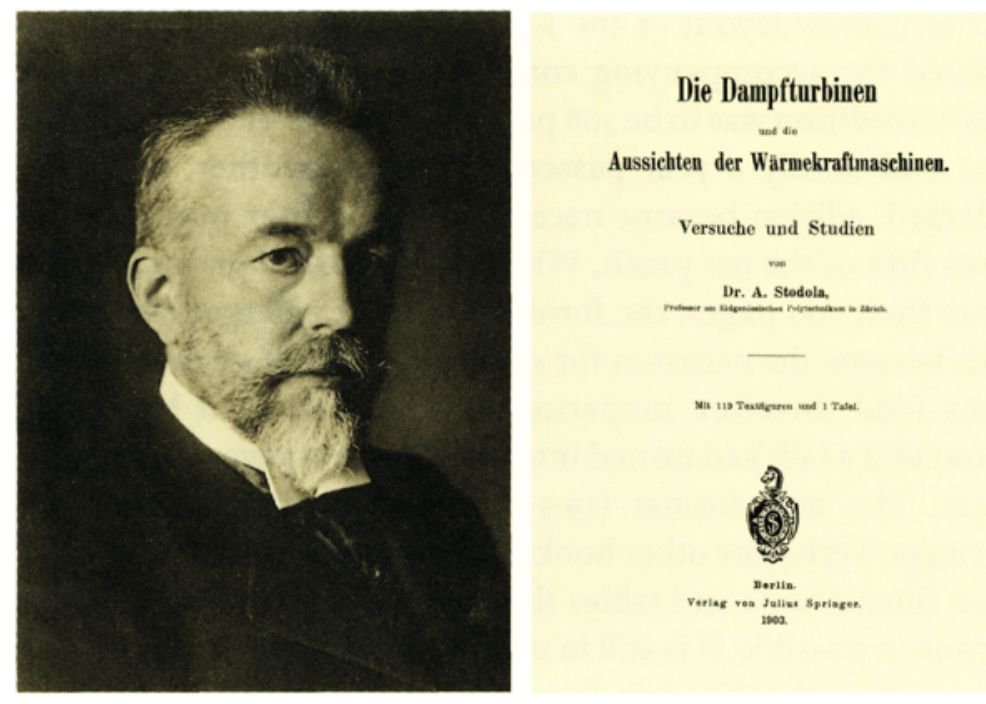

then asked for the text to be centred on the page (contrary to all custom), and finally proposed a print-run of only 600, instead of the planned 1000 copies, so that he could soon plan a new edition.

The "offprint," which had now grown to 220 pages, was at last ready on September 23, 1903, but a week later a telegram arrived from Zurich in which the author asked for a new printing of the final four pages "in an enlarged form." Another telegram came the same afternoon: Stodola had noticed too late a gross error in the section on gas turbines and Springer-Verlag was to recall all copies, by telegraph, and await the new manuscript! Even this could not upset Springer. He wrote back that he was pleased to be able to fulfil the author's wishes, as the books were packed and stamped, and ready for dispatch, but did not need to be recalled. However, the book had already been invoiced, together with other new publications, so that new invoices had to be written for all bookshops that had ordered copies.

The first copy of the corrected text was sent to the author on October 10,1903, and he approved it. Springer did not wish to dwell on the additional costs, which the author had agreed to meet: "It is gratifying for me to have been of service to you in this matter."

The book sold out in one month and Springer wanted to issue an unrevised reprint. Stodola refused to consider this. He was firmly in favour of an edited and enlarged edition, essential for no other reason than the many corrections and additions. Furthermore, he would then be free from the limitations of the
105, 106 Aurel Stodola (1859-1942). An academic engineer of Hungarian origin, he was professor at the ETH (Eidgenössische [Federal Swiss] Technische Hochschule) in Zurich from 1892 until 1929. His fundamental publication on the steam engine, subtitled The potentials of heat energy engines: experiments and studies, had its origin in a talk which Stodola delivered in Düsseldorf at the annual meeting of the Association of German Engineers in 1902. 
107 Title page of Heinrich Dubbel's Entwerfen und Berechnen von Dampfmaschinen (Design and Calculation of Steam Engines. A textbook and handbook for students and future construction engineers). First published in 1905 it went through four further, progressively larger, editions.

Entwerfen und Berechnen

\section{Dampfmaschinen.}

fur Studierende und angehende Konstrukteure.

Heinrich Dubbel,
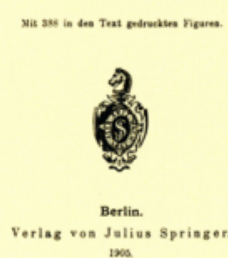

rather narrow layout of the first edition which somewhat restricted the accompanying construction drawings. In the end this new edition was to be 368 pages, $50 \%$ more than the original one, and hardly a year passed before yet another, markedly enlarged, edition became necessary. The author now received three fifth of the net profit. When, in 1910, the book comprised more than 700 pages, the format had to be enlarged yet again. This became the occasion for redrawing almost all the illustrations (and therefore preparing new blocks). So it had come about that a talk had turned into a book of 1111 pages ( 5 th edition 1922). The new format $(19.5 \times 27.5 \mathrm{~cm})$ became standard at Springer-Verlag for other books that were so rich in the detail of their illustrations and tables that they required as large a page format as possible. It is still in use today, where appropriate, and is known as the "Stodola format."

The contact with Heinrich Dubbel - later the editor of the Taschenbuch für den Maschinenbau (Manual for Engine Construction) - came about in a similar manner, the result of an offprint of an article by him in the Zeitschrift des VDI. Occasionally the author, not yet 30 years old, criticised the work of the publishing house in his letters: "I allow myself on this occasion to put the following proposal before you: Published works, some of them yours, about pumps, blowing engines, conveyors etc. have the great drawback that they are too large and thus too expensive, and that too diverse topics are treated between their covers. If, e.g., someone wished to inform himself about blowing engines, he would have to get [Albrecht von] Jherings' book [Die Gebläse (The Blowers) Springer 1893] and put up with [and pay for] the presentations about air pumps, circular pumps etc." In their stead Dubbel suggested monographs by "eminent engineers" and proposed some topics.

Dubbel's letter, sent from Aachen on June 25, 1902, reached Fritz Springer the next day and was answered positively by return of post. Springer asked whether Dubbel would be willing to edit such a collection "with well-known specialists." Although this particular idea was not to be realised, some monographs did appear. Dubbel's own book Entwerfen und Berechnen der Dampfmaschinen (Design and Specifications of Steam Engines) appeared in 1905, as will be discussed further (see p. $210 \mathrm{f}$.). 
$\mathrm{T}$ he chemical industry had developed rapidly since the middle of the 1860s. Meister, Lucius \& Co. (later Farbwerke Hoechst), Farbenfabrik Friedr. Bayer and Kalle \& Co. were founded in 1863 , followed by Badische Anilin- und Soda-Fabrik (later BASF) in 1865. They soon grew to large-scale industries. There was an abrupt fall in prices for synthetic dyes and a ruinous price war, which worsened in subsequent years [RUSKE: $42 \mathrm{f}$.]. In reaction to these developments a society was formed in Germany to protect the interests of the chemical industry (Verein zur Wahrung der Interessen der chemischen Industrie Deutschlands). Its journal, Die chemische Industrie, was published by Springer from January 1878 onwards. But there were continual complaints from its editor, Emil Jacobsen, to the society, and they also became an ever greater burden for Springer-Verlag. It was therefore decided to found Springer's own journal in January 1887, Zeitschrift für die chemische Industrie mit besonderer Berücksichtigung der chemisch-technischen Untersuchungsverfahren (Journal for the Chemical Industry, with special consideration of chemical-technical investigative methods) known since 1888 as Zeitschrift für angewandte Chemie (Journal of Applied Chemistry). Ferdinand Fischer was appointed editor and on his initiative the Deutsche Gesellschaft für angewandte Chemie (German Society for Applied Chemistry) was founded and the journal soon became its official organ. Members received the journal free of charge. With a membership fee of 20 mark and the same subscription price for the journal it seemed likely that those already subscribing would join the society.

Springer-Verlag was paid only a relatively small amount per subscription by the society. It will have tried to increase other, fully priced, subscriptions as well as revenues from advertisements, not only to cover the true costs of the member subscriptions, but also to achieve a profit. This was something of a balancing act, a situation well known to this day to publishers of society journals. When on the proposal of Carl Duisberg the society decided, at its annual general meeting in 1896, to change its name to Verein Deutscher Chemiker (Association of German Chemists) nothing changed in principle, but the society's financial demands on the publisher rose further. From 1904 onward Springer published the journal merely on commission, even though he had founded it. Finally, in 1907, Springer-Verlag gave up publishing the journal, as it had by then become unprofitable. The Leipzig publisher Spamer took it over.

\section{Chemistry \\ and Foodstuff Research}

108 Title page of Zeitschrift für die Chemische Industrie (Journal for the Chemical Industry, with special consideration of chemicaltechnical methods of investigation). On January 1, 1888 it changed its name to Zeitschrift für angewandte Chemie (Journal for Applied Chemistry) and became the organ of the German Society for Applied Chemistry.

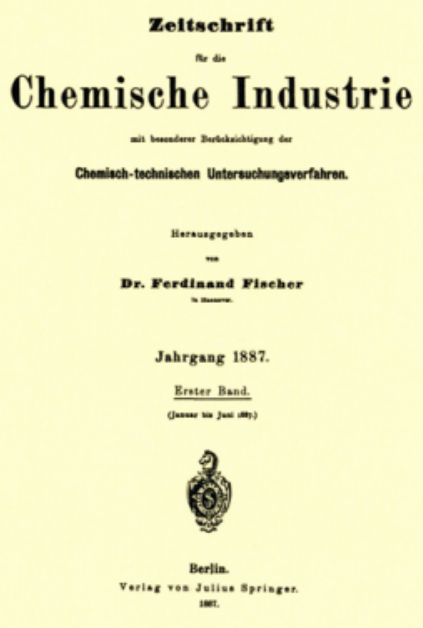


Fortschritte

\section{Theerfarbenfabrikation}

und verwandter Industriezweige

$1877-1887$.
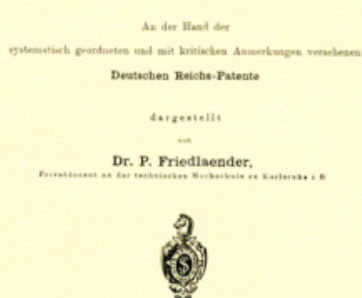

Berlin.

109 Title page of Advances in the Manufacture of Aniline Dyes and Related Branches of Industry. It was edited by Paul Friedlaender (1858-1923) who from 1877 onwards worked with Adolf von Baeyer on the synthetic production of indigo. In the widest sense he made the manufacture of indigo derivatives his life's work. In parallel to this he brought out, from 1888 until his death, 13 voluminous collections of patent analyses relating to aniline dye manufacturing.
In the course of his 35 years as a publisher Julius Springer brought out some 60 books related to chemistry, an average of two a year. Although this was quite a modest output, it did show his interest in the subject.

In founding the journal Die chemische Industrie (1878) Springer-Verlag had indicated that chemistry was to play a greater part in its programme, and it confirmed this further in 1880 with the publication of the Chemiker-Kalender. This calendar, which was to go through 57 editions by 1936, took over from Chemischtechnische Mitteilungen (Reports), which had been published by Springer since $\mathbf{1 8 4 8}$, but with ever increasing specialisation was no longer appropriate for the times.

Practical matters were covered also in Chemisch-technische Untersuchungsmethoden der Groß-Industrie (Chemical-Technical Investigative Methods in Large-Scale Industry). This twovolume work was first published in 1884; two expanded and revised editions were soon required. The fourth edition, edited by Georg Lunge, came out in 1899/1900, in three volumes of more than 2700 pages. By the time of the sixth edition (1909/12, in four volumes), Ernst Berl was the editor: henceforth it became known simply as "Lunge/Berl". Its continually revised editions remained in the list until the 1930s. Fortschritte der Theerfarbenfabrikation und verwandter Industriezweige (Advances in the Manufacture of Aniline Dyes and Related Industrial Branches) was also long-lived. Started by Paul Friedlaender in 1888 it was continued under the editorship of Hans Eduard Fierz-David from 1926 until 1942.

In addition to such large works, which were revised and continued over decades, there were numerous monographs on methods of chemical analysis. In the last third of the nineteenth century the analysis of chemical substances was at the centre of research. However, most of the eminent analytical chemists of the day were not Springer authors, because the company's strength lay in applied chemistry, or chemical technology as it was then called. A large proportion of books was on dye chemistry (Springer founded a Färber Zeitung [Dyers' Paper] in 1889) and the chemistry of oils, fats and soaps (a journal, Der Seifenfabrikant [Soap Manufacturer] had been started by the firm in 1881), as well as on leather, textile and paper chemistry.

Springer-Verlag was less successful with its textbooks. Kurzes Lehrbuch der anorganischen Chemie (Short Textbook of Inorganic Chemistry) by Alfred Ditte, along thermochemical lines, and Lehrbuch der theoretischen Chemie (Textbook of Theoreti- 


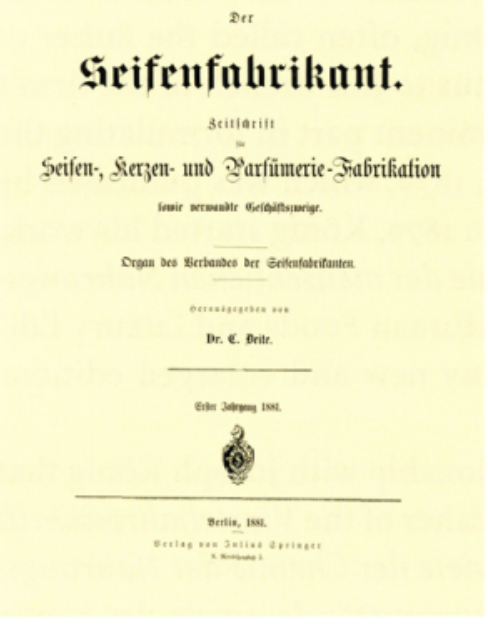

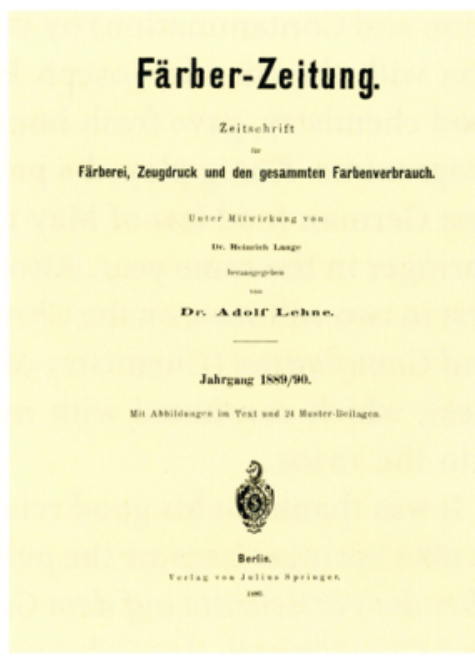

110, 111 Title pages of Der Seifenfabrikant (Soap Manufacturer: journal for soap, candle and perfume manufacturing) and Färber-Zeitung (Dyers' Paper; for dyeing, materials printing and all forms of colour usage). Both journals were founded in response to the rapid progress in chemical research. Seifenfabrikant was continued as Zeitschrift der deutschen Öl- und Fettindustrie (Journal of the German Oil and Fat Industry). During the first years of its existence the chemist Paul Friedlaender, then a lecturer at Karlsruhe, was scientific adviser to Färber-Zeitung.

cal Chemistry), published in 1903 in two volumes, were both failures. Other publishers had been dominating this field for decades.

Springer's success in chemistry largely went back to contacts he had made with his Zeitschrift für angewandte Chemie. His authors included many industrial chemists. The prominent scientists of the day tended to publish elsewhere, especially with Vieweg who was popular with chemists because Liebig, Bunsen and Fresenius were among his authors. No-one of the stature of Van't Hoff, Kopp or Ostwald was then in Springer's list. However, when he started to publish Emil Fischer's books from 1906 onwards (see p. $188 \mathrm{ff}$.) the company benefitted from his immense prestige.

By the end of this period Springer-Verlag's reputation as a publisher of books on chemistry had however risen greatly, as can be seen from the enquiry by the Deutsche Chemische Gesellschaft, on June 1, 1906, as to the possibility of Springer publishing the fourth edition of Beilstein's Handbuch der Organischen Chemie. In the end the society decided on the Leipzig publisher Wilhelm Engelmann. But ten years later, when the first volume was to come out, Engelmann no longer had enough capital and the society signed a contract with Springer-Verlag (see p. $231 \mathrm{ff}$.).

Springer was interested in food chemistry from his early days as a publisher (cf.list on p.119). The first title in this area appeared in 1875, Die Nahrungsmittel des Menschen, ihre Verfälschungen und Verunreinigungen (Human Foods, their Adulter- 


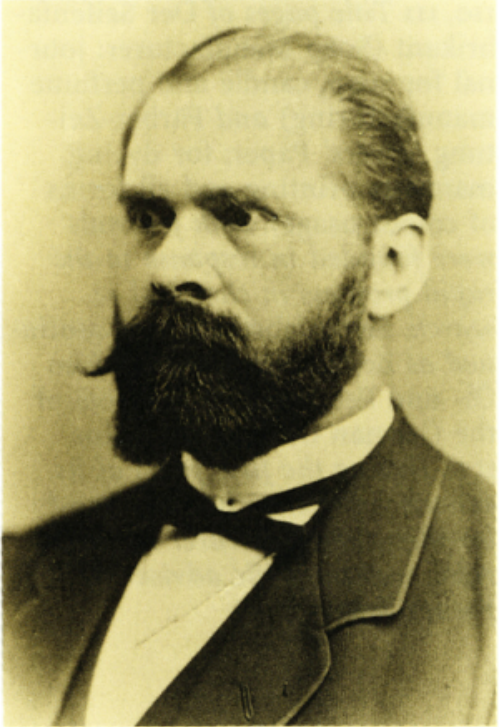

112 Even as a young man Joseph König (1843-1930) was so widely respected as an agro-chemist that he was asked to advise on the first German food law of 1879 . He wrote Chemie der menschlichen Nahrungs- und Genußmittel (Chemistry of Human Foods and Luxury Edibles), which first appeared in $1878 / 80$ in two volumes. He was co-founder of the Vierteljahresschrift über die Fortschritte auf dem Gebiet der Chemie und der Nahrungs- und Genußmittel (Quarterly Journal of Advances in the Field of Chemistry of Foods and Luxury Edibles), and served as a senior editor until his death.

113 Song-Book for Jolly Forgers. Edited by the Council and General Association for the Adulteration of Foods, Goods Etc. In this little booklet Emil Jacobsen and Hermann Hager, senior editor of the Industrie-Blätter (Industry Pages), anonymously parodied the misuse of chemicals in the production of ordinary and luxury foods. The songs were to be sung to melodies of folk and student songs. ation and Contamination) by Walchner. The additional connection with the chemist Joseph König, often called the father of food chemistry, gave fresh impetus to this branch of the firm's programme. König played a prominent part in formulating the first German food law of May 14, 1879, which was published by Springer in the same year. Also in 1879 , König started his work, first in two volumes, on the Chemie der menschlichen Nahrungsund Genußmittel (Chemistry of Human Foods and Luxury Edibles), which continued with many new and enlarged editions into the 1920 .

It was thanks to his good relationship with Joseph König that in 1886 Springer became the publisher of the Vierteljahresschrift über die Fortschritte auf dem Gebiete der Chemie der Nahrungsund Genußmittel, der Gebrauchsgegenstände, sowie der hierzu gehörenden Industriezweige (Quarterly on the Advances in the Field of Chemistry of Foods and Luxury Edibles, Their Utensils and Related Industries). It was originally intended as a branch publication of Jahresbericht für Agricultur-Chemie (Annual Reports on Agricultural Chemistry), published by Parey. However, both König and his co-editor Albert Hilger preferred SpringerVerlag and Parey gave up his contract with Hilger for a "compensation" of 1000 mark.

The contract stated that the quarterly was to have 320 pages annually, but the first volume had 450 , and by 1894 the journal
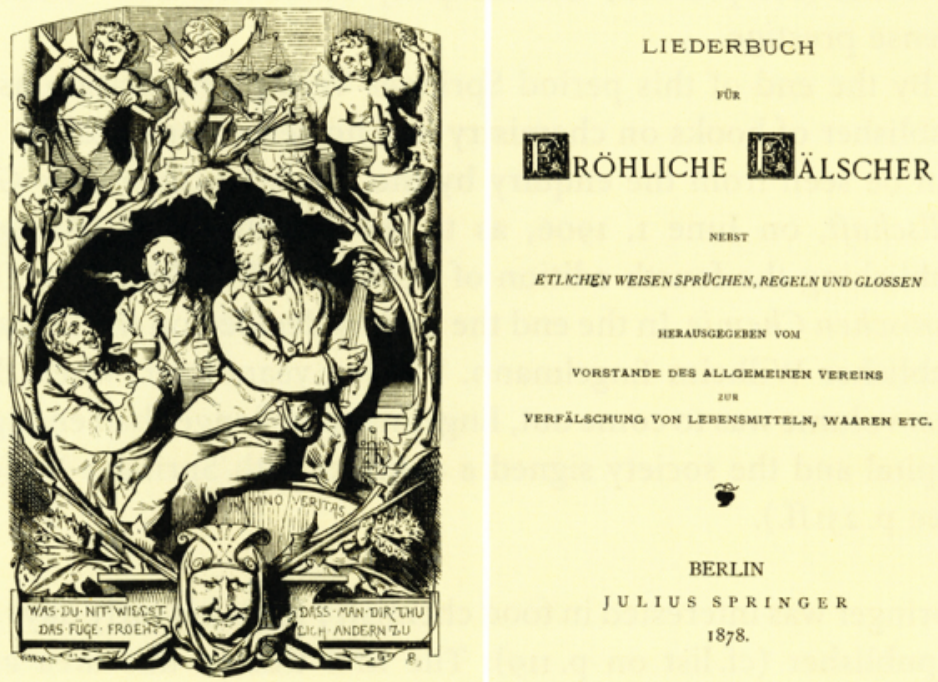

1878 . 
F.H. Walchner: Die Nahrungsmittel des Menschen, ihre Verfälschungen und Verunreinigungen. 1875 .

Fritz Elsner: Untersuchungen von Lebensmitteln und Verbrauchsgegenständen, zugleich als Beitrag zur Frage der Lebensmittelverfälschungen, ausgeführt im Laboratorium des Vereins gegen Verfälschung der Lebensmittel. 1878.

Emil Jacobsen: Liederbuch für fröhliche Fälscher. Nebst etlichen weisen Sprüchen, Regeln und Glossen. Herausgegeben vom Vorstand des allgemeinen Vereins zur Verfälschung von Lebensmitteln, Waaren etc. 1878 .

Wilhelm Zopf: Entwicklungsgeschichtliche Untersuchung über Crenohtrix polyspora, die Ursache der Berliner Wassercalamität. 1879 .

Joseph König: Chemie der menschlichen Nahrungs- und Genußmittel. Vol.2: Die menschlichen Nahrungs- und Genußmittel, ihre Herstellung, Zusammensetzung und Beschaffenheit, ihre Verfälschungen und deren Nachweisung. 1880 .

Hermann Schülke: Gesunde Wohnungen. Eine gemeinverständliche Darstellung der Einwirkungen des Lichtes, der Wärme, der Luft, des Wassers und des Untergrundes der Gebäude und ihrer Umgebung auf die Gesundheit der Bewohner. 1880 .

Friedrich Wilhelm Toussaint: Die ökonomische Vertheilung und Benutzung von Boden und Wasser. Eine nationalökonomische Studie im Interesse des Waldschutzes und einer verbesserten Ernährungsbilanz durch Förde- rung der Wasserwirthschaft. 1882 .

James Bell: Die Analyse und Verfälschung der Nahrungsmittel. Two vols. $1882 / 1885$.

Joseph König: Über die Principien und die Grenzen der Reinigung von fauligen und fäulnißfähigen Schmutzwassern. 1885.

Hofmeier: Vandalismus an der $\mathrm{Na}$ tur. Ein Notschrei aus Friedrichroda von einem alten Kurgast. 1887.

Robert Koch: Bericht über die Untersuchung des Berliner Leitungswassers in der Zeit vom 1.Juni 1885 bis 1. April 1886, ausgeführt im hygienischen Institut der Universität Berlin. 1887 .

Joseph König: Die Verunreinigung der Gewässer, deren schädliche Folgen, nebst Mitteln zur Reinigung der Schmutzwässer. 1887.

Eugen Sell: Über Branntwein, seine Darstellung und Beschaffenheit in Hinblick auf seinen Gehalt an Verunreinigungen, sowie über Methoden zu deren Erkennung, Bestimmung und Entfernung. 1888.

Ferdinand Fischer: Das Wasser, seine Verwendung, Reinigung und Beurtheilung mit besonderer Berücksichtigung der gewerblichen Abwässer. 1891.

Carl Mez: Mikroskopische Wasseranalyse. Anleitung zur Untersuchung des Wassers mit besonderer Berücksichtigung von Trinkund Abwasser. 1898.

Eugen Rost: Borsäure als Konservierungsmittel. Beiträge zur Beurteilung der Angriffe gegen das Verbot der Verwendung von Borsäure und deren Salzen bei der Zubereitung von Fleisch. 1903.

Wilhelm Ohlmüller, R. Heise und Friedrich Auerbach: Untersuchung über die Beschaffenheit des zur Versorgung der Haupt- und Residenzstadt Dessau benutzten Wassers. 1906 .

Gutachten des Reichs-Gesundheitsrates über den Einfluß der Ableitung von Abwässern aus Chlorkaliumfabriken auf die Schunter, oker und Aller. Berichterstatter: Wilhelm Ohlmüller, Carl Fränkel und Georg Gaffky. 1907.

Gutachten des Reichs-Gesundheitrates, betreffend die Verunreinigung der Orla und Kötschau durch gewerbliche Abwässer. Berichterstatter: Karl Heinrich v. Buchka und Friedrich Georg Renk. 1908.

Wilhelm Ohlmüller: Die Untersuchung und Beurteilung des Wassers und des Abwassers. Ein Leitfaden für die Praxis und zum Gebrauch im Laboratorium. 1910.

Joseph König: Neuere Erfahrungen über die Behandlung und Beseitigung der gewerblichen Abwässer. Vortrag gehalten in der Sitzung des Deutschen Vereins für öffentliche Gesundheitspflege am 15. September 1910 in Elberfeld. 1911.

Gutachten des Reichs-Gesundheitsrats, betreffend die Versalzung des Wassers von Wipper und Unstrut durch Endlaugen aus Chlorkalium-Fabriken. Berichterstatter: Heinrich Beckurts, Albert Orth und Oskar Spitta. 1911.

Hartwig Klut: Untersuchung des Wassers an Ort und Stelle. 1911.

List 4 Water and air pollution by industry, as well as increasing use of harmful food preservatives alarmed the population and government. These problems appear in the Springer book programme (titles in chronological order) 
had grown to 680 pages. The increase in production and editorial costs by nearly $50 \%$ was only partly offset by a rise in the subscription price from 10 to 13 mark. Profitability was not restored until it became a monthly journal, in 1898 , under the name of Zeitschrift für Untersuchung der Nahrungsmittel (Journal for Food Investigation) and took over another journal in the field: with a total of 900 pages annually the subscription was raised to 20 mark. In 1902 the journal became the organ of the Freie Vereinigung Deutscher Nahrungsmittelchemiker (Free Association of German Food Chemists). Now called Zeitschrift für Lebensmittel-Untersuchung und -forschung (Journal for Food Investigation and Research) it is the oldest journal still published by Springer-Verlag from its first issue. Although Springer-Verlag publishes journals that are much older, these had been acquired and not started by the company.

Pharmacy Tulius Springer recognised the advantage of specialisation within pharmacy as early as the 1860 . He brought his steadily growing programme to the notice of pharmacists or reminded them of it through Hager's Pharmaceutische Centralhalle (Central Pharmaceutical Journal), Pharmaceutischer Kalender (from 1861) and Pharmazeutische Zeitung (from 1885).

Hager's Handbuch der pharmaceutischen Praxis, concluded as a two-volume work with delivery of its final, 22nd, instalment $^{28}$, was the publisher's most important book in this area, next to eight other books by the same author. The book was reprinted in 1880,1882 and 1883 and a 1300-page supplement, brought out in 12 instalments, was completed in 1883 . There was lively interest from abroad, as is shown in the promotion of the supplement. For example, Ferdinand Springer persuaded the bookseller Carl Ricker in St. Petersburg, to send out a promotional mailing in which all pharmacists in Russia were sent sample instalments, bound in their own cover. A knowledge of German among Russian pharmacists was still taken for granted. In addition, the Wilhelm Frick Court Bookshop in Vienna asked to promote the book in all possible ways, including sending 2000 samples to all pharmacists, institutions etc. in Austria, in return for Springer's agreement not to send substantial amounts of promotional material to other Austrian bookshops. By 1893 nine editions had been published. After Hager's death (in 1897) a new edition, prepared by eight specialists, continued the book's successful run, which lasts to this day. 


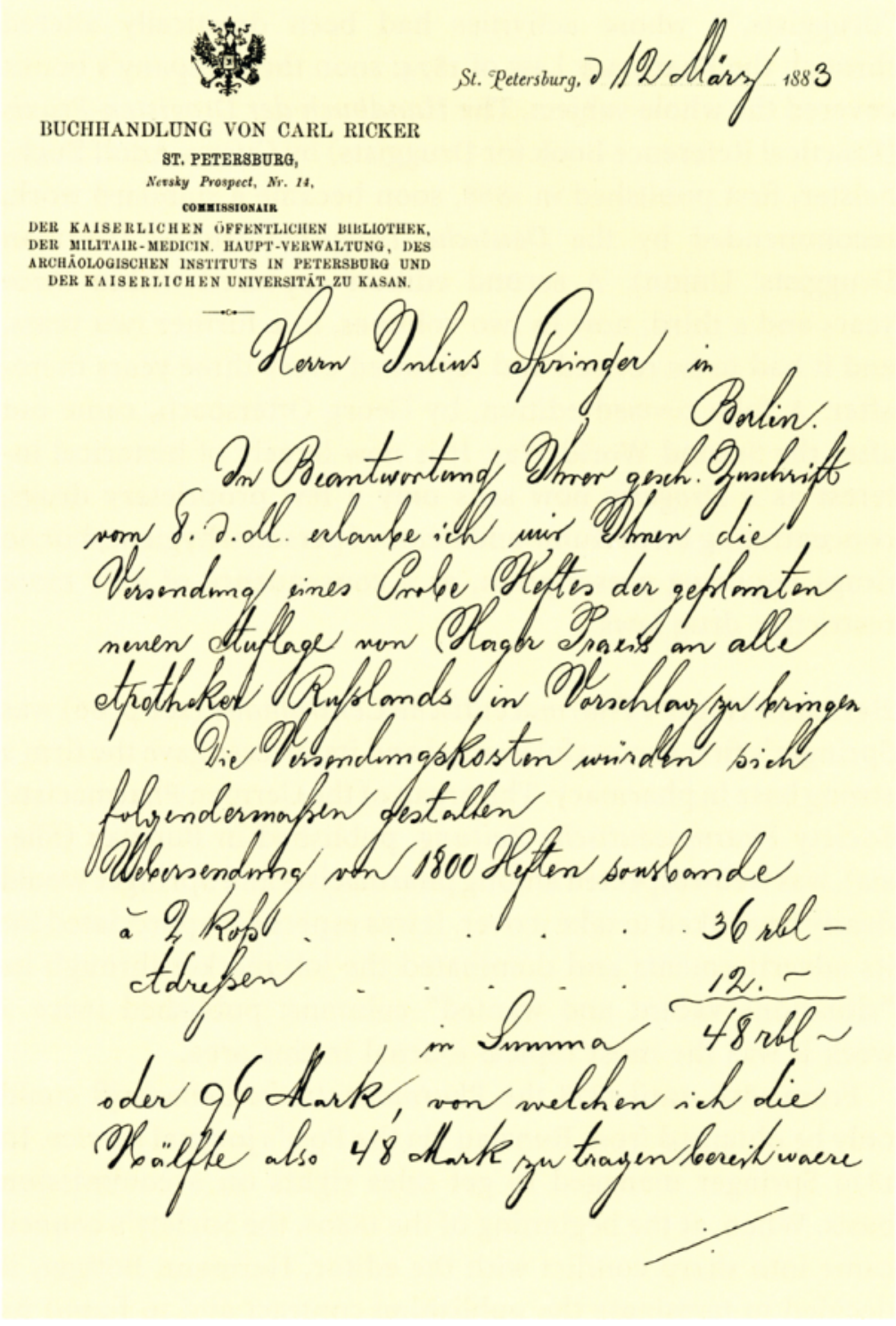

114 Carl Ricker, a bookseller in St. Petersburg, sent out 1800 specimen copies of the planned new edition of Hager's Handbuch der pharmaceutischen Praxis to all pharmacists in Russia, Springer paying half the delivery costs ( 48 goldmark).

A five-volume Schule der Pharmazie (School of Pharmacy), edited by five specialists, appeared in 1893/94 and was already in its third, revised edition by 1905 . Other successful contemporary authors - whose names are still well known among pharmacists today - included Hermann Böttger, editor of Pharmazeutischen Zeitung, with no fewer than 13 books; Eugen Dieterich; Theodor Husemann, author of Handbuch der gesamten Arzneimittellehre (Reference Book of Pharmacology); Hermann Schelenz, historian of pharmacy; and Ernst Urban. 


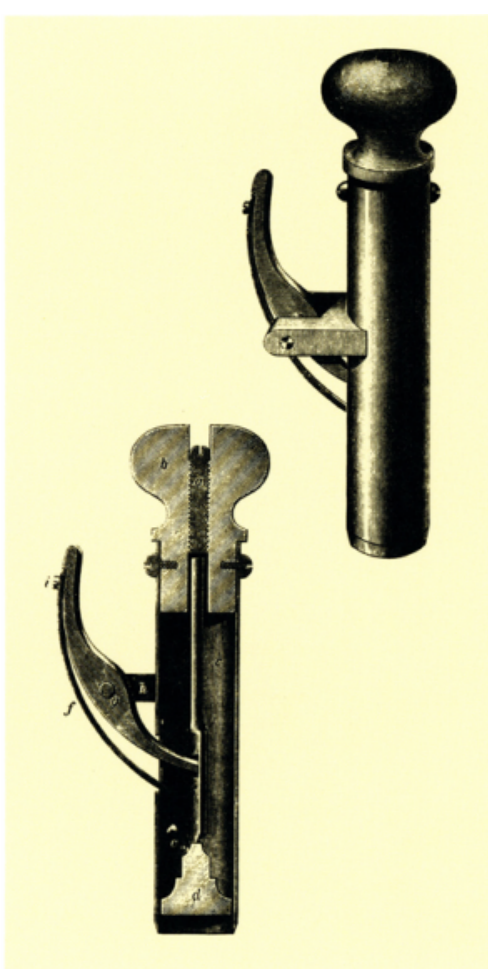

115 Picture of a tablet punch, from Vol. 1 of Schule der Pharmacie (School of Pharmacy), published by Springer in 1893. At that time most of the prescribed medications were made by the pharmacists. If there was a great demand, they would be produced and stocked in quantity.
Meanwhile Springer-Verlag had expanded its publications for "druggists,"* whose activities had been drastically altered through the Pharmacy Law of 1874: soon the company's books covered the whole subject. The Handbuch der Drogisten-Praxis (Practical Reference Book for Druggists) by Gustav Adolf Buchheister, first published in $\mathbf{1 8 8 8}$, soon became a standard work, recommended by the Deutsche Drogistenverband (German Druggists' Union). A second edition appeared within three years and a third, now in two volumes, in a further two years, and it had to be revised and reprinted every three years thereafter. A fully revised edition, by Georg Ottersbach, came out after the Second World War. It is now largely of historical interest as a Drogerie now sells only a few proprietary drugs, concentrating on perfume and items of personal hygiene, but no drugs requiring prescription, as a consequence of ever more restrictive drug laws.

Hermann Hager's Pharmaceutische Centralhalle (see p.66) was Springer's first successful journal and its success gave the firm a strong base in pharmacy. The organ of the German Pharmacists' Society Pharmaceutische Zeitung, published in Bunzlau (Silesia), was well-respected among pharmacists and Springer would dearly have liked to take it over. It was especially appreciated for its advertisements and dominated the job market through its "situations vacant and wanted" columns: published twice a week it was the most topical journal in this area.

From 1856 until 1878 the Pharmaceutische Zeitschrift could only be obtained from Bunzlau via the Post's journal service. In 1879 Springer managed to get sales rights on a commission basis. When, at the beginning of the 1880 os, the Society's council came into sharp conflict with the editor, Hermann Böttger, it decided to terminate the publishing contract and to found its own journal. The Springer brothers visited the publisher-owner in Bunzlau and persuaded him to move the editorial office, production and distribution to Berlin and grant them $25 \%$ of a joint ownership. From that time on the journal grew rapidly, reaching a paid circulation of 7950 in 1906.

* Although Drogist derives from the German word Droge (drug; from the French drogue), a Drogist - unlike an Apotheker (apothecary; dispensing or pharmaceutical chemist) - was not allowed to dispense medications that required a doctor's prescription. A Drogist, therefore, concentrated on selling herbal preparations, pesticides, paints, wallpaper, stain removers, etc., plus items of personal hygiene, including perfume. 
Böttger was a highly knowledgeable pharmacist but a rather difficult character, with a high turnover of editorial assistants. In 1900 he was succeeded by Ernst Urban who edited the journal skilfully until 1933. Urban also managed to establish peace with the the Society and to continue the journal's successful run.

The Pharmaceutische Rundschau, founded in 1883 and edited by Friedrich Hoffmann, is rather an oddity among the pharmceutical periodicals. Described as a "journal for the scientific and commercial interests of pharmacy and related professional and business branches in the United States" it was printed in New York where Hoffmann lived. Springer-Verlag had the sales rights for Europe.

There were then many German-speaking pharmacists living in the USA. The journal met their interests through reports of topical issues. "The Rundschau, with its numerous original contributions by American and European scientists, as well as those by Hoffmann, met the highest professional and journalistic demands and was among the few qualitatively valuable American specialist journals in the nineteenth century" [KNOLL SCHÜTZE, personal communication]. A New Yorker Pharmaceutischer Leseverein (Reading Society) had been formed in 1851 for the numerous German-speaking pharmacists, especially in New York, and The New Yorker Apotheker Verein developed from it in 1864 and lasted until the Second World War [WANKMÜLLER: $1327 \mathrm{f}$.].

At the end of 1895 Hoffmann sold his journal to an American, Edward Kremers, who renamed it Pharmaceutical Review: it became an English-language journal. Springer-Verlag continued to sell it until 1901 when the firm ceased to be its publisher on commission.

\section{Pharmaceutische Rundschau und$$
\text { 갈 } \mathrm{it} \text { m }
$$$$
\text { fûr die }
$$$$
\text { wissenschaftlchen und gewerblichen Interessen der Pharmacie }
$$$$
\text { und verwandten Berufs- und Geschaftszweige }
$$$$
\text { in den Vereinigten staaten. }
$$$$
\text { Herausgegeben von Dr. FR. HOFFMANN. }
$$

116 Head of title page of Pharmaceutische Rundschau und Zeitung (Review and Journal), published in New York for a readership in the United States. Springer distributed it in Europe. 
Medicine T Tntil the middle of the 1880 s medicine played an unimportant part in Springer-Verlag's publishing programme. Two medical journals, founded in 1857 and 1859 by Julius Springer, were short-lived. There were a few titles on public health and hygiene, and these may explain why Springer was successful in his bid for the weekly Veröffentlichungen des Kaiserlichen Gesundheitsamtes (Publications of the Imperial Public Health Office), previously handled by Verlag Grosser, Berlin. The change of directorship of the Office may also have played a part. Heinrich Struck, its first director, had left at the end of 1884. His successor Karl Köhler, a lawyer who had been in charge of public health questions within the Imperial Ministry of the Interior, was known to the Springer brothers [STÜRZBECHER (3): $225 \mathrm{f}$.].

The very first issue, in the second half of 1885 , showed evidence of the new direction. The previous format $(25 \times 40 \mathrm{~cm})$, appropriate for a daily newspaper, was not really suitable for an official bulletin and was changed to a handier quarto size $(18.5 \times 26.0 \mathrm{~cm})$.

117 Karl Köhler (1847-1912), from 1885 to 1905 director and from 1890 president of the Imperial Public Health Office. During those years it steadily widened its scope (medical statistics, laws on animal epidemics, smallpox vaccination, fight against cholera and tuberculosis). On Köhler's suggestion the Gesundheitsbüchlein (Public Health Booklet) was published (see Fig. 121).

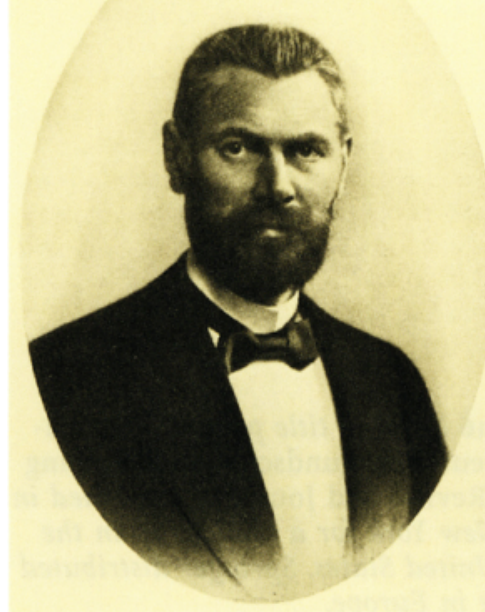

Even more important than this Bulletin was the publication of the Arbeiten aus dem Kaiserlichen Gesundheitsamte (Works from the Imperial Public Health Office), designated as supplements to the Bulletin, which appeared annually from 1886 in one or two volumes of two or three issues. Some issues were also published separately if they were of more general interest, for example the report on cholera in Egypt by Robert Koch and Georg Gaffky. This series is not likely to have been very profitable, but to Springer its financial advantage was less important than giving the firm a certain name among medical people. The intention of building up a medical programme becomes recognisable.

Therapeutische Monatshefte (Therapeutic Monthly), which started in 1887, was Springer-Verlag's first medical periodical. Planning for the journal will have started at least a year befor the launch date. The Springers had expert advice from Heinrich Curschmann, a cousin-in-law, who had been their father's doctor during the last years of his life. Over many years he helped in developing the medical programme. From 1879 he was director of the municipal hospitals in Hamburg where, under his guidance, the General Hospital in Eppendorf was built. In 1888 he was appointed director of the Medical Clinic in Leipzig and became professor of special pathology and therapeutics. Through him Ferdinand Springer came into contact with Oscar 


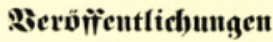

\section{fanilerlidjen (beriund)pitsantes.}

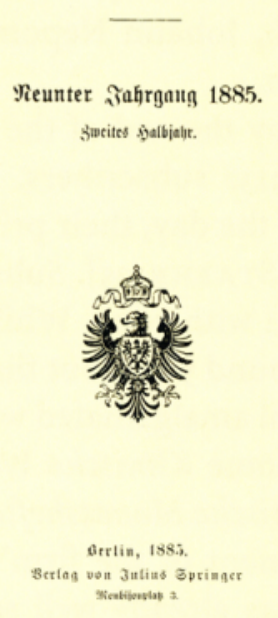

\section{Therapeutische Monatshefte.}

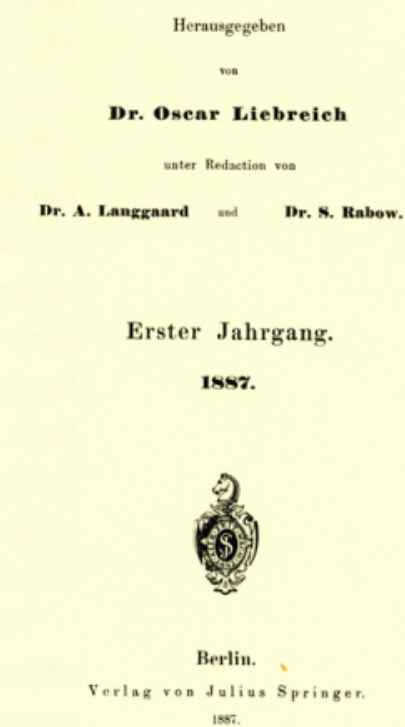

Liebreich, who was later director of the Pharmacological Institute of Berlin University and became the journal's senior editor. Alexander Langgaard and Siegfried Rabow were the executive editors.*

The journal clearly met the needs of the time. The practising doctor was confronted by a flood of new drugs for which the manufacturers were promising miraculous results. The new journal soon established itself as a recognised authority in the area. Even in those days doctors had "no time to work through the mountain of medical communications in other medical periodicals... the amount of presented material makes it impos-

* It was common in Germany for the editorial direction of periodicals (series and journals) to have two "levels", Herausgeber and Redaktion (or Schriftleitung). The former consisted of well-known, senior leaders in a given area or specialty. They would set the general aim and scope of the publication, as well as being expected to support the periodical by publishing at least some of their own and their department's work in it. In these pages they are called senior editors or members of the editorial board. The members of the Redaktion or Schriftleitung were most often (but not always) more junior. They usually acted as "desk editors" and their responsibility lay in the day-to-day running of the periodical. In these pages they are called editors or executive editors.
118, 119 Title pages of two periodicals (Publications of the Imperial Public Health Office and Therapeutic Monthly), which gave Springer access to a steadily growing market in medical literature. 
sible for him to take in what is most important," as a delighted reader wrote to the publisher. The Deutsche Medicinische Wochenschrift, which the publisher Georg Thieme had just taken over from Georg Reimer, welcomed "the new undertaking, whose direction is in the most capable hands, as highly topical." The authors of the Monatshefte were recognised scientists. Even during its first year it had contributions by Ernst von Bergmann, Otto Binswanger, Paul Ehrlich, Johann Nepomuk von Nussbaum and Hugo von Ziemssen.

Success came quickly, and by the end of the first year Therapeutische Monatshefte had 4138 subscribers. This was more than other medical journals of the day, their print-runs having been between 1000 and 2000 [STAEHR:25]. Subscription numbers reached their peak in 1892 with 7000 . While the numbers fell later, they still averaged around 5000 , but there was a fall in advertising. ${ }^{29}$ In 1921 the journal amalgamated with the Berliner klinische Wochenschrift to become Klinische Wochenschrift.

The success of the Therapeutische Monatshefte had a positive effect on the further development of the firm's medical programme, although the area was already well served by other publishing houses. Thus there was August Hirschwald, in Berlin since 1816, who published books of the "Berlin School". Georg Ernst Reimer was also active, but after his death (in 1885) the publishing house to which he had given his name became less active in medicine and sold the Deutsche Medicinische Wochenschrift to the newly founded Georg Thieme Verlag. As for Ferdinand Enke's publishing house, founded in Erlangen in 1837 , more than $50 \%$ of its book production was in medicine by the time it moved to Stuttgart in 1874 [KuHLmanN: 38]. In Leipzig there was F.C.W. Vogel, under new ownership since 1862 , with an extensive medical programme, among which reference books and archival periodicals provided the core [HoHLFELD]. In Vienna there was Urban \& Schwarzenberg, founded in 1866 , with a successful medical list. Another new publishing house, Toeplitz \& Deuticke (Franz Deuticke from 1886), which also specialised in medicine, was founded in Vienna in 1878. Another two firms which quickly became active in medical publishing were established in 1878: J. F. Bergmann in Wiesbaden [GöTzE; SAMWER] and Gustav Fischer in Jena [LÜTGE]. When Springer began to publish the Arbeiten des Kaiserlichen Gesundheitsamtes (see above) in 1886, Georg Thieme had founded a medical publishing house in Leipzig, the stock of the Kassel publisher Theodor Fischer forming its base [STAEHR:14ff.]. 
There were thus a number of medical publishers when Springer expanded into this area, but this merely strengthened Ferdinand's conviction that it was a growing market with a high success rate. The number of medical students was to more than double from 3195 in 1875 to 7781 in a mere 10 years. One could therefore project a rise in the number of doctors, which would exceed the rate of growth of the population. In the event there were 15,824 doctors in 1887 , a number which grew to 23,910 by 1896.

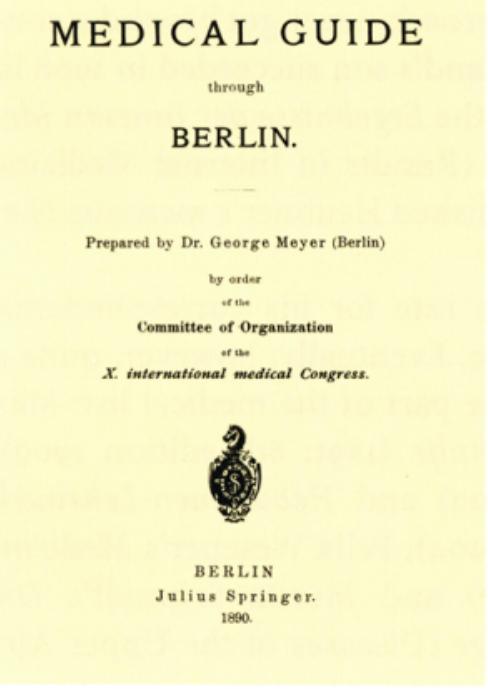

\section{(brfiutù)ritşhiüblein.}

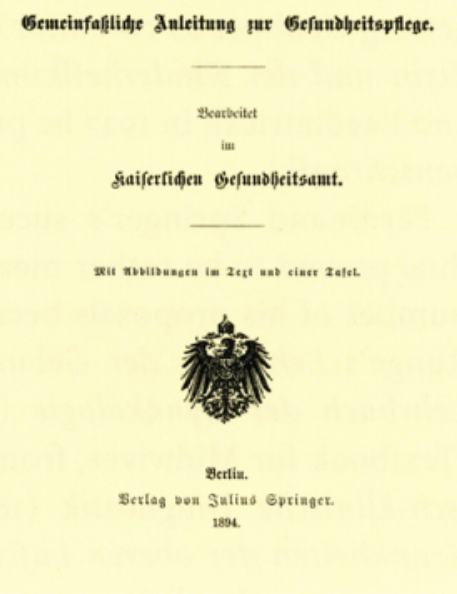

120 Springer-Verlag took over publication of the congress guide (in English, French and German) for the 1oth International Medical Congress, held in Berlin in 1890. 121 The Public Health Booklet, published by Springer since 1894, continued to be a best-seller for half a century.

At first, Springer's medical list specialised in public health and hygiene, the publications from the Imperial Public Health Office making up the bulk of the list for some time. The Gesundheitsbüchlein (Health Booklets) of about 260 pages, edited by the Office, continued successfully into the 1930s. Up to 1906 alone 12 volumes of 10,000 copies each had been printed, with an English edition (A Popular Manual of Hygiene) in 1904. But this translation apparently failed to sell, and there were no others. Between 1889 and 1892 Ferdinand Springer worked hard to build up the medical programme, with textbooks for students and doctors, and one-volume manuals at its core.

Springer wrote to some 20 prominent doctors. This correspondence indicates that he followed the advice given him by his cousin Curschmann, as well as suggestions by Liebreich, Langgaard and Rabow, the editors of the therapeutic monthly. $\mathrm{He}$ tried to persuade Ludolf Krehl, then still in Leipzig, to write a 


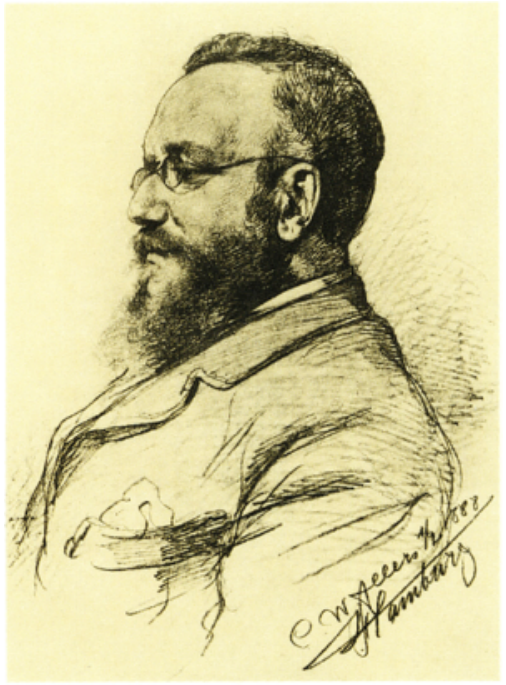

122 Heinrich Curschmann (1846 to 1910), founder of the hospital in Hamburg-Eppendorf (later the university hospital). He advised Ferdinand Springer, his wife's cousin, on building up the firm's medical programme. This portrait was drawn by C. W. Allers, best known for his album of Bismarck portraits. book on heart disease, but he declined saying that he already had a satisfactory arrangement with the local publisher F. C. W. Vogel. For a text- and reference book on pathological anatomy Springer at first aproached Professor Marchand, who declined. He received a similarly negative response from Professor Sattler (Leipzig) about a book in ophthalmology, because he had just signed a contract with another publisher. He approached Professor Neisser (Breslau) about a book in dermatology, also in vain: he thought there was no need for such a book, because there were enough "small textbooks" in this subject and any more were superfluous. Otto Heubner was asked to write a paediatric textbook, but this approach never got beyond a contract proposal. However, Ferdinand's son succeeded in 1908 in getting Heubner as co-editor of the Ergebnisse der Inneren Medizin und der Kinderheilkunde (Results in Internal Medicine and Paediatrics); in 1927 he published Heubner's memoirs (Lebenschronik).

Ferdinand Springer's success rate for his correspondence thus proved to be rather meagre. Eventually, however, quite a number of his proposals became part of the medical list: Max Runge's Lehrbuch der Geburtshülfe (1891; 8th edition 1909), Lehrbuch der Gynäkologie (1902) and Hebammen-Lehrbuch (Textbook for Midwives, from 1904); Felix Wesener's Medizinisch-klinische Diagnostik (1892) and Moritz Schmidt's Die Krankheiten der oberen Luftwege (Diseases of the Upper Airways, $1894 ; 4$ th edition 1909).

Schmerzlose Operationen (Painless Operation) by Carl Ludwig Schleich was particularly successful. It first came out in 1904; by 1909 a much enlarged and revised 5 th edition was on the market. Later the author wrote that many other publishers had turned down his manuscript. But Langgaard, whom he had met as editor of Therapeutische Monatshefte, was ready to help him. The two of them went to meet Springer with the manuscript and "the printing of my first tragedy began the following day," Schleich wrote in his memoirs Besonnte Vergangenheit (Sunny Past) [SCHLEICH:236]. It is unlikely that matters progressed quite this quickly, as it will have taken several weeks for typesetting and printing. Nonetheless, the words illustrate Springer's reputation for the speed of his production process. This, together with accuracy and quality of type and print, was of special advantage in the production of scientific books.

Why did Springer fail to prosper as publisher of medical books during that time? After all, Berlin alone promised to be 


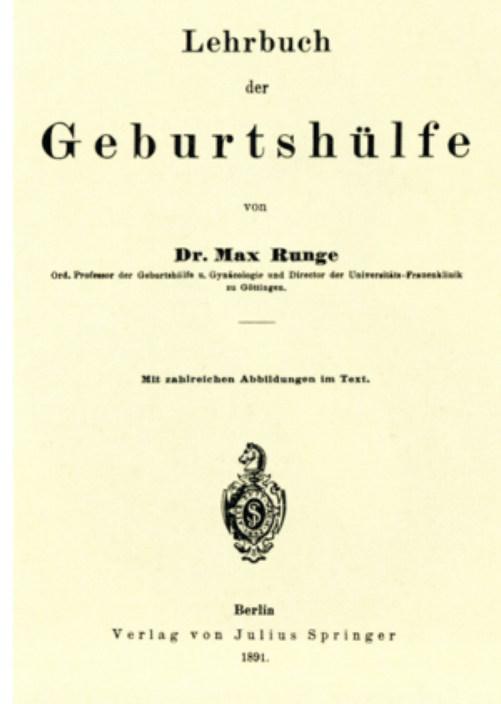

\section{Schmerzlose Operationen.}

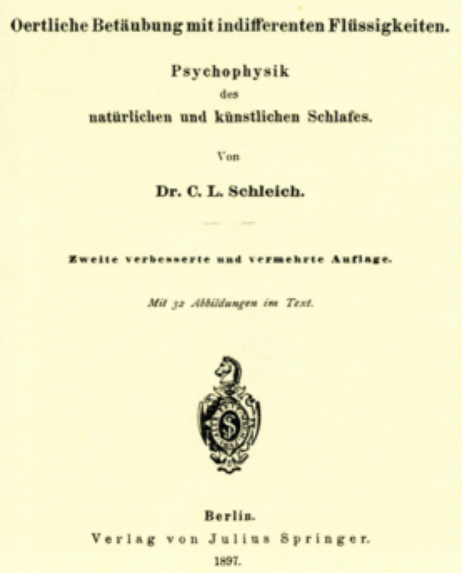

123 Eight editions of the the Lehrbuch der Geburtshülfe (Textbook of Obstetrics), written by Max Runge, had been published by 1908. Under other editors there were four further editions until 1935.

124 Schmerzlose Operationen (Painless Operations: local anaesthesia with neutral fluids. Psychophysics of natural and artificial sleep) by Carl Ludwig Schleich went through five editions, each improved and enlarged.

such a successful site that $S$. Karger founded a medical publishing house there in 1890 and Urban \& Schwarzenberg opened a branch in 1898. In Munich, also, J. F. Lehmann had established itself as a medical publisher and was quickly successful with the Münchener Medizinische Wochenschrift (Munich Medical Weekly). One cannot now know whether the time had not been chosen well or whether Springer lacked a special feeling for the subject and its authors. Whatever, 15 years later his son managed to build a firm basis in medicine and soon led his publishing house to the forefront of medical publishers.

$\mathrm{F}^{\prime}$ rom the middle of the nineteenth century it became clear that the polytechnics would have to teach mathematics more Mathematics and Physics thoroughly to their engineering students [KLEMM: 219ff.]. Springer's mathematics list, with 18 titles, was still quite small at the time, with the exception of teaching texts for Technical High Schools (Colleges). Other publishers, for example B. G. Teubner in Leipzig, had started earlier to contract authors and thus had established an advantage. Springer's list contained a remarkably high proportion of foreign mathematicians in German translation: Abel, Cauchy, Euler, Fourier and Lagrange (all long dead at the time) and Poincaré, the famous contemporary. At the same time, there were the works of two eminent mathematicians of the "Berlin School" in the list: Karl Weierstraß, with Riemann the founder of the modern theory of 
125, 126 Hermann Amandus Schwarz (1843-1921) was professor of mathematics in Göttingen from 1875 to 1892 , in succession to K. Th. W. Weierstraß. Most of his important studies had been written while he was still in Göttingen: these were published by Springer in two volumes in 1890 (Collected Mathematical Treatises).
Gesammelte

Mathematische Abhandlungen

H. A. Sehwarz.
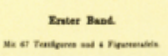

1งตe.

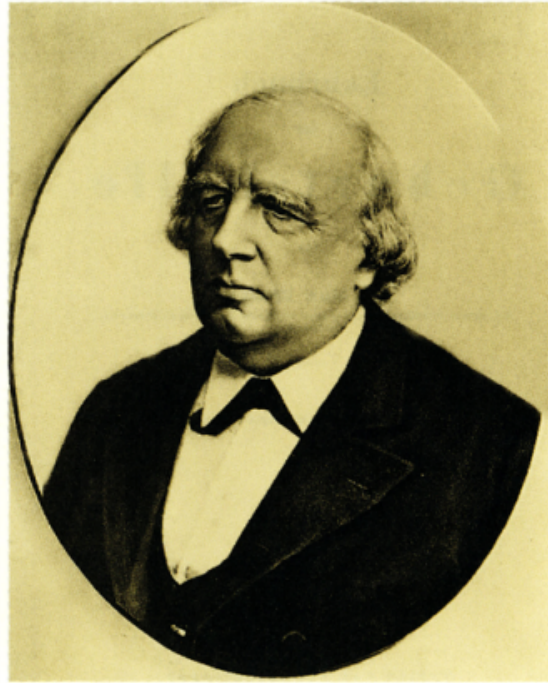

functions, and Hermann Amandus Schwarz, his successor at the University, who gave Springer his two-volume Gesammelte mathematische Abhandlungen (Collected Mathematical Writings) to publish.

Schwarz demanded the highest typographical correctness for the formulas. In his first letter to Springer from Göttingen (on June 2, 1886) he asked that his book "be set at the local University Book Printer (W.Fr. Kästner), which was well equipped for mathematical typesetting. To achieve the highest possible accuracy it is in any case desirable that the author, who in this case is also the main proof-reader in relation to typography, be at the place where the type is set." It is even said of Schwarz that when he found the appearance of formulas unsatisfactory he filed down the type himself to achieve the desired degree of "kerning".

The situation in physics was little different. Eminent German physicists, like Helmholtz or Hertz, had their established publishing connections. In consequence Springer, the newcomer, tried at first to obtain translation rights of books by well-known foreign physicists. Suggestions for authors and accurate translations occasionally came from professors or lecturers at the new Technische Hochschule in Charlottenburg/Berlin. Other advice came from Ferdinand's son-in-law Richard Wachsmuth, a physicist. Among the publications were translations of Faraday's Experimental Researches in Electricity, in three volumes from 1889 to 1891, Maxwell's Electricity and Magnetism (two volumes, 1883) and Lord Kelvin's Gesammelte Abhandlungen zur Lehre von der Elektricität und des Magnetismus, to mention 

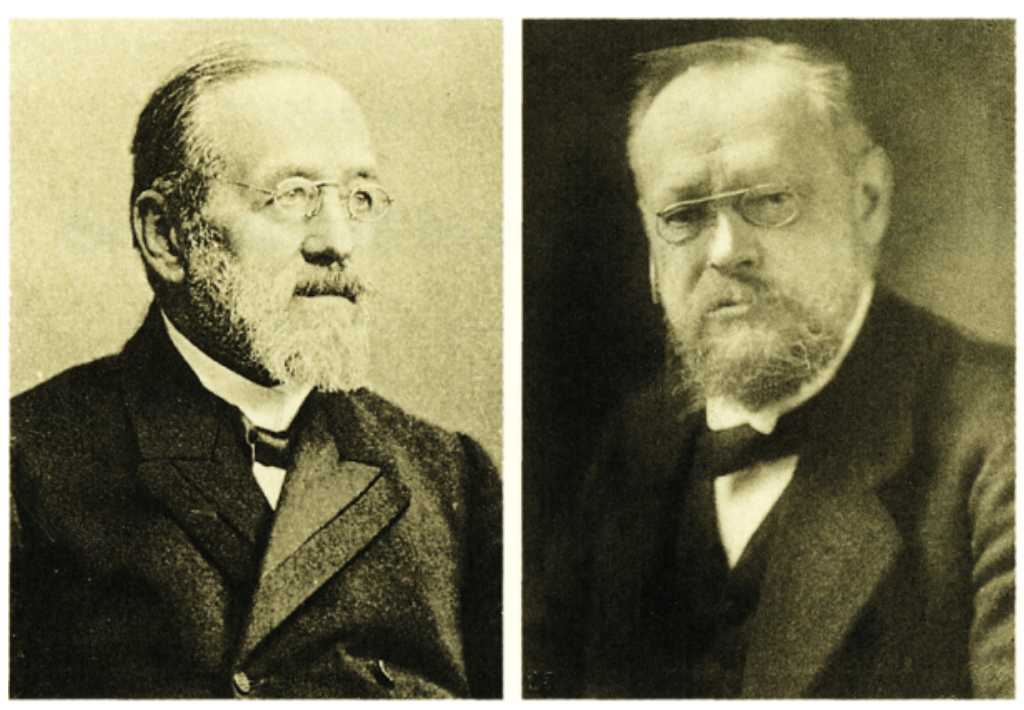

127, 128 (Left) Hans Landolt (1831-1910) and (right) Richard Börnstein (1852-1913) were on the staff of the Landwirtschaftliche Hochschule (Agricultural High School) in Berlin during the 1880 s. They jointly edited the first edition (1883) of the PhysikalischChemischen Tabellen (PhysicalChemical Tables), regularly updated to this day and published under their name. but a few of the works of eminent authors. These three titles about studies in electricity signify Springer's special interest within his technology programme. The licence fees were between 500 and 1000 mark and the translating costs were at least this high. With a print-run of 600-80o copies this meant payments of about $10 \%$ of the list price, due on submission of the translation or publication.

The most important Springer title by a German physicist was Wilhelm Weber's Werke (Works) in six volumes, published between 1892 and 1894. Weber (1804-1891) was one of the "Göttingen Seven." (Cf. p. 4). Together with Gauß he had developed the measurement system for electricity still used today. The most successful publication in this area was Physikalisch-chemischen Tabellen, brought out in 1883 by the physicist Hans Landolt and the chemist Richard Börnstein. By the time of the 3 rd edition, in 1905, 47 scientists were contributors. The latest edition, now in English, consists of 150 volumes.

Ferdinand Springer's intention to expand the publishing list in physics is quite clear. Even at that time he wanted to bring out a physics journal. Zeitschrift für Instrumentenkunde, founded by him in 1881, only covered one branch of physics, albeit an important one. It was a difficult undertaking to found a new journal without a well-respected editor or a certain core of authors. When Johann Ambrosius (known as Hans) Barth died without an heir on January 27,1887 , Ferdinand offered the very next day to buy the business. Barth's list was strong in physics and he had built up excellent national and international contacts through Annalen der Physik, edited by Helmholtz. Springer was 


\section{ZEITSCHRIFT \\ INSTRUMENTENKUNDE.}

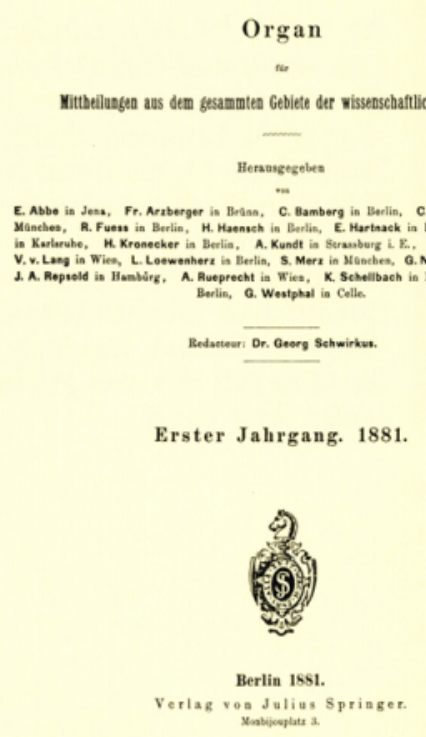

Zeitschrift

Physikalischen und Chemischen Unterricht.

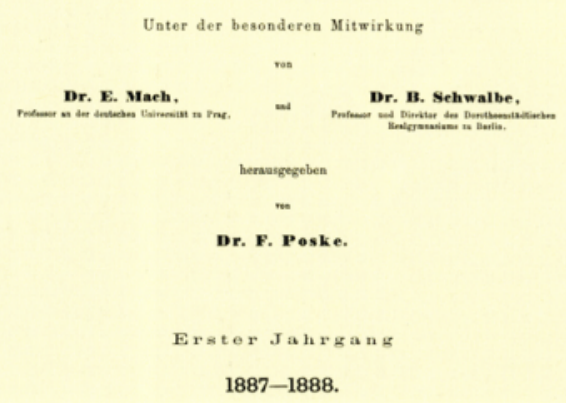

129 The Zeitschrift für Instrumentenkunde (Journal for Instrument Research: Organ for communications in the whole field of scientific technology) owes its foundation to an exhibition of scientific instruments at the 1879 Berlin Trade Fair. Its publication ceased in 1943.

130 The Zeitschrift für den Physikalischen und Chemischen Unterricht (Journal for the Teaching of Physics and Chemistry) also continued publication until 1943. probably also impressed by the much respected Journal für praktische Chemie. But there were no further negotiations and Arthur Meiner bought the publishing house with effect from July 1, 189o. He built it up systematically and widened its range in 1892 by buying the medical publishing firm of Ambrosius Abel.

Springer showed his foresight of the future importance of the natural sciences outside the university area by founding the Zeitschrift für den physikalischen und chemischen Unterricht (Journal for the Teaching of Physics and Chemistry), which began in October 1887. The editors were a teacher, Friedrich Poske, Ernst Mach (later to become an eminent physicist) and the director of a secondary school, Bernhard Schwalbe. As advances in the two subjects were presented in a topical but not too theoretical a manner, this bimonthly periodical probably also attracted readers outside the school system. It continued publication until 1943 when it was ordered to close because of the war. 
$\mathrm{T}$ o the politically deeply involved Julius Springer, politics and current affairs, jurisprudence and constitutional law, economics and transport together formed one unit and, of all the branches of the firm's publishing activities, were closest to his heart. With over 300 titles this part of the list constituted about $30 \%$ of all production and was thus the weightiest in the overall programme (however, this says nothing about its profitability). The publishing volume of the political writings was naturally dependent on the political climate of the times. Caution was necessary after the March 1848 revolution. Until the German wars a definite growth in the programme could be noted, but afterwards there was a certain decline. The liberal Springer had taken in the political conditions and accepted them.

The book titles continue to be a mirror of contemporary questions: Reform des Geldwesens (Reform of the Money System) was brought out in 1869 , and Julius Bluhm wrote on Die bundesstaatliche Einigung Süd- und Norddeutschlands unter Preußens Führung (Unification of South and North Germany into a Federal State under Prussia's Leadership) (1870). In addition to the series Politische Geschichte der Gegenwart (Political History of the Present), of which books appeared annually between 1868 and 1900, there was also a volume on the Geschichte des deutsch-französichen Krieges (History of the Franco-German War) (1871). After the establishment of the Empire under the chancellorship of Bismarck, a book on Münz- und Währungsfragen (On Questions of Coinage and Currencies)
The State,

Law and Economics

in the New Empire

131, 132, 133 Three political books published by Julius Springer's sons. Although they were less politically engaged than their father, they occasionally published books by their authors when they wanted to comment on the changed social conditions in Germany which were related to the development of Germany as an industrial state. Left: The Imperial Law Against the Dangerous Efforts of Social Democracy: Discussed in relation to constitutional law. Middle: The Social Position and the Education of Shop Assistants. Right: The Social Obligations of Employers.
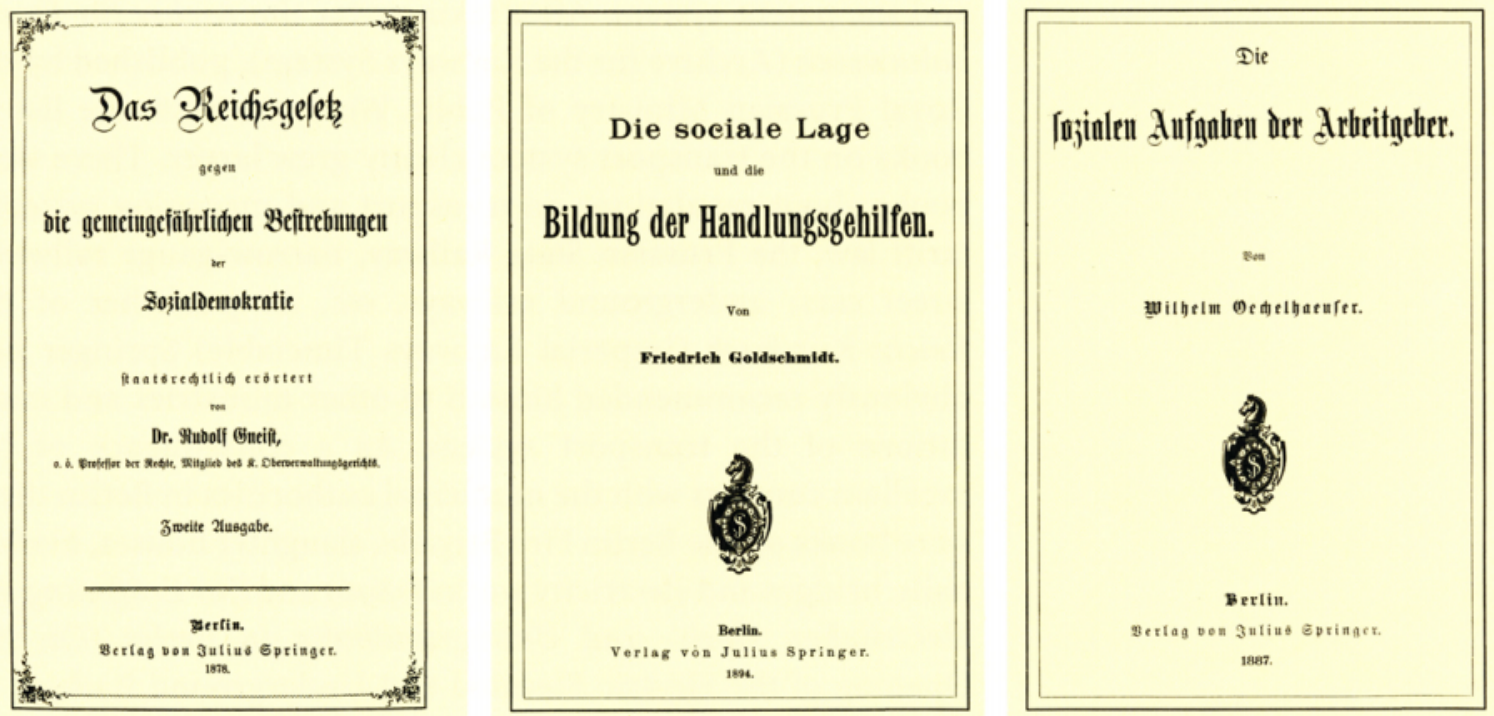


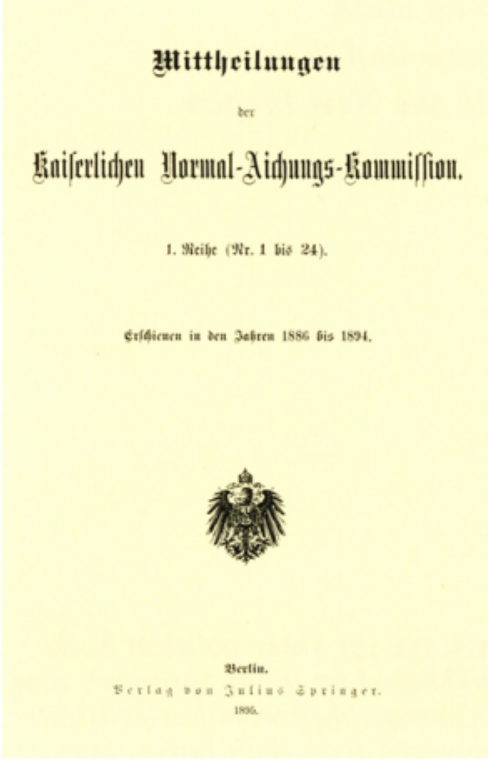

134 Cover page of the Communications of the Imperial Normal Standards Commission. After the Imperial Commission had been founded, both the Communications and numerous single publications were brought out by Springer. Some of them were translated into English.
(1871), of much interest to the public, was published. Reform des deutschen Bankwesens (Reform of the Banking System) (1872) was of the same interest to Springer as Die sociale Frage (The Social Question) (1873) and Aufgaben der Eisenbahnpolitik (Tasks of Railway Policy) (1874). That same year Springer published Heinrich Stephan's visionary talk on Weltpost und Luftverkehr (World Post and Aerial Traffic), and in 1876 Reichensperger's Kulturkampfoder Friede in Staat und Kirche (Cultural Conflict or Peace in State and Church), as well as, anonymously, Die Sozialdemokraten, was sie den Wählern versprechen, und was sie wollen (The Social Democrats, what they promise and what they want).

Publications about political questions became quite rare after Julius's death, while law and economics became more important. Rudolf Gneist's Das englische Verwaltungsrecht der Gegenwart (Current English Administrative Law) came out in 1883/84 in a new, two-volume edition. Robert Count Hue de Grais, who was President of Potsdam District from 1889, had been a Springer author since 1878. His Handbuch der Verfassung und Verwaltung in Preußen und dem Deutschen Reiche (Reference Book of the Constitution and Administration in Prussia and the German Empire) went through 17 editions (1882 to 1906), while his Handbuch der Gesetzgebung in Preußen und im Deutschen Reich (Reference Book of Legislation in Prussia and the German Empire) (1901/06) remained uncompleted after 11 volumes.

The economics programme included publications on commercial and union law, the share and cheque systems, corn tolls, and the patent system. After taking over the Archiv für Eisenbahnwesen (Archive for the Railways System), published by the Royal Prussian Ministry of Public Works in 1888, the list of books on the transport system clearly grew larger. There were books about regulations on transport and managing systems, tariff law, the Prussian State Railway, narrow-gauge railways, street cars, underground railways, etc. As publisher of the Reichs-Kursbuch (Imperial Railways Timetable) Springer had obviously recommended himself to other ministries and institutions of the transport system. As a consequence of his excellent contacts with the municipal authorities in Berlin there were books on the Berlin Fire Brigade, slaughter houses, market halls, bridges and electricity works (1896) and Zur Eröffnung der elektrischen Hoch- und Untergrundbahn in Berlin (On the Opening of the Electric Elevated and Underground Railway in Berlin) (cf. p. 91). 
Efforts to standardise weights and measures, which found their first legal basis in a law of the North German Union, increased in significance after the founding of the Empire, and in 1884 led to the establishment of the Imperial Normal Standards Commission whose bulletin Springer published from 1886 onwards. A new branch within the firm grew out of this bulletin, the "sole official publication for the measures and weights system of the German Empire excluding Bavaria." In addition to this periodical Springer also took over Metronomische Beiträge ( $\mathrm{Me}-$ tronomic Contributions), which were continued from 1895 onwards as Wissenschaftliche Abhandlungen der Kaiserlichen Normal-Aichungs-Kommission (Scientific Articles of the Imperial Normal Standards Commission). Within a period of 30 years this rather motley group of publications on state, law, economics and transport had grown to nearly $20 \%$ of the total production.

$S_{p}^{p}$ pringer's schoolbook programme, begun in the 1860 s (see petition and prices had to be tightly calculated. Books became profitable only when they had become well established and had to be reprinted - little different from today.

In the middle of the 188 os Springer had 39 schoolbooks in the programme: half of them appeared after the death of Julius. Ferdinand in particular was busily expanding this part of the list. However, the introduction of a new text had become more difficult. In earlier times, it had been possible to count on official recommendations, but now ministries and senior teachers in the states of the federation were no longer ready to give such endorsements. An invitation to recommend a particular schoolbook would be declined as a matter of principle with almost verbatim repeated phrases, namely that "the initiative in the purchasing of textbooks should be left to the teaching staff of the teaching institutions." This forced the publishers to write individually to the various schools. This not only generated a voluminous correspondence, but was also rather expensive, because "samples" were now widely asked for. It was difficult for the publisher to judge whether there was serious interest or the school was merely scrounging for books. Ultimately requests for free copies became so burdensome that the Association of Publishers of Schoolbooks proposed in 1910 "rules for the free delivery of school-, examination- and desk-books" to which within a short time 200 (!) publishing houses agreed. 


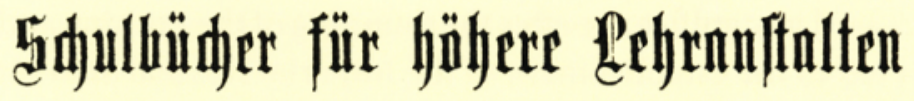

\section{(Émglirin.}

Onomatifi der englifłen Spradie zun (Siebraud)e neben ber (srammatif, enthaltend ein Bofabular nad) neuen Primżipien und einen $\mathfrak{A} b r i \tilde{\beta}$ ber mifienjđajatlidjen $\mathfrak{B}$ ortfumbe. $\mathfrak{B}$ on Dr. N. Dihm, Dberlehrer an ber Realjdule I. D. am

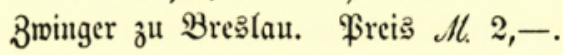

Englisches Lesebuch. Zum Gebrauche an höheren Lehranstalten mit sprachlichen und sachlichen Ammerkungen und einem Wortregister. Von In. J. B. l'eters, Olserlehrer an der höheren Bürgerschule zu Bochum. Zweite vernuelinte Autl. Preis M. 2,20.

Grammatik ber englifaen Spradje nebjt methodijdem übunģ̌

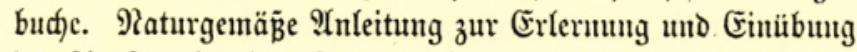

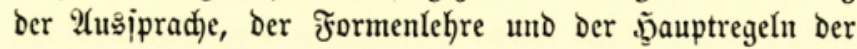
Enutar. Für ben (Eebrand in Sdjulen mie aud) für ben Eelbjtunterrid)t. Şon Dr. 9iudolf Sonucuburg, Direttor

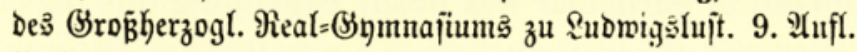
ظrcis $\mathcal{H} .2,80$.

An Abstract of English Grammar with ExaminationQuestions. Partly compiled from Adams Angus, Allen and Cornwell, Iatham, Morris, Murray, Smart, Webster and others. By. Dr. Rudolf Somneulurg. 3. Aufl. Preis dl. 1,20 .

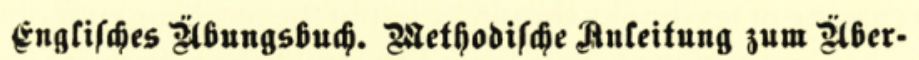
leţen aus dem Deut/ąen in bas Englifąe. Şon Dr. ९ubolf Sounenburg.

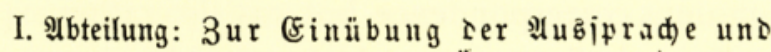

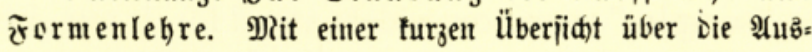

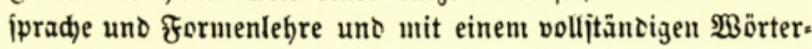
bude. Freis th 2,-.

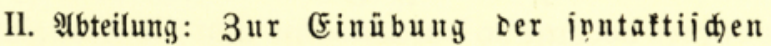

135 An 1883 prospectus listing Springer schoolbooks for secondary schools. Altogether 39 titles in this category were available at that time.

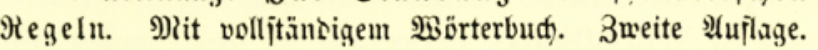
舟reiz $\mathscr{M}$. 2,- 
By this time, however, Springer had already discontinued this line of publishing, because it had become ever more difficult. No new titles were added, but reprints and new editions were continued. Among these were Griechische Formenlehre (Textbook of Greek Forms) by Franke; Hauptregeln der griechischen Syntax (Main Rules of Greek Syntax) by Seyffert, now edited by Albert von Bamberg; and books on English grammar by Sonnenburg and officially endorsed in Austria. These were all books originally published by Julius Springer. In the 1880 s an attempt was made to restart the programme. The three-volume Lehrbuch der französischen Sprache für die untere Stufe höherer Lehranstalten (Textbook of the French Language for Lower Forms in Higher Learning Institutions) was published in $1886 /$ 89 , and a history textbook for the lower and middle forms in three instalments in $1888 / 89$, followed in $1881 / 87$ by six instalments for the upper forms.

A new start in the natural sciences, promoted by the editors of the Zeitschrift für den physikalischen und chemischen Unterricht (Journal for the Teaching of Physics and Chemistry) brought the list to over 20 titles, but none went into a second edition. Although special issues of the Zeitschrift, edited by Poske, Höfler and Grimsehl, continued until 1937, Springer had withdrawn from actively publishing schoolbooks at the turn of the century. This, too, was the result of specialisation. Subject areas which had been developed strongly were dropped as other publishers concentrated their efforts in those directions.

$\mathrm{W}$ ith the acquisition of the Forst- und Jagdkalenders (Forestry and Hunting Calendar) in 1858 (cf.p. 63) Julius had begun systematically to widen his publishing programme to include forestry. He succeeded in recruiting teachers at the Forestry Academy in Neustadt-Eberswalde as authors and, after 1867, also those at the newly extablished Academy in HanoverMünden. A Zeitschrift für Forst- und Jagdwesen (Journal for Forestry and Hunting) and a Jahrbuch der preußischen Forstund Jagdgesetzgebung und Verwaltung (Yearbook of Prussian Forestry and Hunting Legislation and Administration) provided him with regular contact the foresters, which he further strengthened in 1874 by an annual report of the proceedings, the Berichte über die Versammlung deutscher Forstmänner (Assembly of German Foresters).
136 (Bottom) From 1867 onwards Paul Parey (1842-1900) was in charge of a publishing firm which had been founded in 1848. In 1881 it took his name. By specialising in agricultural and forestry sciences, garden construction, hunting and fishing his firm became the leader in these areas. He and his successors never failed to be good colleagues to Ferdinand Springer and his successors.

Forestry

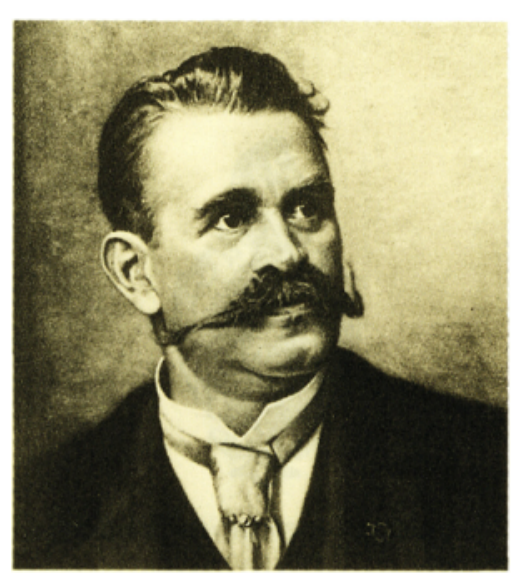


In 1877 , when Julius Springer died, forestry was the firm's largest publishing area, by number of titles. Later it somewhat stagnated and ultimately there was an absolute decrease in title numbers. During the decade from 1897 to 1906 forestry with agriculture was fifth by number in the production list. However, the position by turnover was much lower, because most of the books were small and only a few were reprinted. Authors who had once been active were no longer very productive and Paul Parey, a rival publisher, succeeded in attracting the new generation of forestry experts to his firm.

As with schoolbook publishing, a change of leadership within a publishing house can have significant consequences. If a publisher lacks affinity for an area and those most active in it, existing contacts set up by his predecessor gradually weaken. An ever-watchful competitor can then successfully enter a territory that a publisher may for long have considered his own.

The Springer Logo

Tn 1881 Springer-Verlag originated a logo that, with a few modLernising alterations, is still imprinted on all its title pages and promotional material. It expressed the self-confidence of the second generation of publishers, who from now on could complement the firm's name with a memorable design in its books and journals. It was drawn by the architect Wilhelm Martens, a friend of the Spinger family, who had also supervised the reconstruction of the firm's premises in Monbijouplatz, and was based on a sketch by his father-in-law, Martin Gropius (1824-1880), a famous Berlin architect, pupil of Karl Friedrich Schinkel and director of the Berlin College of Fine Art (Walter Gropius, architect founder of the Bauhaus, was one of his nephews).

The founder's initials, JS, are surrounded by the firm's motto Alle Zeit wach (Be ever alert), formulated by Ferdinand Sprin-

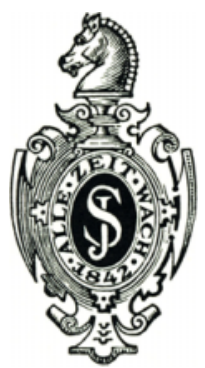

The Springer logo in its first design of 1881 . ger, and by the year the publishing house was founded. This logo was first imprinted on a book by Otto Schmidt Neuere Bauformen des Ziegel- und Holzbaues (New Forms of Construction of Brick and Wooden Buildings). The horse's head is a play on Springer, the German name for the knight chess-piece, and the fact that both Julius and his two sons were chess enthusiasts, regularly meeting their friends for play at the Café Belvedere in Berlin. Julius always had two boards open at home for games by correspondence, one with the bookseller Eduard Müller in Bremen where his son Ferdinand had worked as assistant for a 


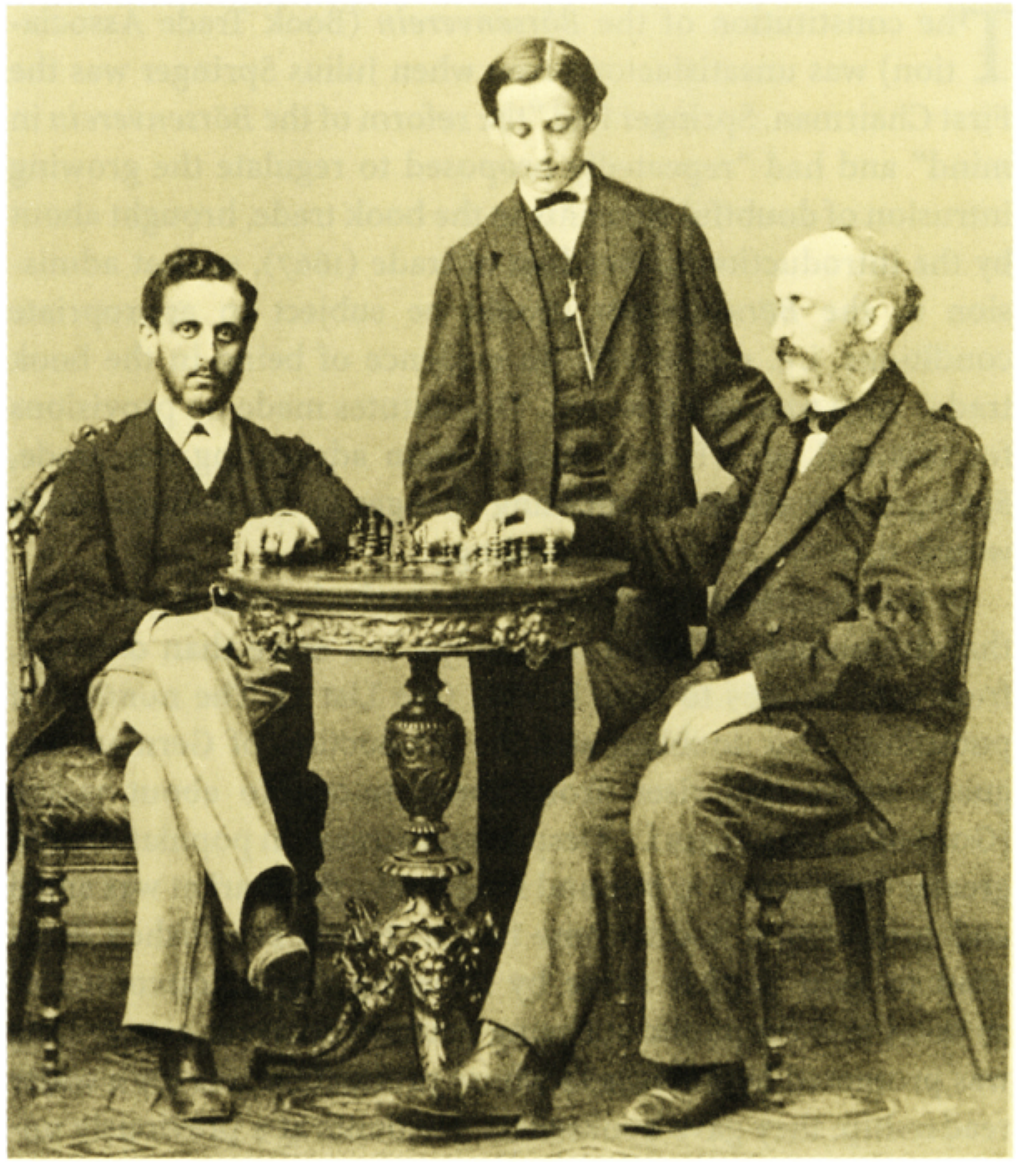

few months in the spring of 1867 . The moves were entered in the margins of the Naumburg advertising journal. [WITTMANN: 232]. The other board was for games with the Berlin bookseller George Winckelmann. The moves were exchanged via the Berlin Book Ordering Centre.

Julius Springer must have been a rather good player. He had once won against the famous chess-master Gustav Richard Neumann who, together with Adolf Anderssen, edited the Neue Berliner Schachzeitung (New Berlin Chess Journal), published by Springer (Springer's winning game was published in the journal during its second year). Altogether, he published 16 books on chess, in addition to Baltische Schachblätter (Baltic Chess Papers) (1889-1902), the best known having been Theoretisch-praktisches Handbuch des Schachspiels by Dufresne.
137 Julius Springer at the chess ta ble with his sons Ferdinand (left) and Fritz (middle), in about 1866.

138 Title page of History and Literature of Chess, one of a total of 16 books and two journals on chess published by Springer over the years.
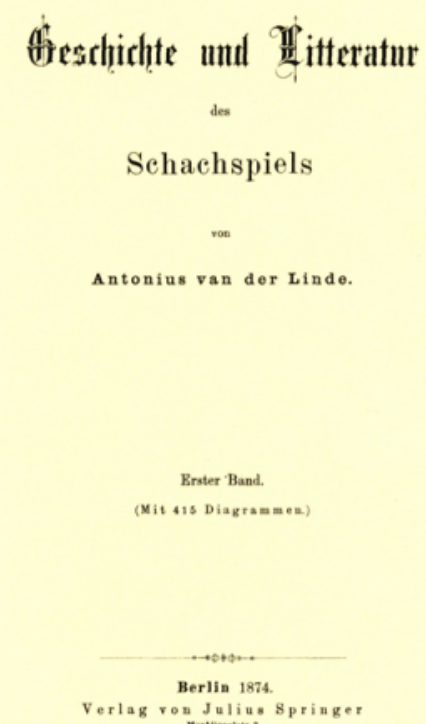
Changes in the Market $T$ he constitution of the Börsenverein (Book Trade Association) was unsatisfactory even when Julius Springer was the First Chairman. Springer had "the reform of the Börsenverein in mind" and had "repeatedly proposed to regulate the growing intrusion of doubtful elements in the book trade, brought about by the introduction of freedom of trade (1867), so that admission to the Börsenverein should be subject to appropriate conditions, i.e. not merely on evidence of being in the book trade" [GoLDFRIEDRICH: 513]. The statutes made no provisions for this and, as a liberal businessman advocating free trade, Springer was averse to initiating changes in the statutes which would regulate book trade dealings.

In the meantime conditions had reached a turning point in that the number of retail bookshops had more than doubled, from 1963 in 1865 to 3884 in 1885 (see List 5). The number of publishers also doubled, and the production of German-language books had risen from about 10,000 to about 15,000 [GOLDFRIEDRICH: $419 \mathrm{f}$.]. Despite an increase in population and greater willingness to buy and read books the market was small and competition had become fiercer. Newly established firms tried to gain market share by lowering prices, discounts of $20 \%-25 \%$ to the public not being unusual. Such cut-rate pricing was promoted by publishers whose production was for a wider readership: they gave booksellers discounts at a previously unheard of level.

Price cutting had occasionally occurred at earlier times, but to only a limited extent and mostly only for local cash sales. After

\begin{tabular}{|l|l|l|l|l|}
\hline Year & $\begin{array}{l}\text { No. of } \\
\text { publishers }\end{array}$ & Bookshops & $\begin{array}{l}\text { Book } \\
\text { production }\end{array}$ & $\begin{array}{l}\text { Population } \\
\text { (in millions) }\end{array}$ \\
\hline 1865 & 668 & 1963 & 9661 & 37.6 \\
1870 & 866 & 2254 & 10108 & 40.0 \\
1875 & 803 & 2670 & 10561 & 42.7 \\
1885 & 1340 & 3884 & $?$ & 46.9 \\
1890 & 1665 & 4526 & 15714 & 49.2 \\
1895 & 1428 & 4984 & 19574 & 52.3 \\
1900 & 2192 & 5405 & 19727 & 56.0 \\
1905 & 2022 & 6480 & 23171 & 60.3 \\
\hline Increase & $230 \%$ & $203 \%$ & $140 \%$ & $60 \%$ \\
\hline
\end{tabular}

List 5 Between 1865 and 1885 both population and book production increased by about $25 \%$. But the number of publishers and bookshops more than doubled in the same period. The growth differential created conflicts [Figures after Stemmle: pp. 175 and 181 ] 
Statt 44 Mk. für netto 38 Mk., elegant in Halbfranzband gebunden für $40 \mathrm{Mk}$.

Handbuch der pharmaceutischen Praxis. 1880 erschicen:

2. Ausg. Dr. Hermann Hager. Mit zuhlreirhen, in den Text gedruckten Holzsehnitten. Als werthvolle Gratisbeigaben

im Werthe von 36 Mark fuge jedem bestellten Exemplare bei:

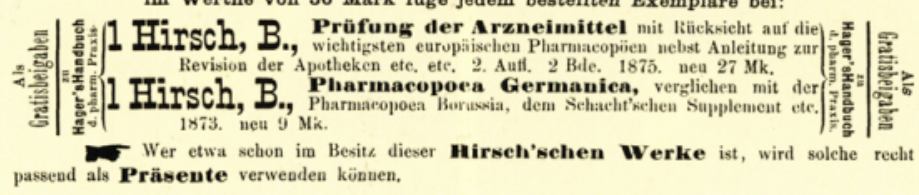

new postal parcel tariffs had been introduced in 1874 (a $5 \mathrm{~kg}$ parcel now cost only 50 pfennig), cut-rate pricing flooded the market. It was now possible to sell more expensive books by post, without charging postage, and give the customer a discount even when the publisher's discount was quite sizeable. The Leipzig booksellers profited particularly, because they could obtain all Leipzig publishers' books - and this meant almost all publishers of any importance - free of postage.

Springer-Verlag with its specialist publications was hardly affected by all this. It gave a $25 \%$ discount on individual sales or $30 \%$ to $33 \frac{1}{3} \%$ on sales of a significant number of the same title. In exceptional cases it granted "quantity lot" terms, i.e. one book in seven or ten books was provided free. This gave little incentive to cut-rate sellers, particularly since they rarely had addresses of potential buyers in the sciences. In one case a mail-order bookseller had offered postal sale of Hager's Handbuch der pharmaceutischen Praxis in soft cover for 38 mark instead of the list price of 44 mark, and half-leather for 40 mark instead of 50 mark. Single cases of this kind were hardly a reason for Springer-Verlag to argue the matter, particularly since neither brother had an official position in the Börsenverein. However, as members of the council of the Berlin Booksellers Corporation they were actively engaged in its affairs, and knowing the special problems of the Berlin market they were soon in the middle of a vehement discussion.

$\mathrm{T}$ he reforming moves of the Börsenverein began under Adolph Enslin, who had succeeded Julius Springer as First Chairman, the discussion continuing for over ten years. The central point was that a new statute was to oblige all members to
139 Cut-price offer, by a mail order bookseller, of Hager's Handbuch, together with a choice of two other books for free. 
140 Adolph Enslin (1826-1882) was Springer's successor as chairman of the Börsenverein. His endeavours for its reform, like those of his predecessor, were without significant effect.

141 Adolf Kröner (1836-1911) completed the transformation of the Börsenverein into a trade association. He was called the "Bismarck of the German book trade".
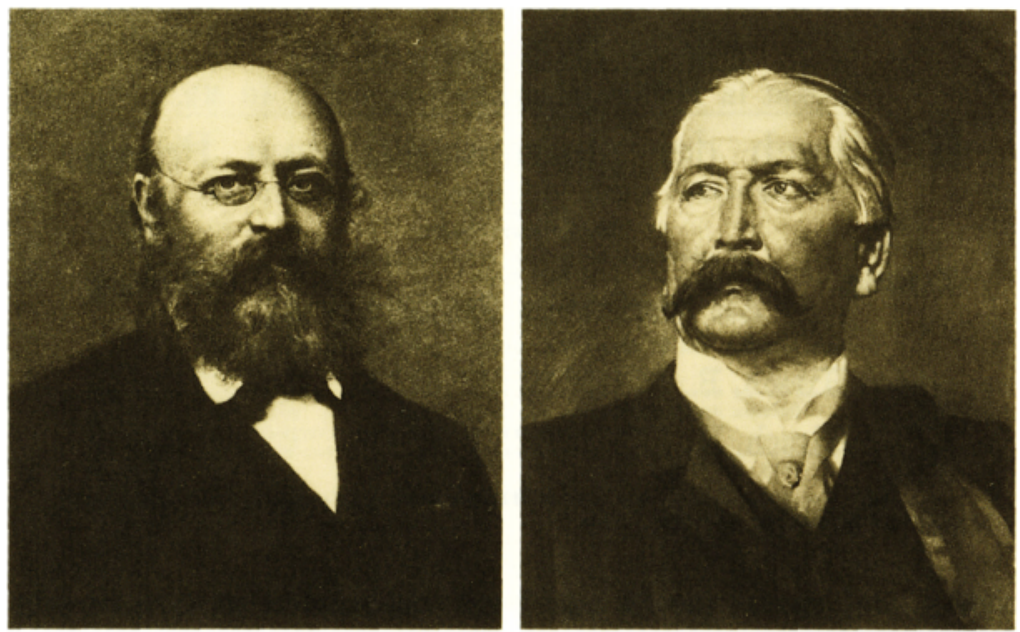

keep to the list price as fixed by the publisher. They would not be allowed to supply books to retail booksellers who sold at lower than list price. Similarly, publishers would not be allowed to sell direct to the public at less than the fixed list price.

Under Adolf Kröner (First Chairman 1882-1888 and 1889 to 1892) an Extraordinary Board for the Revision of the Statutes (of the Börsenverein) was in session from June 30 to July 2,1887 . It consisted of six elected council members: Albert Brockhaus, Alexander Francke, Wilhelm Koebner, Theodor Lampart, Otto Mühlbrecht, Justus Neumann, Ferdinand Springer, Emil Strauss and Franz Wagner [BBL.1887, p.4450f.]. At the start it was stated: "Herr Springer is against including the fight against cut-price sales in the responsibilities of the Börsenverein; he disputes any real and lasting success; and he does not consider the Börsenverein to be entitled to exclude present members, who have not voted for the new statute, and deprive them of their special rights."

It was obvious that Ferdinand Springer had been voted onto the Extraordinary Board as the most prominent opponent of what later became known as "Kröner's Reform," and it was fair that Springer's opinion should have been read out in full. While Springer well knew that the other Board members did not share his opposition, he nonetheless wanted to vote for Kröner's proposals, "other than minor editorial changes," except on two points. First, a publisher should be required to supply books to a bookseller. Secondly, if it came to a vote, e.g. on changes in the statutes, the right to vote was not transferable. In the course of the discussion a more important point emerged, namely Sprin- 
ger's advocacy for bulk sales to "official bodies, institutes, societies etc." by the publisher at specially reduced prices.

Springer pointed out that in his contract for the ReichsKursbuch (Imperial Railways Timetable) there was a clause that "the entire Prussian Railways administration was to receive the timetable for exactly the same price" as the book trade [REFORMBEWEGUNG II: 488]. He also gave other examples, but did not mention publications of societies and associations whose members received them at sometimes only one-third of the list price. Springer asked for the addition of a new statute in the special regulations, because he did not want to have an exception made for his firm. He was reluctant "to do something that is directly against the statute, if the Board were to say that this is a "special case which we will overlook. We do not wish to be sued" [REFormBeWEgungir: 491]. The Board relented and a clause was added to $\$ 3.5$ that publishers are entitled "in exceptional cases to sell larger numbers of copies of a work published by them to official bodies, institutes, societies and such like at specially reduced prices, either by themselves or through retail booksellers as intermediaries." The last half of the last clause constituted a compromise. It was to remind publishers that as a rule supplies were to be obtained via a bookshop.

$\mathrm{C}$ omplaints that book prices are too high are nothing new. When Leibniz wrote his Promemoria he complained that booksellers "cared little about the common good and almost solely about their own" [WIDMANN: 140]. The argument flared up in 1903 when the Leipzig political economist Karl Bücher published a memorandum, on behalf of the Akademische Schutzverein (Academic Protection Society), about the German book trade and the sciences and humanities [BÜCHER], which quickly had to be twice reprinted. In Bücher's view the Börsenverein, through the Kröner Reforms, had set up a price cartel, retailers and commission agents serving as connecting links, which raised prices unnecessarily.

Never before had questions about the book trade been of such lively concern to the general public as through the discussion of Bücher's expositions. Finally the Imperial Office of the Interior intervened and invited the warring parties to "Contradictory Negotiations" (i. e. negotiations between opposing sides) in Berlin from April 11 to April 13, 1904. Officials, scholars and librarians stood opposite the council of the Börsenverein with

Ferdinand Springer

Amidst the "Battle of Books" 
invited publishers and retailers. Ferdinand Springer who, like his brother, did not belong to any committee of the Börsenverein, was presumably invited as a convinced "free-trader." His basic views were known and the clarity of his arguments was appreciated. To the great surprise of the participants it was soon clear that Springer had come to be a thoughtful defender of Kröner's reforming proposals. His basic views will be presented here because they clearly mirror his entrepreneurial philosophy and self-confidence as publisher [KontradikTorische VerHANDLUNGEN: 285 f., $404 \mathrm{ff}$.].

Up to this time he was said to have distanced himself from the booksellers, as seemed to be confirmed by the "Springer Paragraph" (see p.141f.). Springer described in detail his direct sales. He said that it was a peculiar feature of his publishing house that the direct dealings with the public had developed in this way:

I am, as you know, a specialist publisher for various, mainly technical sciences and am fortunate in also publishing the leading periodicals in these areas, some of which also dominate the labour market of the corresponding industries. If I now advertise my publications in my own journals, a more or less large number of orders by readers of these journals will naturally come direct to me; and no engineer, or pharmacist, etc. would understand it, if I were to refuse to send him the advertised books, while I accept his "position wanted or vacant" advertisement and charge him direct [KV:288].

He had at first "with some reluctance, but then giving in to necessity, allowed this direct business to emerge and fructified it

142 The first statutes of the Börsenverein in 1887 were accepted after much disputation. The version of 1903 was viewed by the "Academic Protection Society" as confirming the existence of a bookseller cartel.

143 The memorandum The German Book Trade and the Sciences by Karl Bücher (1847-1930), a political economist in Leipzig, caused fierce public controversy. It was called, with double meaning, the "Bücher Fight" [Bücher = Books].

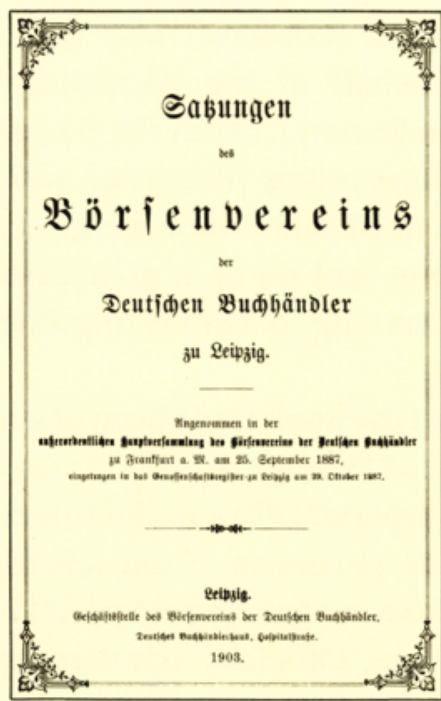

Der Deutifie Butdfiganter unto bie 2 siijentidaft.

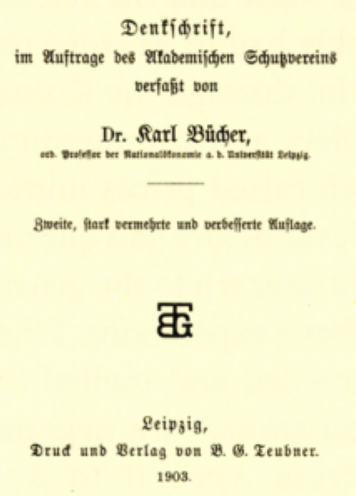


as much as possible. But I remark here that I had made it a basic principle never to compete with retail booksellers through lower prices: no discount was ever given!" Nor did Springer make a secret of the volume of his direct sales: $60 \%$ of books and periodicals were distributed via the book trade, while $40 \%$ went to the public direct or via the Postal Journal Office [KV:288].

Springer had enquired within his firm whether a real advantage remained for the business, whether in fact one could lower book prices with still greater expansion. "I can tell you that this is not possible. The publisher's direct business with the public, if it is at all possible," could be achieved in only one of ten cases. Apart from the additional work it would greatly increase costs, the number of personnel and also some additional furniture or equipment. If it were conducted with a certain amount of accommodation it would cause such losses "that it would not be profitable to meet the full costs of direct advertising. To me the cost of such advertising is relatively low." If, however, he was now to pay for the insertion of advertising leaflets in his own journals, the business would trade at a loss. Springer thought it was impossible that the majority of the German book trade could sell direct to the public. "I can do it, a few specialist publishers that direct themselves to particular, circumscribed circles can do it; but the German scientific publisher in general cannot do it. I ask you to be convinced that this information has a sound and safe basis." [KV: $288 \mathrm{f}$.]

The Akademische Schutzverein and its spokesmen also complained about the large number of retail bookshops. Springer conceded that there was a large number, "but to regulate it is as difficult as to produce cheap books with high royalties, high production costs and low sales. It is the present conditions which make for so many retailers and cause the numbers to continue to increase." It was above all due to the unequal needs of publishers, because the scientific publisher, the technical publisher, the belletristic publisher ${ }^{30}$ had quite different requirements. While Springer-Verlag could manage with 600 or 800 firms in Germany, ${ }^{31}$ belletristic publishers had quite different needs with their literature, and for them there could not be enough outlets. They "must distribute not only through the real retail booksellers, but also smaller businesses; innumerable 'book suppliers' were indispensable for them" [KV:405f.]. As there were so many retailers and many publishers could not do without them, it was necessary to keep them viable. It could not, 
144 Springer's announcement, in 1904, of his sales conditions. These were rather rigid and seemed to make cut-price sales impossible. But a lawsuit forced Springer to drop this prohibition and, as a result, to resign from the Börsenverein for some years (see text, p. 148).

\section{Gefälliger Beachtung empfohlen.}

Meine Sendungen erfolgen, wenn nicht ausdrücklich anders verabredet, unter folgenden Bedingungen:

I. Auf $\mathrm{Ihr}$ Verlangen fest gelieferte Werke zurückzusenden sind Sie nicht berechtigt.

II. Sie sind verpflichtet, als $\mathrm{Neuigkeit}$ und à condition gelieferte Werke meines Verlages auf mein ausdrückliches Verlangen innerbalb 3 Monaten (nach Datum des Zurūckveriangens) zurūckzusenden. Nicht in dieser Zeit Zurückgesandtes betrachte ich als $f$ est bezogen.

III. Sie sind verpflichtet, mir zur Oster-Messe des kommenden Jahres von meinen Lieferungen alles dasjenige zu bezahlen, was Sie bis dahin nicht zurückgesandt oder mit meiner vorhergehenden Genehmigung zur Disposition gestellt haben.

IV. Falls Sie aus irgend einem Grunde Ihren Verpflichtungen nicht nachkommen, so bin ich berechtigt, Abrechnung über das Ihnen auf neue Rechnung Geliaferte zu veriangen, und zwar derart, dass Sie zur Rǔcksendung Berechtigtes sofort franko mit der Post an mich zurückzusenden, nicht $\mathrm{Zurúckgesandtes} \mathrm{aber}$ sowie fest Geliefertes innerhalb 4 Wochen an mich zu bezahlen haben.

Bei Büchern, für welche nicht besondere Bar- und Partiebedingungen bestehen, gewähre ich gegen bar keinen höheren Rabatt als in Rechnung.

$\mathrm{Zu}$ direkten Sendungen bin ich gern bereit; ich stelle das Porto in laufende Rechnung und berechne keine Emballage. - Eine Verpflichtung für direkte Sendungen kann ich bei Neuigkeiten- und Fortsetzungs-Expeditionen nicht übernehmen.

Direkte Sendungen an Firmen, mit welchen ich nicht in offener Rechnung stehe, mache ich nur, wenn der Betrag eingesandt oder Post-Nachnahme gestattet ist; andernfalls expediere ich durch den Kommissionär.

Ich führe ein Giro-Konto bei der Reichsbank und mache darauf aufmerksam, dass jede Reichsbankanstalt Zahlungen für meine Firma entgegennimmt.

In Leipzig halte ich kein Auslieferungslager; nur das (amtliche) Reichs-Kursbuch wird in Leipzig (bei Herrn F. Volckmar) mit $25 \%$ gegen bar ausgeliefert.

\section{Julius Springer.}

therefore, be right to support some retailers and at the same time to deny others the possibility of existence.

It would naturally not be easy to differentiate between retailers who sell many books for a given publisher and those who only occasionally sell its books. But a distinction must be made. Retailers who work actively for a publisher's list are likely to be given preferential terms, while the mere "book obtainer" would at most get the normal discount, which would not be enough to provide a discount for the customer. A book costing 3 mark, supplied to the retailer for 2.25 mark, could not bring excessive profit for the seller. "Be assured that the publisher himself 
watches out for this. We also like to earn, we do not spend needlessly and certainly don't grant discounts unnecessarily" [KV: 407].

Springer openly admitted that he did not open accounts for retailers who only occasionally placed orders with him, but directed them to cash orders via third parties. "In this way I have succeeded in reducing to a relatively small number those retail booksellers with whom I have, as we say, running invoices and those who receive my new publications. Because of the peculiar nature of my publishing activities, there are now, in the larger appropriate towns, only a few firms that actively promote my interests, and therefore also do good business."

Springer-Verlag was also cautious with supplies on commission. Retailers who failed to sell even a quarter of the books supplied to them on a right-to-return basis were no longer sent books on commisssion.

Scientific authors complained particularly loudly that they considered book prices were too high. Springer recommended that they should insist on lower prices with their publishers, "make definite stipulations; let them have books only on condition that the price is as you wish it, i. e. attempt to hand them over on this condition, and if your publisher cannot do it, seek another publisher. Competition among publishers is so great that they will see if there is any way at all of meeting your demands. Why don't you try it? But I fear that you will find that you will not achieve any significant changes in the book price, despite the competition which publishers have generated among themselves - they have not formed a ring against authors. It is simply not possible" [KV: 408].

Alexander Francke from Berne, who had attended the crucial session, wrote three years later in his obituary of Ferdinand Springer: "At that time, with these candid confessions, Springer did a great service to the book trade.... For the colleagues who were present at the session, April 13, 1904 impressed itself as a memorable day for the reform movement of the German book trade" [Francke:XIX]. The Berlin publisher Adolf Behrend reported that in 1905 "the wish had become loud in influential circles of the book trade that Ferdinand Springer should be elected to the Council of the Börsenverein, with the immediate aim of making him Albert Brockhaus' successor as First Chairman when his term of office ends. For this energetic and far-seeing man, fully conversant with the conditions of the book 
145 Headquarters of the Börsenverein in the Gerichtsweg in Leipzig. It was a sign of its growing self-confidence and financial power that two famous architects of the time, Heinrich Kayser and Karl von Großheim, had been commissioned to design the building. The town of Leipzig provided the building plot without charge, a sign of its receptiveness towards the aims of the book trade and its economic importance. [Hence the Leipzig Book Fair, continuing to this day.] At the laying of the foundation stone on May 23, 1886 , the civic head of the town, Otto Robert Georgi, emphasised the spiritual forces that guided the book trade and its "so powerful" Association.

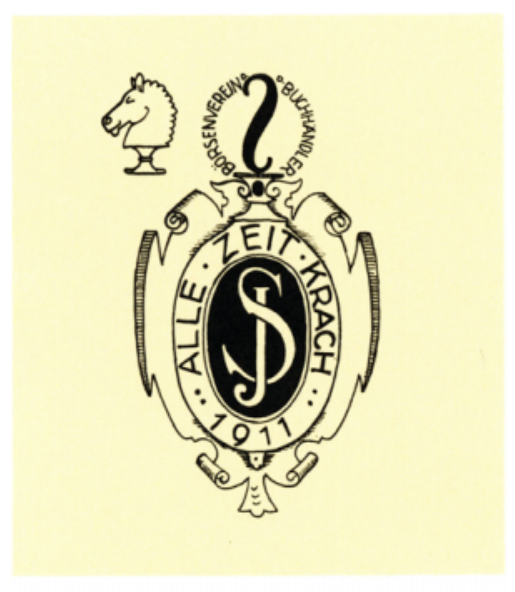

Fulius tehre zurûd, es it alles vergeben. Dein B.D.d.D.B.

146 Humorous variant of the Springer logo in a print of 1911. [Alle Zeit Krach, instead of wach - i.e. "always a row" instead of "ever alert"; Underneath it: "Come back Julius, all is forgiven, Yours B.V.d.D.B." = Börsenverein der Deutschen Buchhändler].

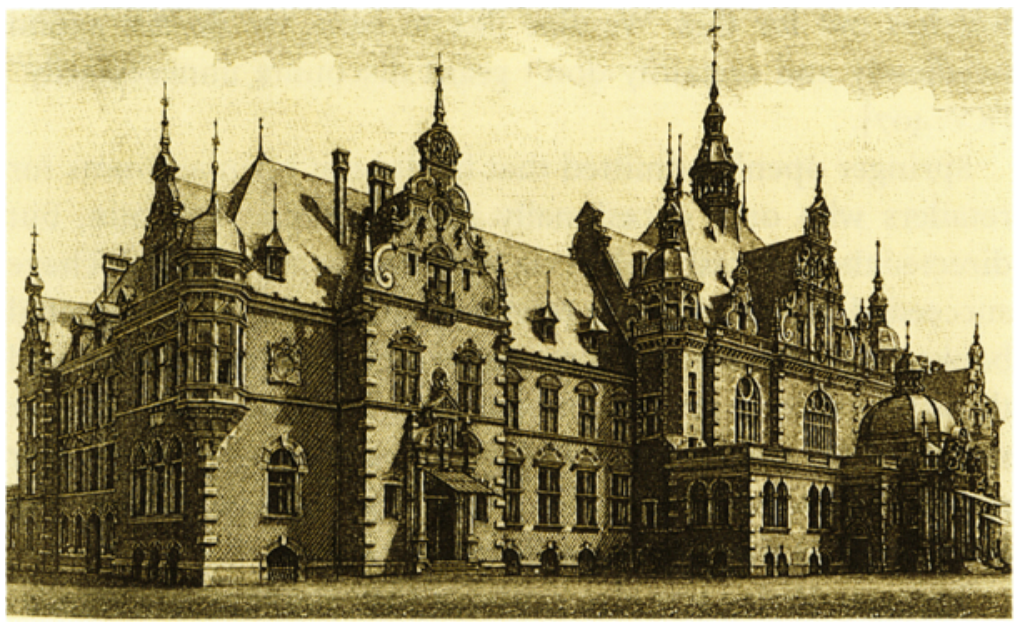

trade, the position was very attractive, but nonetheless he declined the candidature. With overly harsh self-criticism he had concluded that he had to fear that his lively temperament would be a hindrance and that he was not enough of a diplomat to fight the battles to be expected." 32

Springer strongly supported the Börsenverein in its fight against cut-price book selling after the memorable Berlin session. Nor did he avoid going to court, in 1905, when the large Leipzig antiquariat Gustav Fock, known at home and abroad for his price cutting, offered newly published Springer books in his catalogue at reduced prices. The firm pursued the case on the advice of the Börsenverein and at first won it. But on appeal Springer's case was rejected for the reason that "inferior goods" had been supplied. This lowering of value had consisted of Springer-Verlag marking all copies supplied to the antiquariat with nearly invisible pinpricks at a certain place in order to catch the guilty party. Springer-Verlag's sentence was that it had to supply the antiquariat, according to the statutes of the Börsenverein..$^{33}$ Promptly, in November 1909, the firm and its owners cancelled their membership of the Börsenverein so as not to be bound by its statutes. At the same time they announced to the book trade that the firm would rejoin the Börsenverein as soon as it abolished the statute about the obligation to supply. This happened with the new Statute on Book Trade Relations of May 20, 1910, its Clause 2 concluding: "There is no obligation for book traders to supply to each other." The hatchet was buried, but Springer-Verlag and its owners did not rejoin the Börsenverein until October 1911. 
A the time of Julius Springer's death in 1877 the firm had been in existence for just 35 years. During that time it had produced an average of 37 books and three journals yearly. All this was accomplished with only four employees: a jack of all trades assistant, an accountant who also worked in the post room, an apprentice and a packer [MENZ (2):187]. In those days all work typically to do with publishing was still a matter for the "chief": judging manuscripts, correspondence with paper suppliers, printers, engraving firms and book-binders. The publisher himself wrote the advertising copy, he corresponded with the retailers and also kept the accounts. His assistant was called in for less important work. After his son had joined he was allowed to undertake tasks which had previously been exclusively for his father.

Until the last days of his life Springer himself did the accounts for the Leipzig Book Fair and the correspondence with retailers. Again and again his family asked him to leave these matters to others, for example to his son. His colleagues in fact sometimes joked about his way of concerning himself with every detail. But Julius Springer wanted to keep his finger on the firm's pulse.

Soon after Ferdinand Springer had taken over in April 1877 he divided the responsibilities with his younger brother Fritz. The firm quickly began to grow and more personnel was engaged. The numerous new journals in particular made a larger staff and more specialisation among it necessary. Between 1880 and 1882 journal production had gone up fourfold to 238 issues annually, and new ones were added every year.

Julius had handled production without great expense: he would give a manuscript to a printing firm and ask for a cost estimate. Format and print-run were given and a notion of the layout transmitted. It was often enough to point to a previously produced book. The printer would give his price for typesetting, printing and paper, as well as for binding and cover. Details of production, such as type size for the text and the footnotes, as well as the typography of the title page and the cover, were left for him to work out. There were some well-established customs for this, which the printer observed and the publisher usually accepted silently.

The number of manuscripts increased markedly under the new direction, as did illustrations, because the technical books and journals needed them. Since the authors' drawings were not normally ready for printing, they had to be redrawn for the xylographer (wood-cutter). Before this work could begin the
The Emergence of Specialised Sections Within Springer-Verlag 
revised drawings had to be approved by the author. If this was omitted, as frequently happened, the wood block had to be done again. This was expensive and time-consuming. In the end a decision had to be made whether a zinc engraving would suffice for an illustration or if an expensive wood engraving was essential. All this needed a knowledge of technical and financial matters. Line drawings were produced as zincographs which, depending on the degree of difficulty, cost $4-8$ pfennig each. A small printing block of $30 \mathrm{~cm}^{2}$ cost between 1.20 and 2.40 mark. This was a great deal of money when one considers that a typesetter, at that time the highest paid technical manual worker, received about 40 pfennig per hour. Large tables were preferably done as lithographs, while half-tone illustrations in the text required xylographs (wood cuts), of which a square centimetre cost between 30 and 90 pfennig, depending on the degree of detail required. Even in absolute terms this was much more expensive than offset production nowadays.

In 1886 it was decided to found a lithographic firm as punctual and qualitatively satisfactory execution of illustrations was creating difficulties. The two brothers each put in 15,000 mark as basic capital and the managing co-owner of the firm, Ludwig Keller, was to build up his capital account by depositing annually 2000 mark of the profit. The new firm, Springer \& Keller,

147 First draft of the agreement to found the "Lithographic Institution and Stone Printing" of Springer \& Keller, 1886.

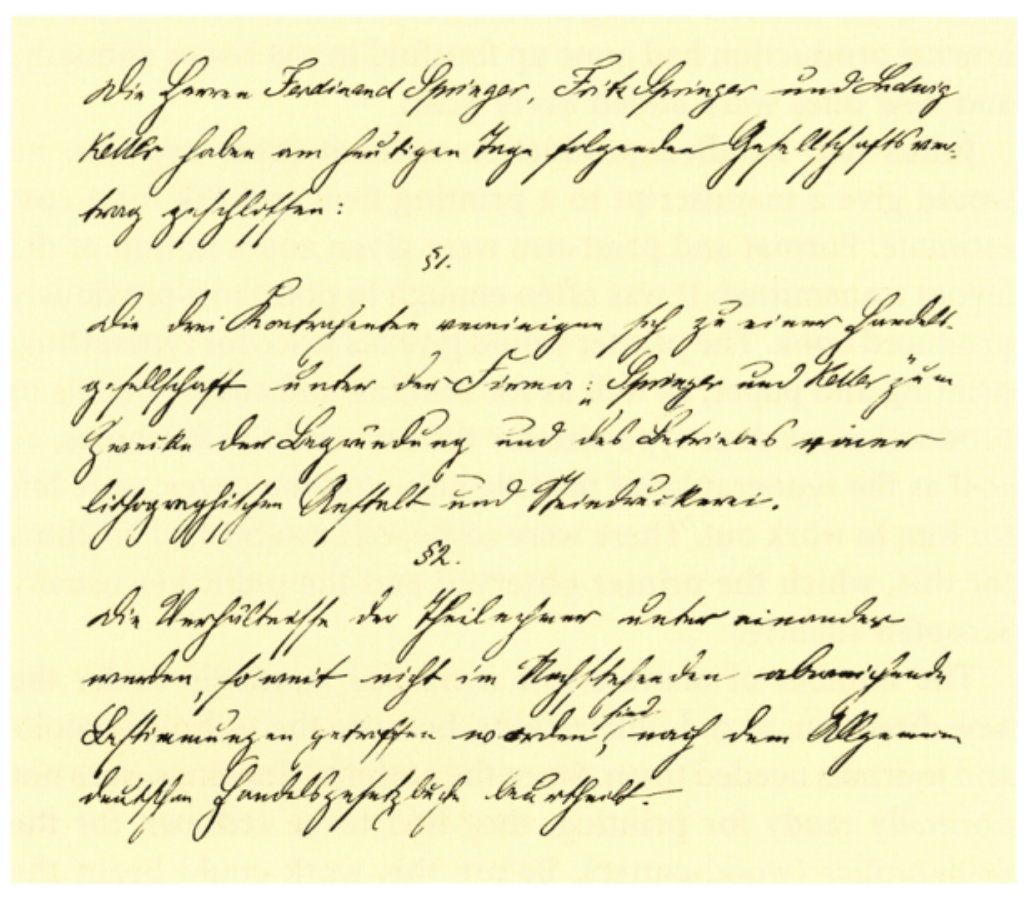


apparently did not get a lot of business, and Springer-Verlag cannot have sent much work. As a result the two brothers took out their capital and share of the profit from July 1, 1895 and left it to Keller to carry on with the business. The rapid progress made with metal etching probably played a part in this decision. Half-tone engraving, invented by Georg Meisenbach in 1882, improved rapidly, and lithography and wood cuts gradually became less important for illustrating technical books.

The first person in charge of production at Springer-Verlag was Carl Grosse (1849-1913), appointed in 1882. He also had to work with Keller (see above). He had previously worked at a printing company where he had also learned and practised double-entry book-keeping, which he was asked to introduce into Springer accounting. As one can see, despite the need for specialisation more widely experienced employees were greatly valued.

Other parts of the firm also expanded. As the number of titles grew, storage capacity and the department dealing with filling daily orders for books and journals also increased: there was more billing, book-keeping and reminders together with ever more enquiries from booksellers. In addition, as has already been mentioned, labour-intensive direct selling expanded (cf.p. 145). An advertising section had to be set up as part of journal production, and offices had to be found for the in-house editors of Elektrotechnische Zeitschrift and Pharmaceutische Zeitung.

In 1872 , soon after Ferdinand Springer had joined the firm, a small annex, enough for two assistants, was built in the courtyard of the house in Monbijouplatz [FS: 20], but this did not suffice for long. In 1878 a stable belonging to the house was pulled down and a small, three-storey building was erected. The packing room was in the cellar, the ground floor housed four assistants, the alphabetically ordered warehousing was on the first floor, and the book bales in the loft. In 1889 the brothers persuaded their mother to leave her apartment on the first floor and to sell the premises to the firm. From then on the whole house, from cellar to loft, was filled with Springer-Verlag activities.

There were other noteworthy developments. Money payments, which in the 1870 os had still predominantly been made in cash or by bill of exchange, were now done by bank transfer. This was made much easier by the growth of business banks with closely spaced branches and the establishment of the uniformly 
148 The house on Monbijouplatz (in 1911). From 1880 the whole building was occupied by the publishing firm. At the time of Ferdinand's death a staff of 64 worked there.

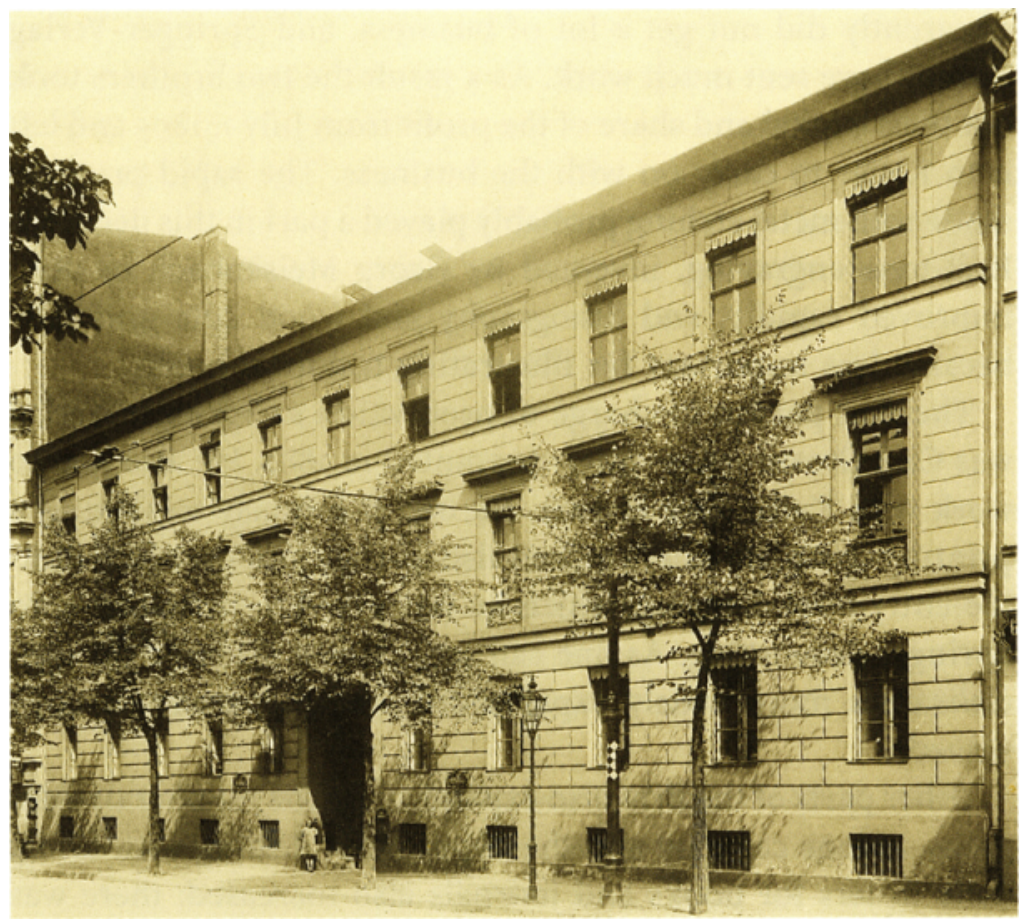

valid imperial currency. In the 1880 s Springer-Verlag opened giro accounts with the Reichsbank and Deutsche Bank. That the firm decided so early to subscribe to this new method of exchange was probably on the advice of Georg Siemens, cofounder and director of Deutsche Bank. He was not only Ferdinand's cousin but also his landlord in Tiergartenstrasse.

In the spring of 1882 a telephone was installed at the Springer premises. Although there were at that time six daily postal deliveries and the pneumatic tube dispatches between post offices were available for private use, the telephone greatly facilitated the many existing contacts with ministries and industries in Berlin. The first typewriter was acquired in 1896. It was used most of all for contracts but increasingly also for correspondence. Copies still had to be made with the copying press (purchased in 1860). Carbon paper came to be used in Germany only after the First World War.

Author Contracts and Royalties

Toth ulius Springer made formal contracts only for larger projects, otherwise an agreement by letter was enough for him. But because of its growing contacts with official bodies and societies, in 1879 the firm felt it must exchange formal contracts in all cases. Contracts with organisations required revenue stamps for 
up to 50 mark, checked and cancelled by the Royal Prussian Stamp Distributor, a practice not used for contracts with private persons until the autumn of 1899 . This additional procedure was not undertaken without special cause. These contracts all had as their basis a printed standardised form containing a number of variants which were corrected or added to by the owner before the author was sent a copy of the proposal. The preprinted standardised form was used so that the owner would not forget to include an important clause from a quickly concluded contract.

All contracts were numbered consecutively and were then stored in order. Those written until 1923 have been preserved almost without exception - over 3,0oo in all. Those written since then were lost in the Second World War, after having been stored in an Austrian mine.

Until the end of the 1870 s payment to authors was always according to the expected or actual number of sheets of the planned book, using 1000 copies as standard. Around 1860 Springer-Verlag paid 8-10 taler per sheet of large octavo format, 40-50 mark around 1880, and before World War I about 70 mark. These are average figures: the payment per sheet was obviously lower for smaller formats with less text on a page. Additions or subtractions were common for print runs of more or fewer than 1000 copies.

Payment was made after the book had been produced, i.e. independently of the number of books sold. The publisher's risk was high for a book that would be difficult to sell, while the author received a known amount for his work.

From 1880 Springer-Verlag started to propose an alternative payment of sharing in the revenue after the publisher's costs had been covered. ${ }^{34}$ Apart from technical production, these costs included $15 \%$ for direct expenses (advertisements, dispatch etc.). What remained (if any) was usually divided in half. For highly successful books or specially favoured authors the firm was satisfied with keeping one third (see p.114).

The author received nothing if a book was a failure for the publisher and its costs were not covered by revenue. But when the sales were good or a reprint was required this form of contract was much better for the author than being paid by the sheet. This form of contract was always proposed by SpringerVerlag when there was no good way of predicting the likely sales or the ultimate amount of text or illustrations was uncertain. Such a contract was advantageous to the publisher because 
35

Verlagsbuchhandlung von Julius Springer in Berlin.

\section{Verlaces Vertuag.}

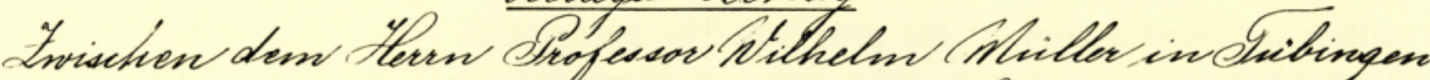

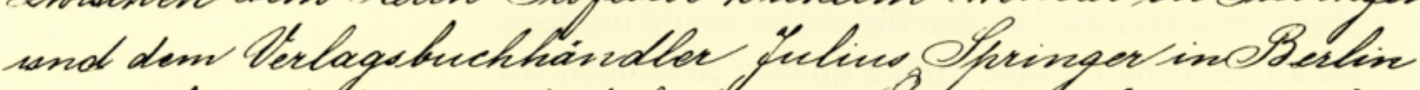
sind begighich dev alliahulich van Gusteren hevarequebenen,

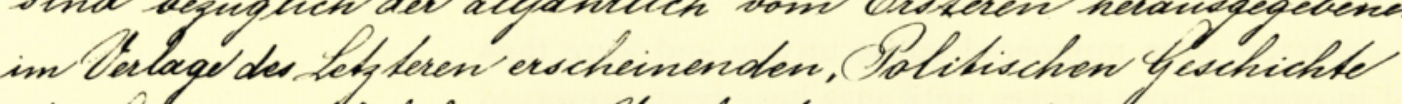

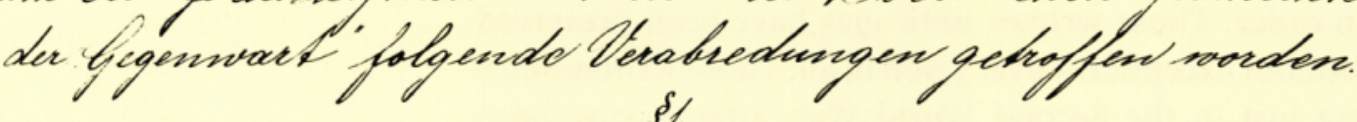

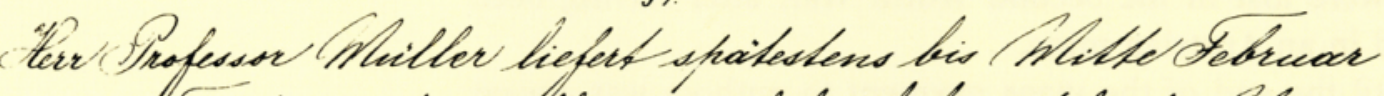

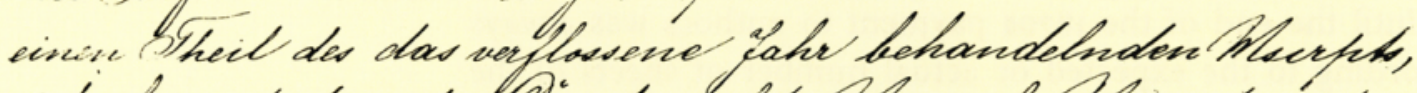

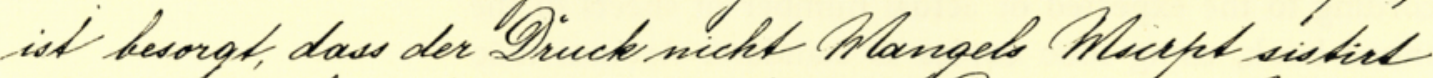

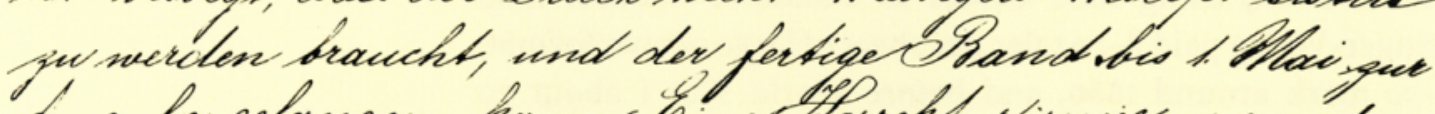

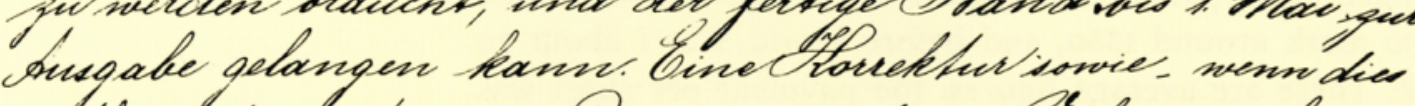

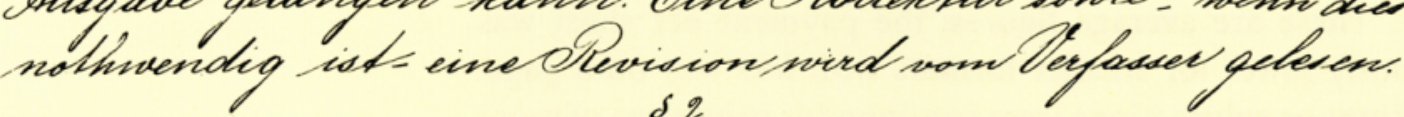

\section{s.}

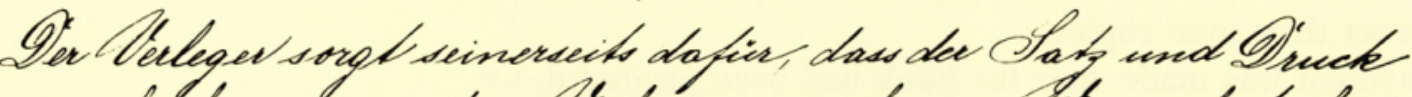

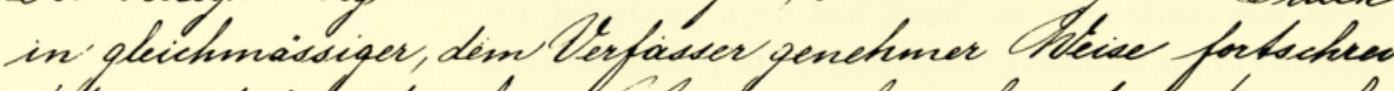

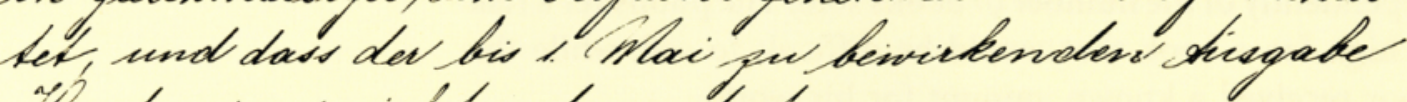
lindernise nicht entgegenteren.

$$
\delta^{\prime} 3 .
$$

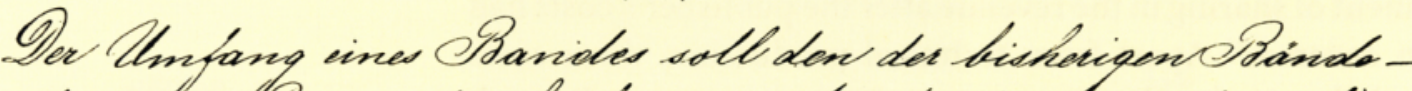

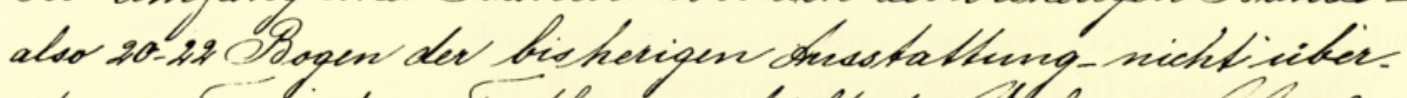

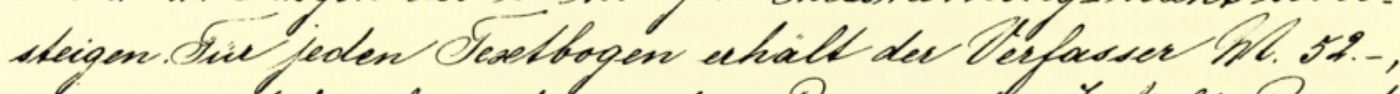

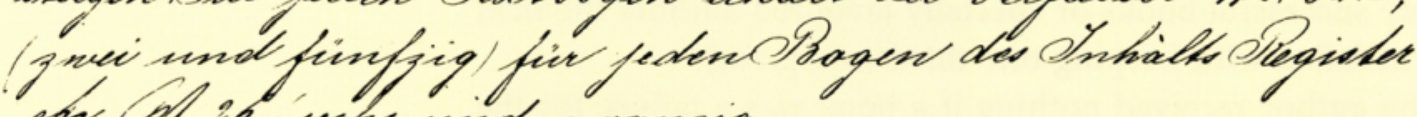
ese. Ml. is wecho wind prompig.

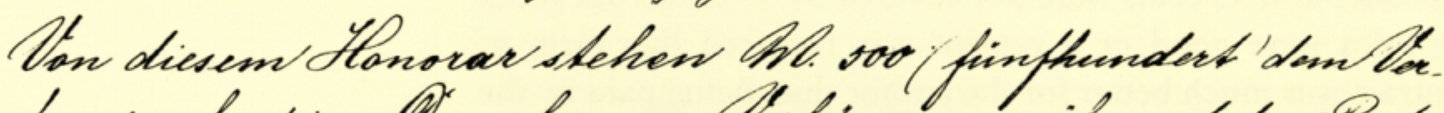

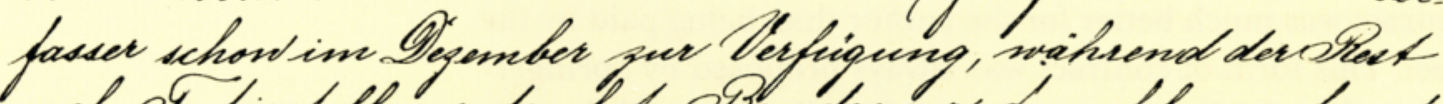

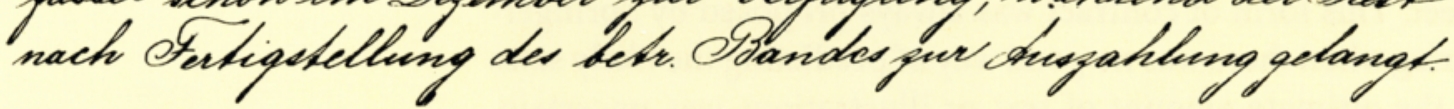


special wishes by the author (e.g. regarding illustrations) or high correction costs affected author and publisher equally. Every further expense that was incurred after the list price had been fixed reduced the amount available to both.

The proportion of "sharing" contracts, at first criticised by many authors as obscure, steadily increased. Authors were usually persuaded when an example was calculated before them. In 1890 , ten years after it was introduced, this type of contract made up only $14 \%$ of all contracts, but by 1910 the proportion had risen to $36 \%$ [FS: 34 ]. Incidentally, this form of contract was quite usual at the time for the pharmaceutical industry. Thus Paul Ehrlich agreed to " $50 \%$ of the attained profits" for his diphtheria antitoxin manufactured by Farbwerke Hoechst [BÄUMLER: 107]. When, later, Ehrlich published with SpringerVerlag he was fully familiar with this mode of sharing.

Occasionally an author would also be responsible for all production costs and set the list price, as did Werner von Siemens with his Lebenserinnerungen (Memoirs) (see p. 109).

All in all the comment is justified that a scientific publisher like Springer paid to the author amounts at least the equal of those for trade books: it is merely that the form of payment differed. A percentage share of the list became customary in scientific publishing only during the inflation of the 1920 s (further discussed on p. 241).

$\mathrm{I}$ n January 1904 Ferdinand and Fritz Springer appointed their sons, Ferdinand jr. and Julius jr., to their staff. Their fathers were then only 58 and 54 years and will hardly have been thinking of retirement. But the question of what would happen to the firm if one of them died prematurely had concerned the brothers in earlier years. It was, therefore, agreed to take the oldest sons into the firm as co-owners at an appropriate time and after they had become familiar with the work. But there may have been other reasons why the cousins joined the firm when they were only 23 and 24 years of age, respectively. As Fritz Springer put it, looking back [FS: $32 \mathrm{f}$.], he and his brother had made "the mistake of wanting to do too much themselves, even when the business had grown to a larger size. Neither of us understood that we had to bring in people who could work on their own; perhaps we also lacked the trust that delegated work would be done according to our wishes." As, in the ever expanding firm, it was especially the directorial functions that needed greater
149 (See opposite page.) Contract with Professor Wilhelm Müller (1820-1892), a senior teacher at the classical secondary school in Tübingen. From 1867 until his death he wrote a political chronicle $(\mathrm{Po}-$ litische Geschichte der Gegenwart (Political History of the Present)), continued by Karl Wippermann after 1892. Springer also published four other historical books by Müller. This was the first time that the publishing house specified contractually the rights and duties of author and publisher. 
150 The Joachimsthalsche Gymnasium (Classical Secondary School) in the Burgstrasse, Berlin, where both Ferdinand and Julius Springer were pupils. Several of its teachers were also authors of Springer schoolbooks (e.g. Carl Franke, Hermann Heller and Friedrich Gustav Kießling).

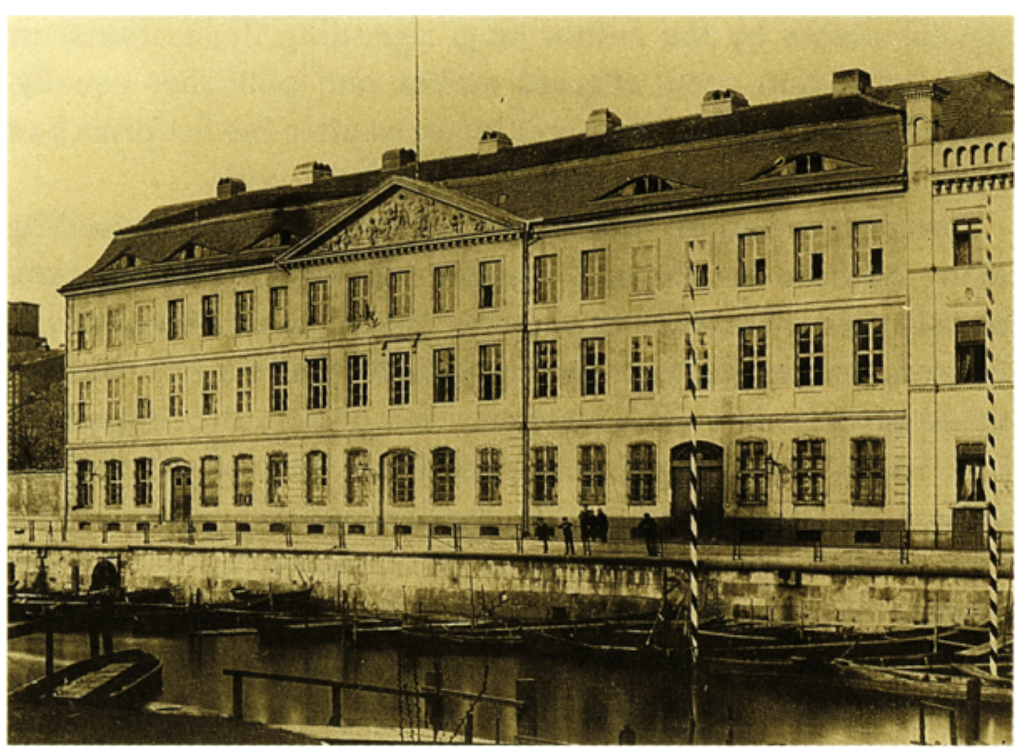

strengthening, the two fathers decided to give their sons the responsibility very early.

Ferdinand Springer's oldest son, also named Ferdinand, was born on August 29,1881. He showed an interest in the natural sciences from boyhood, and at seven years of age he began to write a book on butterflies, to the derision of his siblings. When he was barely ten years old he was sent to the Schnepfenthal Educational Institute ${ }^{35}$, which had been established in Walthershausen (near Gotha) by Pastor Christian Gotthilf Salzmann in 1784. Apart from minor reforms the school was still being guided by Salzmann's principles. Nature study, gardening and sports were especially stressed. As classes had only 14 pupils, teaching could largely take account of each pupil's special talents, inclinations and abilities.

As the Institute only went up to the third grade Ferdinand transferred to the Joachimsthalsche Gymnasium (classical secondary school). After graduating from the school in 1899 he went to Oxford for three terms where he studied art, "without giving up my own views, but showing understanding and respect for other opinions and views." In his report of 1952 [LB] (see p.162 ff.) he confessed: "No part of my life has contributed to widening my horizons to the same degree." At that time Ferdinand was still considering going into the diplomatic service.

On August 1, 1900 he became a bookselling apprentice at Schmidt \& Francke in Berne where his father had worked as assistant from 1868 to 1870 (when it was still called Dalp'sche 
Buchhandlung). Although the shop's focus was on belletristics, there were also books in medicine, the natural sciences and forestry. In Berne he got to know the physiologist Lean Asher who managed on their Sunday meetings to awaken in him an enthusiasm for medical research. For Ferdinand the friendship that developed with Asher was of decisive significance by generating a special interest in medicine for which Asher soon became his adviser. In the autumn of 1902, at the end of his apprenticeship, he worked for a few months as a volunteer at the Berlin printing plant of H.S. Hermann and afterwards did his one-year military service in Wiesbaden.

Julius Springer jr., oldest son of Fritz Springer, was born on April 29, 1880. Like his cousin Ferdinand he went to the Joachimsthalsche Gymnasium and from there, after graduation, for six months to England. His training in the book trade began on October 1, 1898, at first at the bookshop of Röhrscheid \& Ebbecke in Bonn for one year and then in Stuttgart with Konrad Wittwer, who had specialised in technical-scientific literature and had good connections to the local Technical College and the growing industry in the Stuttgart area. After Julius' one-year military service he went to work for over a year with Karl J. Trübner, a publisher in Strassburg who had founded his firm in 1872 and had concentrated on the humanities, especially linguistics [LÜDTKE]. Trübner, who was a friend of both father and uncle, had himself suggested many of the books which he then published, e.g. Minerva. Jahrbuch der gelehrten Welt (Minerva, Yearbook of the Learned World). With his uncle Nicolaus' firm, who had an antiquariat in London, Trübner had managed to bring the Manesse Song Manuscript to Germany in a multilateral exchange: it has been kept in Heidelberg since $1888 . *$

For his final period of training for his future role as publisher Julius went as volunteer to Pierersche Hofbuchdruckerei (Pierer's Court Printing Works) in Altenburg where his father had learned about the technical aspects of book production in 1878 . Like his father, he became an expert in all questions of book

\footnotetext{
* The Manessian Manuscript is a collection of Middle High German Minnesongs, consisting of about 7000 verses from over 130 Minnesingers. It was once thought (perhaps wrongly) to have been assembled by Rüdiger Manesse and his son (hence the designation). It first came to Heidelberg in 1607 but was later taken to Paris among spoils of war during the 30-Year War, before being returned to Heidelberg by Karl J. Trübner in a complex exchange of manuscripts. It is a unique source of Middle High German lyrics.
}

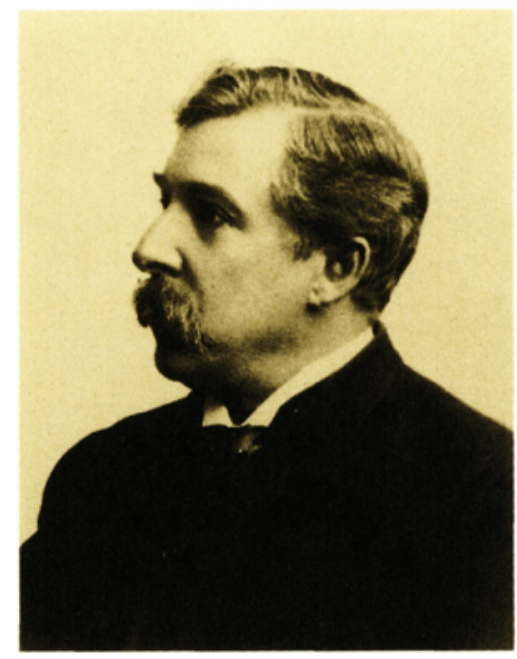

151 Karl Trübner (1846-19o7), publisher. Julius Springer first met him in 1872 when he took part in the opening of the German University in Straßburg, where Trübner had just founded his publishing house. Julius Springer apprenticed with him in 1902 to work in a bookshop oriented towards the humanities. 
production. His experienced eye for errors in composition was famous and feared.

In a circular dated December 24, 1906 the two fathers announced to the book trade that their sons had joined them as co-owners of Springer-Verlag. In similarly worded and jointly signed letters they informed their sons of this step, adding their hope that "the greater responsibility that comes with this greater independence and the greater duties may never be a burden to you but always only a pleasure; and may they stimulate you to keep at its present height the business that your grandfather founded and that had been brought to a fine flowering by your fathers, and to lead it forward to new paths and thus disarm the widely held view that the third generation regresses!" [Hö$\operatorname{VEL}(1): 259]$.

Three days later Ferdinand Springer the elder died.

Ferdinand Springer's Last Weeks

152 Ferdinand Springer, towards the end of his life.

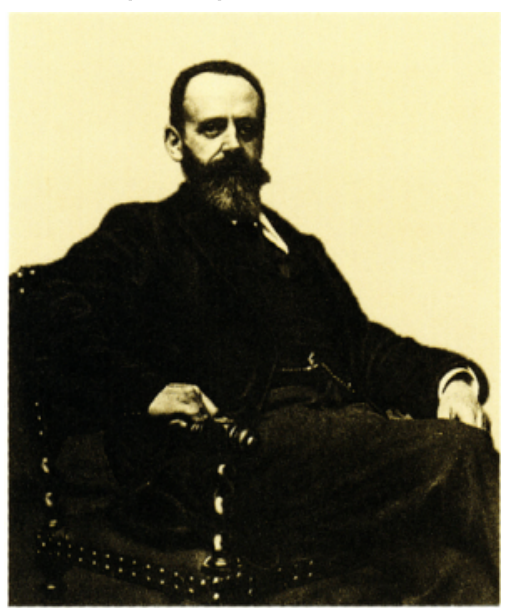

$\mathrm{O}$ n November 13, 1906 Ferdinand Springer had taken part in the celebration to mark the laying of the foundation stone of the Deutsches Museum in the Wittelsbacher Palais in Munich. A few months later Springer-Verlag published the opening address given by Adolf Slaby about Otto von Guericke. After his return Ferdinand complained of continual thirst, which had become worse on the journey home. His family doctor diagnosed diabetes. With his lively temperament and the inability to take care of his health, which he had always shown, the illness was worrying. However, when he visited his brother on December 3, for his birthday, he was still in high spirits and, like his father tending to tease and mock, he joked about his state [FS:39]. But a steady deterioration began the next day and from the middle of December onwards he no longer went to his office. It was probably at that time that the two brothers decided to take in their sons as co-owners. Ferdinand died on December 27, at 3 o'clock in the afternoon and on December 30 was buried in the cemetery of the Matthäi Church. ${ }^{36}$ The obituary notices were sent to his business friends together with the circular announcing the appointment of son and nephew as co-owners.

Hundreds of letters and cards of condolence, from friends, authors, publishers, editors and colleagues, are evidence of the shock with which the news of his unexpected and quick death at the age of only 61 years was received. They praised the judge of human character, the keen observer, the conciliatory publisher, his openness and the certainty with which he would quickly get 
to the kernel of a problem and make practical proposals for its solution. Respectful obituaries were written by the editors of the journals he had founded. A long-standing staff-member of Springer-Verlag wrote to his family:

Ferdinand Springer was the kindest chief, friendly and just. Everyone who was worried found a receptive ear with him and an understanding reception for his affairs, and often he would involve himself in a person's financial problems by advising, helping and straightening them out. His always dignified manner... was not without influence on the spirit of the Springer House and the whole tone of its staff with each other.

It was the open, free, polite manner in which he treated them and which never had anything of condescension or feeling of superiority that won him the hearts of his staff in such high measure - and yet everyone felt the superiority of his personality, and it was always understood that everyone submitted to it.

Ferdinand Springer made great demands on his personnel and demanded untiring and punctual fulfilment of duties, the same as he had demanded of himself all his life and through which he became an example. Disorderliness, lack of punctuality and carelessness or even indifference were not tolerated by him. Just as he never postponed till tomorrow what he could do today, just as he always took up at once everything that came to him and dealt with it with the promptness that was so characteristic of him, in the same way he asked quickness, precision and order of all of his staff. He hated any postponement and temporisation. Some people may not always find it very comfortable to have a chief who never forgets, whose eager eyes miss nothing and who "finds out everything," but no one could withhold from him an unconditional high respect and everyone who was allowed to work for a while under his direction and to learn in the exemplary business of the Springer firm is grateful to him [FRANCKE: XVI].

A few lines will make clear the development of SpringerVerlag in the three decades, 1877-1906, during which Ferdinand and Fritz Springer directed the firm. In 1877 there were just four employees, by 1906 the number had risen to 65 . In the last decade of Julius Springer's publishing activity an average of 37 titles and four journals were published annually. By comparison, in the last decade of Ferdinand Springer's activity the average was 120 book titles and 30 journals. But it would be too simple just to compare numbers and would look like giving marks. This would be quite unfair to the founder who gave up a great deal during the last decade of his life to his honorary positions in the Börsenverein and the Berlin Town Council. 


\begin{tabular}{|l|cc|cc|cc|cc|}
\hline & \multicolumn{2}{|c|}{$1868-1877$} & \multicolumn{2}{|c|}{$1878-1887$} & \multicolumn{2}{|c|}{$1888-1897$} & \multicolumn{2}{c|}{$1898-1906$} \\
\cline { 2 - 9 } & Titles & Rank & Titles & Rank & Titles & Rank & Titles & Rank \\
\hline Agriculture and forestry & 88 & 1. & 160 & 1. & 126 & 4. & 95 & 5. \\
Law, political science, & 68 & 2. & 128 & 2. & 147 & 3. & 186 & 2. \\
commerce, trade & & & & & & & & \\
Philosophy, theology, & 66 & 3. & 115 & 3. & 104 & 5. & 66 & 7. \\
art, schoolbooks & 34 & 4. & 96 & 5. & 158 & 2. & 147 & 3. \\
Natural sciences & 33 & 5. & 30 & 7. & 27 & 8. & 15 & 9. \\
History, current affairs & 31 & 6. & 43 & 6. & 77 & 7. & 76 & 6. \\
Pharmacy & 28 & 7. & 18 & 8. & 24 & 9. & 23 & 8. \\
Various & 24 & 8. & 100 & 4. & 174 & 1. & 347 & 1. \\
Engineering & 1 & 9. & 11 & 9. & 98 & 6. & 115 & 4. \\
Medicine & 373 & & 701 & & 935 & & 1070 & \\
\hline & 37 & & 70 & & 94 & & 119 & \\
\hline Annual average of titles & & & & & & & \\
\hline
\end{tabular}

List 6 Title production, $1868-1906$
On the other hand, the strengthening of the business's management by Fritz decisively contributed to the firm's progress.

But one should also take into account the general development of book and journal production in this period (List above). In 1875 (no figures have survived for 1877) about 10,00o books and 2000 journals were published in Germany. In 1906 there were 24,500 books $(+145 \%)$ and 5800 journals $(+190 \%)$. Thus the whole book market had greatly expanded: but the growth of Springer-Verlag was considerably above the average. The German Empire had developed from an agricultural to an industrial state. It was Ferdinand Springer's great service, together with his brother Fritz, not only to have followed this trend but in many areas actually to have hastened ahead of it.

A statistical evaluation of the Springer Catalogue ${ }^{37}$, given in List 6 above, demonstrates the new structure of the programme. The number of published titles is merely one measure of growth: print-run, size, price, turnover and profitability cannot be taken into account here any more than these items as they relate to journals, because too few representative data are available. Nonetheless, the number of annually published books is an index of the growth and the change in the orientation of the programme. 
It is not difficult to see that the areas of engineering and medicine had gradually grown during the three decades. A decline is to be noted in the humanities (theology, philosophy, music, art, education), but also in forestry sciences. Pharmacy and all subjects relating to public affairs (law, economics, trade, transport etc.) remained relatively stable. A somewhat generalised summary shows that the theoretical and applied natural sciences made up $64.0 \%$ of production between 1898 and 1906 , compared with $24.1 \%$ in the last decade of Julius Springer's activity (1868-1877). Compared with the 1868-1877 period, the proportion of books in the humanities had correspondingly been much reduced. It was from this base that the new owners now further developed the firm.
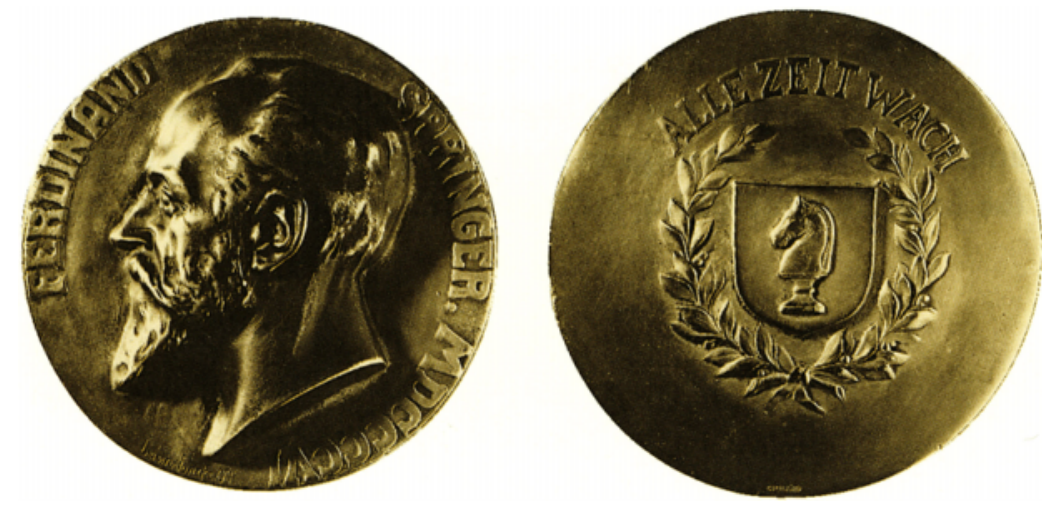

153 Medallion in memory of Ferdinand Springer, by Arthur LewinFuncke, 1907. (See Fig. 367). 